\title{
APLICAÇÃO FOLIAR DE FÓSFORO, METABOLISMO FOTOSSINTÉTICO E PRODUTIVIDADE DO FEIJOEIRO COMUM SOB DÉFICIT HÍDRICO
}

\section{MAURO GUIDA DOS SANTOS}

\author{
Tese apresentada à Escola Superior de Agricultura \\ "Luiz de Queiroz", Universidade de São Paulo, para \\ obtenção do título de Doutor em Agronomia, Área de \\ Concentração: Fitotecnia.
}

P I R A C I C A B A

Estado de São Paulo - Brasil

Janeiro - 2005 


\title{
APLICAÇÃO FOLIAR DE FÓSFORO, METABOLISMO FOTOSSINTÉTICO E PRODUTIVIDADE DO FEIJOEIRO COMUM SOB DÉFICIT HÍDRICO
}

\author{
MAURO GUIDA DOS SANTOS \\ Engenheiro Agrônomo
}

Orientador: Prof. Dr. RICARDO FERRAZ DE OLIVEIRA

Tese apresentada à Escola Superior de Agricultura

"Luiz de Queiroz", Universidade de São Paulo, para obtenção do título de Doutor em Agronomia, Área de Concentração: Fitotecnia.

P I R A C I C A B A

Estado de São Paulo - Brasil

Janeiro - 2005 
Dados Internacionais de Catalogação na Publicação (CIP) DIVISÃO DE BIBLIOTECA E DOCUMENTAÇÃO - ESALQIUSP

Santos, Mauro Guida dos

Aplicação foliar de fósforo, metabolismo fotossintético e produtividade do feijoeiro comum sob déficit hídrico / Mauro Guida dos Santos. - - Piracicaba, 2005.

$74 \mathrm{p}$.

Tese (Doutorado) - - Escola Superior de Agricultura Luiz de Queiroz, 2005. Bibliografia.

1. Adubação foliar 2. Balanço hídrico 3. Feijão 4. Fisiologia vegetal 5. Fósforo 6. Fotossíntese 7. Genótipo 8. Relação solo-água-planta-atmosfera 9. Tolerância a seca I. Título

CDD 635.652 
À minha Família...

...meus pais Lenir Guida dos Santos e Maurício dos Santos...

...minhas irmãs Maria José e Márcia...

...que sempre me apoiaram...

DEDICO. 


\section{AGRADECIMENTOS}

À Escola Superior de Agricultura “Luiz de Queiroz”, Universidade de São Paulo, pela oportunidade concedida.

A CAPES, pela bolsa de estudos.

Aos Professores Carlos Pimentel, Ricardo Ferraz de Oliveira e Durval Dourado Neto por me ajudarem no início do curso.

Nas linhas seguintes seria injusto dizer que eu conseguiria agradecer a todos aqueles que me ajudaram direta ou indiretamente nesta caminhada. No entanto, nos últimos tempos (os mais difíceis até agora) a colaboração de uns e a amizade de outros tem sido fundamental para a continuidade desta caminhada. Assim, não poderia deixar de lembrar da boa convivência dentro da república, com pessoas de primeiríssima qualidade como o Simão, o Alessandro, o Paulo e os que por lá passaram neste período, o Tobias, o Alexandre e o Juliano.

No ambiente externo quer seja no lazer ou no trabalho a presença e ou colaboração direta de algumas pessoas foi fundamental, assim além dos sempre presentes já acima citados, devo lembrar da Jeanedy, do Alexandre, do Pequeno, do Tirolês, da Luciana, da Míriam, do Carlos, do Gustavo, do Rafael, da Ilana, da Camila, da Paula, do Marcelo e do Oscar. Além dos colegas de curso, pela convivência sadia apesar do grande volume de trabalho.

A Valesca pela companhia e incentivo no último ano, que Deus te abençoe!!!

A todos sou muito grato por tudo que fizeram, estarei sempre torcendo pelo sucesso de cada um de vocês, e que Deus possa retribuir o bem que fizeram em dobro. 


\section{SUMÁRIO}

Página

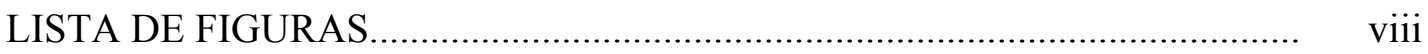

LISTA DE TABELAS................................................................................ xi

LISTA DE SÍMBOLOS....................................................................... xiii

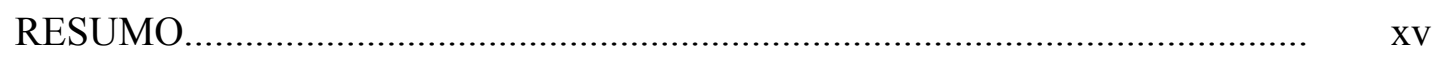

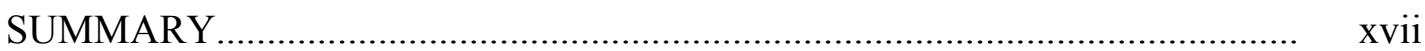

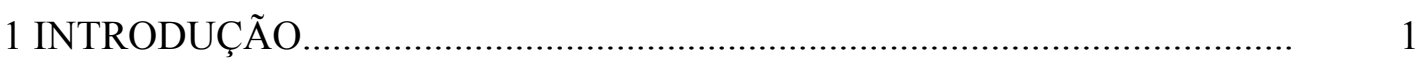

2 REVISÃO DE LITERATURA.............................................................. 4

2.1 Aspectos gerais sobre a cultura do feijoeiro (Phaseolus vulgaris).................. 4

2.2 Efeitos do déficit hídrico na cultura do feijoeiro............................................ 5

2.3 Deficiência hídrica e atividade fotossintética..................................................... 6

2.4 Principais mecanismos de tolerância à seca no feijoeiro................................... 7

2.5 Disponibilidade no solo e eficiência do feijoeiro na absorção de fósforo........ 8

2.6 Regulação da fotossíntese pela disponibilidade de Pi citoplasmático............. 9

3 Aplicação foliar de fósforo e resposta do metabolismo fotossintético ao déficit hídrico em Phaseolus vulgaris.............................................................. 12

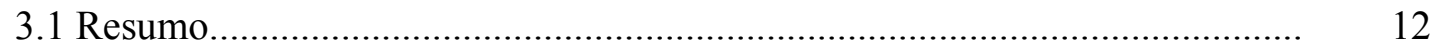

3.2 Summary ........................................................ 12

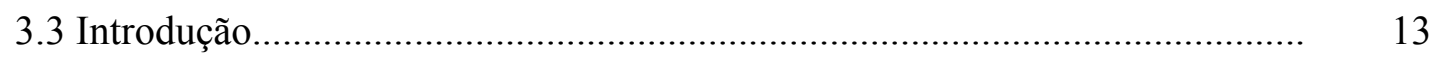

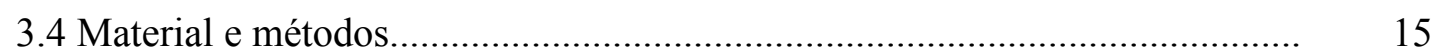

3.4.1 Material vegetal e condições de crescimento.............................................. 15

3.4.2 Suplementação de fósforo e déficit hídrico............................................... 16

3.4.3 Avaliação do status hídrico das plantas.................................................... 16

3.4.4 Medidas de trocas gasosas...................................................................... 16 
3.4.5 Componentes da produção.

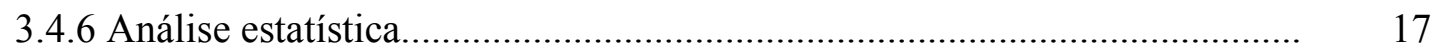

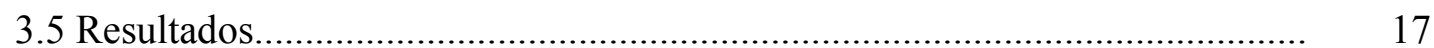

3.5.1 Relações hídricas e trocas gasosas sob suplementação extra de fósforo e déficit hídrico

3.5.2 Os efeitos da suplementação extra de fósforo e do déficit hídrico moderado nos componentes de produção.

3.6 Discussão.

4 Resposta das trocas gasosas e da produtividade à aplicação foliar de fósforo em Phaseolus vulgaris sob seca.

4.1 Resumo.

4.2 Summary.

4.3 Introdução

4.4 Material e métodos.

4.4.1 Material vegetal e condições de crescimento.

4.4.2 Os tratamentos de déficit hídrico e o suprimento foliar de fósforo..

4.4.3 Suprimento de fósforo e conteúdo foliar.

4.4.4 Trocas gasosas, potencial da água na folha e componentes de produção.....

4.4.5 Análise estatística.

4.5 Resultados

4.5.1 Experimento I: Suprimento foliar de fósforo: trocas gasosas e distribuição de massa seca.

4.5.2 Experimento II: suprimento foliar de fósforo em diferentes épocas............ 35

4.5.3 Experimento III: concentrações diferentes no suprimento foliar de fósforo 36

4.6 Discussão...................................................................................... 42

5 Aplicação foliar de fósforo, trocas gasosas e fluorescência da clorofila, em genótipos de feijoeiro comum submetidos a um déficit hídrico moderado......

5.1 Resumo. 


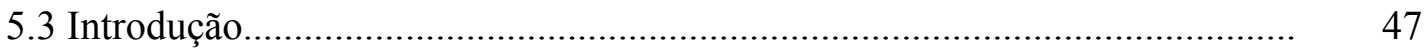

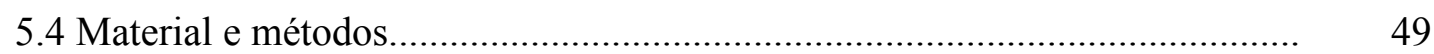

5.4.1 Material vegetal e condições de crescimento.............................................. 49

5.4.2 Aplicação foliar de fósforo...................................................................... $\quad 50$

5.4.3 Avaliação do potencial da água foliar..................................................... $\quad 50$

5.4.4 Trocas gasosas foliar.......................................................................... $\quad 50$

5.4.5 Liberação de $\mathrm{O}_{2}$ fotossintético............................................................. 51

5.4.6 Fluorescência da clorofila a....................................................................... 51

5.4.7 Componentes da produção.................................................................... 52

5.4.8 Análise estatística................................................................................ 52

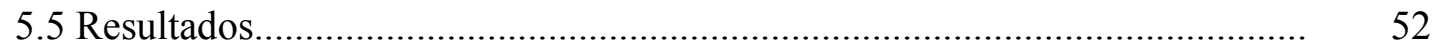

5.5.1 Potencial da água da folha........................................................................ 52

5.5.2 Efeito da seca e da aplicação de Pi foliar sobre as trocas gasosas e a

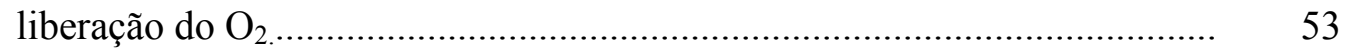

5.5.3 Deficiência hídrica, aplicação de Pi e fluorescência da clorofila................. 56

5.5.4 Efeito da seca e do suprimento de Pi sobre os componentes de produção... 57

5.6 Discussão................................................................................................ 58

6 CONCLUSÕES GERAIS......................................................................... 62

REFERÊNCIAS BIBLIOGRÁFICAS............................................................ 63 


\section{LISTA DE FIGURAS}

Página

\section{APLICAÇÃO FOLIAR DE FÓSFORO E RESPOSTA DO METABOLISMO FOTOSSINTÉTICO AO DÉFICIT HÍDRICO EM}

Phaseolus vulgaris

1 Curso diário da assimilação de $\mathrm{CO}_{2}(A)$ e condutância estomática $\left(g_{s}\right)$ em plantas, com suprimento de Pi foliar (círculo fechado) e sem Pi (círculo aberto), dos genótipos de feijoeiro Carioca (A, B) e Ouro Negro (C, D) um dia após o suprimento de Pi foliar. Os dados são valores médios \pm erro padrão $n=3$ ).

2 Potencial da água na folha $\left(\Psi_{f}\right)$ em plantas, com suprimento de Pi foliar (símbolos fechados) e sem Pi (símbolos abertos), dos genótipos de feijoeiro Carioca (círculos) e Ouro Negro (triângulos), submetidos a três dias de déficit hídrico e dois dias de reidratação. A irrigação foi suspensa após dois dias da aplicação de Pi foliar. As medidas foram realizadas antes do amanhecer. Os dados são valores médios \pm erro padrão $(n=3)$

3 Condutância estomática $\left(g_{s}\right)$ em plantas, com suprimento de Pi foliar (círculo fechado) e sem Pi (círculo aberto), dos genótipos de feijoeiro comum, Carioca (A, B, C) e Ouro Negro (D, E, F), submetidos a três dias de déficit hídrico e dois dias de reidratação. A irrigação foi suspensa após dois dias da aplicação de Pi foliar. As medidas foram realizadas às 09:00 (A, D), 12:00 $(\mathrm{B}, \mathrm{E})$, e 15:00 h $(\mathrm{C}, \mathrm{F})$. A temperatura média diária variou de 28,0 a 28,9 ${ }^{\circ} \mathrm{C}$. Os dados são valores médios \pm erro padrão $(n=3)$.

4 Assimilação de $\mathrm{CO}_{2}(A)$ em plantas, com suprimento de Pi foliar (círculo 
fechado) e sem Pi (círculo aberto), dos genótipos de feijoeiro comum, Carioca (A, B, C) e Ouro Negro (D, E, F), submetidos a três dias de déficit hídrico e dois dias de reidratação. A irrigação foi suspensa após dois dias da aplicação de Pi foliar. As medidas foram realizadas às 09:00 (A, D), 12:00 $(\mathrm{B}, \mathrm{E})$, e 15:00 h (C, F). A temperatura média diária variou de 28,0 a 28,9 ${ }^{\circ} \mathrm{C}$. Os dados são valores médios \pm erro padrão $(n=3)$

5 Eficiência intrínseca do uso da água (EIUA) ao meio dia $(12: 00 \mathrm{~h}) \mathrm{em}$ plantas, com suprimento de Pi foliar (círculo fechado) e sem Pi (círculo aberto), dos genótipos de feijoeiro comum, Carioca (A) e Ouro Negro (B), submetidos a três dias de déficit hídrico e dois dias de reidratação. A irrigação foi suspensa após dois dias da aplicação de Pi foliar. Os dados são valores médios da relação $A / g s \pm$ erro padrão $(n=3)$

RESPOSTA DAS TROCAS GASOSAS E DA PRODUTIVIDADE À APLICAÇÃO FOLIAR DE FÓSFORO EM Phaseolus vulgaris SOB SECA.

1 Taxa de assimilação líquida de $\mathrm{CO}_{2}(A)$ e comdutância estomática $\left(g_{s}\right)$ do genótipo Carioca submetido a onze dias de déficit hídrico. As folhas foram pulverizadas com $10 \mathrm{~g} \mathrm{Pi} \mathrm{L}^{-1}$ (Pi10, símbolos fechados) ou 2,64 $\mathrm{g} \mathrm{N} \mathrm{L}^{-1}$ (N10, símbolos abertos) cinco dias antes da suspensão da irrigação, em plantas controle (triângulos), irrigadas continuamente, e em plantas sob seca (círculos). As medidas foram realizadas entre as 09:00-10:30 h. Cada ponto representa o valor médio \pm erro padrão $(n=3)$

2 Área foliar, massa seca de ramos, folhas e raízes do genótipo de feijoeiro (Carioca), submetido a onze dias de déficit hídrico, no estádio de préfloração. As folhas foram pulverizadas com $10 \mathrm{~g} \mathrm{Pi} \mathrm{L}^{-1}$ (Pi10) ou 2,64 g N $\mathrm{L}^{-1}$ (N10) cinco dias antes da suspensão da irrigação. Cada barra representa o valor médio \pm erro padrão $(n=3)$

3 Valores do potencial de água na folha ( $\left.\Psi_{f}\right)$ antes do amanhecer, em genótipos de feijoeiro, A320 (A), Carioca (B), e Ouro Negro (C), 
submetidos a onze dias de déficit hídrico, no estádio de pré-floração, e três dias de reidratação. As folhas foram pulverizadas com $10 \mathrm{~g} \mathrm{P} \mathrm{L}^{-1}$ (Pi10, círculo fechado) ou 2,64 $\mathrm{g} \mathrm{N} \mathrm{L}^{-1}$ (N10, círculo aberto). Cada ponto representa o valor médio \pm erro padrão $(n=3)$..

4 Taxa de assimilação de $\mathrm{CO}_{2}(A)$ de genótipos de feijoeiro, A320 (a-c), Carioca (d-f), e Ouro Negro (g-i), submetidos a onze dias de déficit hídrico e três dias de reidratação. As folhas foram pulverizadas com $10 \mathrm{~g} \mathrm{P} \mathrm{L}^{-1}$ (Pi10, círculo fechado) ou 2,64 $\mathrm{g} \mathrm{N} \mathrm{L}^{-1}$ (N10, círculo aberto), em diferentes épocas: cinco dias antes da suspensão da irrigação $(A, D, G)$; no $6^{\circ}(B, E$, $\mathrm{H})$ e no $11^{\circ}(\mathrm{C}, \mathrm{F}, \mathrm{I})$ dias de déficit hídrico. A temperatura média diária variou de 16,5 a $26,0{ }^{\circ} \mathrm{C}$. Cada ponto representa a média \pm erro padrão $(n=3)$

5 Valores do potencial de água da folha antes do amanhecer ( $\left.\Psi_{f}\right)$, do genótipo Carioca submetido a dez dias de déficit hídrico e dois dias de reidratação. As folhas foram pulverizadas com $10 \mathrm{~g} \mathrm{P} \mathrm{L}^{-1}$ (Pi10, círculos abertos) ou 20 $\mathrm{g} \mathrm{P} \mathrm{L}^{-1}$ (Pi20, círculos fechados) cinco dias antes do início da seca. Cada ponto representa a média \pm erro padrão $(n=3)$.

6 Taxa de assimilação de $\mathrm{CO}_{2}(A)$ do genótipo de feijoeiro Carioca submetido a dez dias de déficit hídrico e dois dias de reidratação. As folhas foram pulverizadas com $10 \mathrm{~g} \mathrm{P} \mathrm{L}^{-1}$ (Pi10, círculos fechados em A-C) ou 2,64 g N $\mathrm{L}^{-1}$ (N10, círculos abertos em A-C); $20 \mathrm{~g} \mathrm{Pi} \mathrm{L}^{-1}$ (Pi20, círculos fechados, em D-F) ou 5,28 $\mathrm{g} \mathrm{N} \mathrm{L}^{-1}$ (N20, círculos abertos em D-F) cinco dias antes da suspensão da irrigação. As medidas foram realizadas entre 09:00-10:30 h (A, D), 12:00-13:30 h (B, E) e 15:00-16:30 h (C, F). A temperatura média diária variou de 18,8 a $22,8{ }^{\circ} \mathrm{C}$. Cada ponto representa a média \pm erro padrão $(\mathrm{n}=3)$.

APLICAÇÃO FOLIAR DE FÓSFORO, TROCAS GASOSAS E FLUORESCÊNCIA DA CLOROFILA, EM GENÓTIPOS DE FEIJOEIRO COMUM SUBMETIDOS A UM DÉFICIT HÍDRICO 
1 Taxa de assimilação de $\mathrm{CO}_{2}\left(A\right.$ em A, D), condutância estomática $\left(g_{s}\right.$ em B, E) e concentração de $\mathrm{CO}_{2}$ intercelular $\left(C_{i}\right.$ em $\left.\mathrm{C}, \mathrm{F}\right)$ dos genótipos de feijoeiro A320 (A, B, C) e Ouro Negro (D, E, F), sob déficit hídrico. As folhas foram pulverizadas com $10 \mathrm{~g} \mathrm{Pi} \mathrm{L}^{-1}$ (símbolos fechados) ou 2,64 $\mathrm{g} \mathrm{N}$ $\mathrm{L}^{-1}$ (símbolos abertos) dois dias antes da suspensão da irrigação. As plantas foram reidratadas após sete dias de seca. A temperatura média diária variou de 23 a $26,6{ }^{\circ} \mathrm{C}$. Cada ponto representa o valor médio \pm erro padrão $(n=3)$ 


\section{LISTA DE TABELAS}

Página

APLICAÇÃO FOLIAR DE FÓSFORO E RESPOSTA DO METABOLISMO FOTOSSINTÉTICO AO DÉFICIT HÍDRICO EM

Phaseolus vulgaris.

1 Componentes de produção dos genótipos de feijoeiro comum Carioca e Ouro Negro, para plantas hidratadas continuamente (controle) e para plantas submetidos a um déficit hídrico moderado (três dias de seca) no estádio de polinização, com e sem suprimento de Pi foliar, aplicado dois dias antes do déficit hídrico

RESPOSTA DAS TROCAS GASOSAS E DA PRODUTIVIDADE À APLICAÇÃO FOLIAR DE FÓSFORO EM Phaseolus vulgaris SOB SECA

1 Eficiência intrínseca do uso da água (EIUA), $\mathrm{A} / \mathrm{g}_{\mathrm{s}}\left[\mu \mathrm{mol} \mathrm{CO} \mathrm{CO}_{2}\left(\mathrm{~mol} \mathrm{H}_{2} \mathrm{O}\right)^{-1}\right]$, do genótipo de feijoeiro Carioca com suprimento foliar de $10 \mathrm{~g} \mathrm{Pi} \mathrm{L}^{-1}$ (Pi10) ou 20 g Pi L $^{-1}$ (Pi20), aplicados cinco dias antes da suspensão da irrigação. A EIUA foi calculada a partir das trocas gasosas medidas às 09:00-10:30, 12:00-13:30, e 15:00-16:30 h, dez dias após o início da seca (estresse máximo) e dois dias após a reidratação

2 Componentes de produção (número de vagens por planta e massa seca de sementes por planta) do genótipo de feijoeiro Carioca submetido a déficit hídrico, e suprido com $10 \mathrm{~g} \mathrm{Pi} \mathrm{L}^{-1}$ (Pi10), $20 \mathrm{~g} \mathrm{Pi} \mathrm{L}^{-1}$ (Pi20), 2,64 g N L-1 (N10) or 5,28 $\mathrm{g} \mathrm{N} \mathrm{L}^{-1}$ (N20) cinco dias antes da suspensão da irrigação..........

3 Conteúdo foliar de fósforo de genótipos de feijoeiro, sem suprimento foliar (controle) e com suprimento foliar de $10 \mathrm{~g} \mathrm{Pi} \mathrm{L}^{-1}$ (Pi10) ou de $20 \mathrm{~g} \mathrm{Pi} \mathrm{L}{ }^{-1}$ 
(Pi20), aplicados cinco dias antes da coleta das folhas (As amostras foram coletadas no primeiro dia de seca).

APLICAÇÃO FOLIAR DE FÓSFORO, TROCAS GASOSAS E FLUORESCÊNCIA DA CLOROFILA, EM GENÓTIPOS DE FEIJOEIRO COMUM SUBMETIDOS A UM DÉFICIT HÍDRICO MODERADO.

1 Liberação de $\mathrm{O}_{2}$ e potencial fotossintético $\left(\mu \mathrm{mol} \mathrm{m} \mathrm{m}^{-2} \mathrm{~s}^{-1}\right)(A c)$ de genótipos de feijoeiro A320 e Ouro Negro após sete dias de seca (máximo estresse) e após a reidratação (três dias após reidratar) em plantas pulverizadas com Pi foliar e não pulverizadas. As folhas supridas com Pi foram pulverizadas com $10 \mathrm{~g} \mathrm{P} \mathrm{L}^{-1}$ e as plantas sem Pi (controle) foram supridas com 2,64 g N $\mathrm{L}^{-1}$. Os valores são médias ( \pm e.p.) de três plantas

2 Taxa aparente de transporte de elétrons $\left(\mu \mathrm{mol} \mathrm{m} \mathrm{m}^{-2} \mathrm{~s}^{-1}\right)$ (ETR) e coeficiente de extinção não-fotoquímica da fluorescência (NPQ), de genótipos de feijoeiro A320 e Ouro Negro, após sete dias de seca (máximo estresse) e após a reidratação (três dias após reidratar) em plantas pulverizadas com Pi foliar e não pulverizadas. As folhas supridas com Pi foram pulverizadas com $10 \mathrm{~g} \mathrm{P} \mathrm{L}^{-1}$ e as plantas sem Pi (controle) foram supridas com 2,64 g N $\mathrm{L}^{-1}$. Os valores são médias ( \pm e.p.) de três plantas.

3 Componentes de produção (número de vagens e peso de sementes por planta) de genótipos de feijoeiro (A320 e Ouro Negro), submetidos ou não a sete dias de seca no estádio de polinização, com ou sem pulverização de Pi foliar. As folhas supridas com Pi foram pulverizadas com $10 \mathrm{~g} \mathrm{P} \mathrm{L}^{-1}$ e as plantas sem Pi (controle) foram supridas com 2,64 $\mathrm{g} \mathrm{N} \mathrm{L}^{-1}$. Os valores são médias ( \pm e.p.) de três plantas. 


\section{LISTA DE SÍMBOLOS}

A assimilação de $\mathrm{CO}_{2}\left(\mu \mathrm{mol} \mathrm{m} \mathrm{m}^{-2} \mathrm{~s}^{-1}\right)$

$\mathbf{A}_{\mathbf{C}}$ liberação de oxigênio fotossintético $\left(\mu \mathrm{mol} \mathrm{m} \mathrm{m}^{-2} \mathrm{~s}^{-1}\right)$

Ci concentração intercelular de $\mathrm{CO}_{2}\left(\mu \mathrm{L} \mathrm{L}^{-1}\right)$

DFFF densidade de fluxo de fótons fotossintéticos $\left(\mu \mathrm{mol} \mathrm{m} \mathrm{m}^{-2} \mathrm{~s}^{-1}\right)$

DPV déficit de pressão de vapor do ar $(\mathrm{kPa})$

ETR taxa aparente de transporte de elétrons $\left(\mu \mathrm{mol} \mathrm{m} \mathrm{m}^{-2} \mathrm{~s}^{-1}\right)$

Fo fluorescência basal após adaptação ao escuro (unid. rel.)

Fo $^{\prime} \quad$ fluorescência basal após excitação do fotossistema I (unid. rel.)

$\mathbf{F}_{\mathbf{m}}$ fluorescência máxima após adaptação ao escuro (unid. rel.)

$\mathbf{F}_{\mathbf{m}}{ }^{\prime} \quad$ fluorescência máxima na presença de luz (unid. rel.)

F fluorescência em estado de equilíbrio dinâmico, na presença de luz (unid. rel.)

$\mathbf{F}_{\mathbf{v}} \quad$ fluorescência variável após adaptação ao escuro (unid. rel.)

$\mathbf{F}_{\mathbf{v}} / \mathbf{F}_{\mathbf{m}}$ eficiência quântica potencial do fotossistema II

gs condutância estomática $\left(\mathrm{mol} \mathrm{m}^{-2} \mathrm{~s}^{-1}\right)$

NPQ coeficiente de extinção não-fotoquímica da fluorescência

qP coeficiente extinção fotoquímica da fluorescência

$\Delta \mathbf{F} / \mathbf{F}_{\mathbf{m}}$ ' eficiência quântica efetiva do fotossistema II 


\title{
APLICAÇÃO FOLIAR DE FÓSFORO, METABOLISMO FOTOSSINTÉTICO E PRODUTIVIDADE DO FEIJOEIRO COMUM SOB DÉFICIT HÍDRICO
}

\author{
Autor: MAURO GUIDA DOS SANTOS \\ Orientador: Prof. Dr. RICARDO FERRAZ DE OLIVEIRA
}

\section{RESUMO}

Os efeitos da aplicação foliar de fósforo (Pi) na condutância estomática $\left(g_{s}\right)$ e na fotossíntese $(A)$, foram avaliados em genótipos de feijoeiro, A320, Carioca e Ouro Negro, cultivados em potes numa casa de vegetação. Este estudo foi feito durante o dia após a aplicação foliar de $10 \mathrm{~g}$ de $\mathrm{Pi} \mathrm{L}^{-1}$, em plantas hidratadas, e durante um período de deficiência hídrica iniciada dois ou cinco dias após a aplicação. Durante o dia após a aplicação de Pi, não foi observado nenhuma diferença, entre os tratamentos com e sem $\mathrm{Pi}$, nas trocas gasosas de ambas as cultivares. Durante a desidratação, a aplicação de Pi não causou aumento de $g_{s}$, mas causou aumento de $A$, nas medições às 0900, $1200 \mathrm{e}$ 1500 horas, nas cultivares (Carioca e Ouro Negro), mas com um efeito maior na cultivar Ouro Negro, principalmente às 1200 horas. A eficiência intrínseca do uso da água (EIUA) também foi superior nas plantas com suprimento foliar de Pi. Quanto aos componentes da produção, a aplicação de Pi causou aumento do número de vagens das plantas da cultivar Ouro Negro, sob desidratação. Portanto, a aplicação de Pi foliar pode reduzir o efeito de uma desidratação quando aplicado dois dias antes da suspensão da irrigação. Além disso, o potencial fotossintético $\left(A_{c}\right)$ de Ouro Negro com Pi foi superior ao de A320, com e sem Pi, na seca máxima, e ao A320 sem Pi, na reidratação. A dissipação térmica, não fotoquímica (NPQ), do genótipo A320 sem Pi foi maior que com 
Pi e que a do Ouro Negro, com e sem Pi, na reidratação, provavelmente devido aos menores valores de $A$ neste tratamento sem Pi. O uso de fosfato de amônio substituindo a uréia ou o sulfato de amônio, que são aplicados aos $25 \mathrm{DAE}$, é recomendável. 
FOLIAR PHOSPHORUS APPLICATION, PHOTOSYNTHETIC METABOLISM AND YIELD OF COMMON BEAN UNDER WATER DEFICIT

\author{
Author: MAURO GUIDA DOS SANTOS \\ Adviser: Prof. Dr. RICARDO FERRAZ DE OLIVEIRA
}

\title{
SUMMARY
}

The effects of foliar Pi supplying $(\mathrm{Pi})$ on stomatal conductance $\left(g_{s}\right)$ and photosynthesis $(A)$ were measured in genotypes, A320, Carioca and Ouro Negro, grown under greenhouse condition. Measurements of $g_{s}$ and $A$ were taken one day after $\mathrm{Pi}$ application $\left(10 \mathrm{~g} \mathrm{~L}^{-1}\right)$ on well-irrigated plants, and during drought stress period beginning two or five days after Pi supplying. During the day after Pi application, it was not observed any difference on gas exchange of genotypes (Carioca and Ouro Negro) due to the treatments with and without Pi. During water stress, the Pi supplying did not cause increase of $g_{s}$, however, caused increase of $A$ at 0900,1200 and $1500 \mathrm{~h}$ in both genotypes. This effect was higher when considered Ouro Negro at 1200 h. The intrinsic water use efficiency (IWUE) was also increased in Pi-supplied plants. The Pi supplying caused increase on pod number of Ouro Negro plants under water deficit. These results suggest that the foliar Pi application may reduce the effect of water deficit on photosynthesis when supplied two days before the water withholding. In addition, the $\mathrm{O}_{2}$ evolution $\left(A_{c}\right)$ on Ouro negro with extra Pi was higher than for A320, with or without Pi, at the last day of the mild water deficit, and it was higher than A 320 with extra Pi at rehydration. The non-photosynthetic quenching (NPQ), was higher for A320 without Pi at recovery, probably due to the smaller values of $A$ at this treatment. The use of 
ammonium phosphate, instead of urea or ammonium sulphate to be applied as usual 25 DAS, is recommended. 


\section{INTRODUÇÃO}

O feijoeiro comum (Phaseolus vulgaris L.) é uma das mais importantes leguminosas de grão utilizada na alimentação humana em diversos países em desenvolvimento, sendo uma das maiores fontes de proteínas em países da África, América Latina e Ásia (Araújo \& Teixeira, 2003; Fageria et al., 2004). Em função disso, o cultivo do feijoeiro tem grande importância na alimentação do brasileiro, apesar de ainda apresentar baixa produtividade no Brasil (901, 542 e $803 \mathrm{~kg} \mathrm{ha}^{-1}$ na primeira, segunda e terceira safra anual, respectivamente), segundo dados da Companhia Nacional de Abastecimento (2004). Quando cultivado sob sistema de subsistência é pouco tecnificado (Yokoyama et al., 1996) sendo comum, nas regiões tropicais, a utilização de cultivo consorciado como forma de exploração, principalmente em pequenas propriedades (Barreto \& Serpa, 1988). A deficiência hídrica e a nutricional são consideradas as principais causas da baixa produtividade do feijoeiro, uma vez que esta cultura apresenta grande sensibilidade à seca (Boyer, 1976) e deficiência na extração de fósforo (Fageria et al., 2004). A forma de fósforo assimilada pelas plantas é o ortofosfato $\mathrm{H}_{2} \mathrm{PO}_{4}^{-}$ou $\mathrm{HPO}_{4}{ }^{2-}$ (Pi) (Parra et al, 2004), sendo um dos mais importantes macronutrientes para o crescimento e desenvolvimento de plantas.

Os solos brasileiros, por serem acentuadamente intemperizados, apresentam uma capacidade de troca catiônica (CTC) reduzida e uma adsorção aniônica alta. Essa condição proporciona uma redução na saturação de bases, com um aumento gradual na retenção de ânions, como o fosfato, o sulfato e o molibdato, entre outros. Em decorrência disto, os solos mudam gradualmente de fonte para dreno de Pi (Novais \& Smyth, 1999). 
Esta situação, em geral, baixa a produtividade do feijoeiro, em parte devido à reduzida quantidade de Pi no solo disponível para a planta, principalmente em países da África e América do Sul, onde 60\% dos cultivos de feijoeiro são cultivados em solos deficientes em Pi (Yan et al., 1996). Além disso, a deficiência hídrica comum durante o cultivo desta leguminosa, pode reduzir o fluxo de Pi para a parte aérea da planta (Mouat \& Nes, 1986; Silveira \& Moreira, 1990). Esta paralisação do suprimento de Pi do solo para a planta é agravada quando o sistema radicular é pouco denso e a espécie possui baixa eficiência no uso do Pi, como é o caso do feijoeiro (Föse et al., 1988).

Por ser uma planta com alta sensibilidade à falta de água (Boyer, 1978; Bascur et al., 1985; Sharkey \& Seeman, 1989), a deficiência hídrica é considerada o fator ambiental de maior efeito na produção mundial de feijão. Mais de $60 \%$ do seu cultivo em países da África, América Latina, e Ásia apresentam uma redução na produção devido à seca, uma vez que o requerimento hídrico da planta, durante o seu ciclo, não é satisfeito (Singh, 1995).

Os principais mecanismos de adaptação à falta de água do feijoeiro são o controle da abertura estomática (Boyer, 1978; O’Toole et al., 1977; Schulze, 1986) e o sistema radicular mais desenvolvido (Subbarao et al., 1995; Kuruvadi \& Aguilera, 1990). Estes mecanismos são estratégias importantes para evitar a seca, reduzindo a transpiração e maximizando a absorção de água sob estresse hídrico, contribuindo assim para a manutenção do conteúdo hídrico alto da planta (Boyer et al., 1983; Turner, 1986; Subbarao et al., 1995).

A ocorrência do estresse hídrico, por ocasião da pré-floração (período de maior sensibilidade da cultura, quando ocorre a polinização), causa grande redução na produção, conforme já relatado por Magalhães \& Millar (1978), Halterlein, (1983), Kramer \& Boyer (1995) e Pimentel et al. (1999b). Segundo Westgate \& Boyer (1986), uma das causas da maior sensibilidade das culturas de grãos ao déficit hídrico, nesta fase da polinização, é o efeito indireto da desidratação sobre a atividade fotossintética e acumulação de carboidratos de reserva, e menos pelo efeito direto na polinização. Portanto, uma das prováveis causas desta maior sensibilidade da planta na pré-floração seria a redução na atividade fotossintética e exportação de fotoassimilados da folha, que 
é alta neste período (Pimentel, 1999a), e imprescindível para o processo de fecundação nos órgãos reprodutivos (Kramer \& Boyer, 1995).

A exportação de fotoassimilados, por sua vez, é dependente da disponibilidade de Pi no citoplasma, para que ocorra o transporte de trioses do cloroplasto para o citoplasma e a síntese de sacarose (Hendrickson et al., 2004). Durante a fotossíntese, o cloroplasto é um importador de Pi e exportador de triose-P para o citoplasma. Esse fluxo de carbono e Pi é mediado pelo transportador de triose-P, que realiza o antiporte trioseP/Pi através da membrana do cloroplasto (Fliege et al., 1978; Leegood, 1996; Flügge et al., 2003). Desta forma, a falta de Pi citoplasmático limita a síntese de ATP (Lawlor \& Cornic, 2002) e de trioses-P no cloroplasto, o que pode levar à limitação da síntese de Ribulose-1,5- Bisfosfato (RuBP) (Leegood \& Furbank, 1986).

Lauer and Boyer (1992) relataram que, em Phaseolus vulgaris, a limitação da atividade fotossintética em plantas com potencial de água na folha mais negativo é mais bioquímica do que estomática. A taxa fotossintética também é afetada sob potencial de água foliar mais negativo, quando a liberação de $\mathrm{O}_{2}$ foi avaliada em discos foliares de girassol, sem a presença da epiderme, conseqüentemente, sem a limitação estomática (Tang et al., 2002).

Uma das formas para amenizar os efeitos causados pela salinização, em plantas de amendoim, muito semelhantes aos efeitos da seca (Pimentel, 1998), foi a aplicação de um suprimento extra de Pi, via foliar, o qual causou aumento da área foliar, da freqüência estomática e da produção de grãos (Malakondaiah \& Rajeswararao, 1979). Esta prática, também foi utilizada para amenizar os efeitos de baixa temperatura sobre o maquinário fotossintético em videiras, nas quais foi observado um aumento da evolução de $\mathrm{O}_{2}$ que demonstrou uma restrição não-estomática (Hendrickson et al., 2004).

Ao considerar que, em plantas de feijoeiro sob déficit hídrico, a maior limitação da atividade fotossintética não é difusiva (fechamento estomático) e sim metabólica, há a necessidade de se esclarecer que tipo de limitação ocorre sob essa condição. Assim sendo, o propósito deste trabalho foi avaliar se um suprimento extra de Pi foliar, antes de uma deficiência hídrica, poderia reduzir a limitação da atividade fotossintética em plantas de feijoeiro. 


\section{REVISÃO DA LITERATURA}

\subsection{Aspectos gerais sobre a cultura do feijoeiro (Phaseolus vulgaris $L$.)}

O feijoeiro comum (Phaseolus vulgaris L.) é originário do continente americano e cultivado em todo o mundo. O gênero Phaseolus compreende várias espécies, sendo todas diplóides $(2 \mathrm{n}=22)$, dentre as quais quatro são cultivadas: Phaseolus vulgaris L., Phaseolus coccineus L., Phaseolus acutifolius Gray var. latifolius Freem e Phaseolus lunatus var. lunatus (Norman et al., 1995; Zimmermann \& Teixeira, 1996).

O feijoeiro é um dos produtos agrícolas de maior importância econômico-social, em razão de ser cultivado em numerosas áreas e pela mão-de-obra empregada durante o ciclo da cultura, proporcionando a manutenção do homem no campo (Borém \& Carneiro, 1998; Fageria et al., 2004). No Brasil, o cultivo do feijoeiro é viável em três safras anuais, dependendo das condições climáticas da região: no "plantio das águas", de setembro a novembro; no "plantio da seca", de janeiro a março; e no "plantio de outonoinverno" ou "terceira época", de maio a julho. Quando cultivado nesta última época, fazse necessário a utilização de irrigação, porém viável apenas em regiões de inverno ameno (Portes, 1996). O feijoeiro comum geralmente não se adapta bem aos trópicos úmidos, mas se desenvolve bem em áreas com chuvas regulares, desde os trópicos até as zonas temperadas.

O avanço da pesquisa conduzido principalmente por instituições públicas fez com que o Estado de São Paulo ficasse entre os principais produtores do País, tornando a cultura do feijoeiro uma de suas principais explorações agrícolas. De acordo com Vicente et al. (2000), o agronegócio do feijão movimentou entre 137 milhões e 317 milhões de reais, no período de 1994 a 1998 


\subsection{Efeitos do déficit hídrico na cultura do feijoeiro}

O principal estresse abiótico em várias partes do mundo é a seca, sendo um dos principais fatores que contribuem para a acentuada distância entre o potencial produtivo das culturas e a produção comumente alcançada (Subbarao et al., 1995). O feijoeiro (Phaseolus vulgaris L.), ao ser comparado com outras leguminosas de grão como a soja, apresenta uma sensibilidade muito grande à seca, ocasionando uma redução no seu rendimento mesmo em casos de déficit hídrico moderado (-0,7 a -1,0 MPa) (Lopes et al., 1986; Boutraa \& Sanders, 2001).

O controle da perda de água através da transpiração é realizado pelo fechamento estomático, sendo este o único processo de resposta instantânea no contínuo solo-plantaatmosfera (Lawlor \& Cornic, 2002). Todavia, como tal controle está diretamente ligado ao suprimento de $\mathrm{CO}_{2}$ à folha, a condutância estomática deve variar ao longo do tempo, de forma a haver um mínimo de perdas de água para uma máxima assimilação de $\mathrm{CO}_{2}$ (Boyer, 1978; Cornic et al., 1992). Com a imposição da seca, o potencial de água na folha sofre uma progressiva redução, mediante o dessecamento gradual do solo, dependendo do grau de controle estomático da cultivar e/ou da capacidade de absorção de água pelas raízes (Pimentel et al., 1990; Correia \& Pereira, 1995). Desta maneira, o monitoramento deste parâmetro permite avaliar a hidratação das plantas sob déficit hídrico (Passioura, 1997), servindo também como um indicador da eficiência dos mecanismos utilizados pelo vegetal para evitar a desidratação. O monitoramento do potencial de água na folha e da área foliar, durante e após o estresse hídrico, associado à avaliação do rendimento da cultura são bons indicadores de tolerância do feijoeiro à seca (Pimentel \& Perez, 2000). A área foliar é um indicador excelente do efeito da seca, pois o crescimento celular é muito sensível ao déficit hídrico no ar e no solo, causando a paralização do crescimento de folhas, principalmente, o que leva à redução de área foliar (Boyer, 1978).

O comportamento do feijoeiro sob déficit hídrico indica que ocorre uma redução da translocação de carboidratos com conseqüente acúmulo nos sítios de síntese. Há correlação positiva entre o peso específico foliar e a concentração de amido na folha, desta forma, o aumento do peso específico foliar resultaria da redução da translocação 
de carboidratos para os ramos e regiões meristemáticas em plantas submetidas à deficiência hídrica (Guimarães et al., 1996b). Ao considerar que os valores máximos de assimilação fotossintética, transpiração e condutância estomática ocorrem na préfloração, quando há grande demanda de carbono para os órgãos reprodutivos, em plantas de feijoeiro (Pimentel et al., 1999b), a falta de água neste período pode reduzir a fotossíntese líquida e, por conseguinte, decrescendo drasticamente a produtividade.

\subsection{Deficiência hídrica e atividade fotossintética}

Os primeiros efeitos da desidratação são observados na redução do crescimento foliar e da condutância estomática (Boyer, 1978). Com a severidade do estresse, a fotossíntese, além de ser reduzida pelo fechamento estomático, será afetada pela atividade dos fotossistemas e do ciclo de Calvin (Chaves, 1991). A fotossíntese líquida e a transpiração do feijoeiro começam a serem reduzidas quando o potencial de água na folha se situa entre -0,3 e -0,5 MPa. Com o decréscimo do potencial de água na folha para $-0,9$ a $-1,0 \mathrm{MPa}$, a fotossíntese líquida e a transpiração são praticamente nulas $\left(\mathrm{O}^{\prime}\right.$ Toole et al., 1977).

Estudos em feijoeiro demonstram que o déficit hídrico causa reduções simultâneas na abertura estomática e na capacidade bioquímica para a realização da fotossíntese, sendo que a atividade bioquímica pode limitar mais a fotossíntese, que o fechamento estomático (Lauer \& Boyer, 1992). Estes autores mediram a pressão parcial interna de $\mathrm{CO}_{2}$ em feijoeiro comum, sob baixo potencial de água na folha, e observaram que esta pressão teve seu valor aumentado, o que indica que o fechamento estomático não foi o principal fator limitante da assimilação fotossintética de $\mathrm{CO}_{2}$, devido à alta disponibilidade desse substrato dentro da folha. Novas evidências indicando a limitação bioquímica da fotossíntese foram apresentadas por Tang et al. (2002). Conforme estes autores, plantas de girassol sob baixo potencial de água na folha, e cuja epiderme foi retirada, continuaram a apresentar valores menores de evolução de $\mathrm{O}_{2}$, quando comparada com a testemunha, o que evidencia uma limitação não-estomática da atividade fotossintética. 
O início do estádio reprodutivo, compreendendo a pré-floração e a floração, é considerado um dos mais sensíveis ao suprimento inadequado de água (Magalhães \& Millar, 1979; Halterlein, 1983). Uma possível causa da maior sensibilidade ao déficit hídrico nesta fase seria indireta devido ao efeito da desidratação sobre a atividade fotossintética, sendo o efeito direto na polinização, de menor importância (Westgate \& Boyer, 1986). Segundo Wardlaw (1990), o requerimento de fotossintatos se mostra relativamente pequeno para a floração, porém, um nível crítico de carboidratos nas folhas é requerido para estimular a fertilização e o desenvolvimento do embrião; e esta reserva de fotossintatos será utilizada na formação das vagens e dos grãos, quando a atividade fotossintética é baixa (Pimentel et al., 1999 a, b). A baixa disponibilidade de fotossintatos na planta mãe, em conseqüência da inibição da fotossíntese, proporcionaria a paralisação irreversível do desenvolvimento do embrião (Kramer \& Boyer, 1995). Além disto, o feijoeiro apresenta um período curto de floração, com um vingamento de vagens praticamente nulo a partir do décimo dia de floração, sendo essa uma outra causa para a redução da produção de grãos, quando o déficit hídrico ocorre na floração (Magalhães \& Millar, 1979).

\subsection{Principais mecanismos de tolerância à seca no feijoeiro}

O feijoeiro apresenta duas estratégias principais para se evitar a seca: o controle estomático (O' Toole et al., 1977; Schulze, 1986) e o desenvolvimento do sistema radicular (Kuruvadi \& Aguilera, 1990), sendo este último observado em poucos genótipos. Estes mecanismos se caracterizam como estratégias para evitar o estresse, reduzindo a perda de água por transpiração e maximizando a absorção de água sob déficit hídrico, contribuindo desse modo para a manutenção de um alto conteúdo de água da planta (Turner, 1986; Subbarao et al., 1995). Quanto ao controle estomático,

certos genótipos como o A222, A285 e A320 apresentam um rápido fechamento estomático, sob desidratação, mantendo o seu potencial de água na folha mais alto (Pimentel et al., 1990; Pimentel \& Pérez, 2000). Por outro lado, o aumento da densidade das raízes é considerado o mais importante mecanismo para incrementar a absorção de água (Turner, 1986), mas como dito anteriormente, poucos genótipos de feijoeiro 
apresentam esta característica. Como o feijoeiro comum apresenta um sistema radicular pouco desenvolvido, ele torna-se sensível às épocas de precipitação irregular (Guimarães, 1996a).

Outro mecanismo de tolerância à seca utilizado pelas plantas de feijoeiro é a flexibilidade na orientação foliar em relação aos raios solares, isto é, as folhas posicionam-se de forma perpendicular aos raios solares pela manhã e de forma paralela ao meio dia, aumentando, assim, a interceptação da luz pelo amanhecer e no final da tarde, bem como reduzindo o tempo de exposição ao meio dia (Berg \& Hsiao, 1986). As diferentes cultivares de feijoeiro comum podem apresentar diferentes temperaturas foliares sob mesmas condições de campo ou casa de vegetação, em virtude dos diferentes tamanhos de folha, orientações, e taxa de transpiração por unidade de área foliar (Comstock \& Ehleringer, 1993).

\subsection{Disponibilidade no solo e eficiência do feijoeiro na absorção de fósforo}

O baixo teor de fósforo (Pi) disponível no solo é a limitação nutricional mais generalizada para produção agrícola nos trópicos e sub-trópicos (Raghothama, 1999; Fageria et al., 2004; Fernandez \& Ascencio, 1994; Parra et al., 2004). Das áreas produtoras de feijão na América Latina, 50\% estão com baixa concentração de $\mathrm{Pi}$, situação esta, semelhante às áreas produtoras da África (CIAT, 1987; Yan et al., 1996). Essa situação é agravada com o intemperismo, uma vez que os solos passam gradualmente de fonte para dreno de Pi. Em condições extremas de intemperismo, como é o caso de alguns Latossolos de cerrado, o solo é um forte dreno de Pi (Novais \& Smyth, 1999) e mais de 80\% do Pi existente no solo apresenta-se adsorvido, precipitado ou convertido à forma orgânica (Schachtman et al., 1998).

Genótipos de feijoeiro diferem quanto à eficiência no uso do Pi para o crescimento e a produção (Yan et al., 1995). Esta variação de eficiência no uso de Pi por diferentes genótipos (comum, cultivados e selvagens) pode ser um critério útil de seleção para cultivos em que o suprimento de Pi é inadequado (Araújo et al., 1998). Entretanto, pouco se conhece sobre os fatores que afetam a taxa de absorção e a 
remobilização de Pi citoplasmático e vacuolar na folha, sob suprimento inadequado de fósforo (Thorne, 1958; Lauer et al., 1989; Lee \& Ratcliffe, 1993).

Thorne (1958), trabalhando com aplicação foliar de fósforo marcado $\left({ }^{32} \mathrm{P}\right)$, observou que a taxa de absorção por folhas de feijoeiro (Phaseolus vulgaris L.) é rápida durante as primeiras horas, e tornando-se nula após quatro dias. $\mathrm{O}^{32} \mathrm{P}$ foi detectado nas raízes após três horas, e continuou a ser translocado da folha tratada até seis dias após a aplicação. As concentrações de Pi citoplasmática são constantemente mantidas em torno de 5 a $10 \mathrm{mM}$, com alguma independência da concentração externa de Pi. Todavia, a concentração de Pi vacuolar é muito variável, sobretudo sob condições limitantes (Lee \& Ratcliffe, 1993; Grossman \& Takahashi, 2001).

Períodos de veranico, com duração aproximada de dez dias fazem com que o fluxo difusivo de Pi do solo para a planta seja praticamente interrompido, podendo causar perdas significativas de produtividade (Mouat \& Nes, 1986; Novais \& Smyth, 1999). A freqüente ameaça de ocorrência de um veranico, faz com que haja a necessidade de um estoque de Pi em condições ótimas de disponibilidade de água, visto que a absorção de Pi é dependente da disponibilidade de água no solo. Contudo, após a reidratação, a absorção e assimilação de Pi deverá ser rápida, iniciando assim que o fluxo difusivo for restabelecido (Novais \& Smyth, 1999). Segundo Novais \& Smyth, (1999), anteriormente à perda de turgidez e folhas enroladas, sintomas comumente observados em decorrência da falta de água no campo, há perda de produtividade por falta de um estoque de Pi interno capaz de manter o crescimento da planta, por longos períodos, sem sua reposição do solo. O estudo sobre o efeito de diferentes doses de Pi e de diferentes lâminas de irrigação, aplicados na cultura do feijoeiro por dois anos consecutivos, sob condições de campo, mostrou que sob baixa lâmina de água a resposta à aplicação de Pi foi pequena (Silveira \& Moreira, 1990).

\subsection{Regulação da fotossíntese pela disponibilidade de Pi citoplasmático}

A influência do ortofosfato inorgânico (Pi) sobre a fotossíntese foi discutida por diversos autores (Rychter \& Mikulska, 1990; Flügge et al., 2003; Hendrickson et al., 2004), sendo considerada um fator importante na regulação da fotossíntese (Sawada, 
1990; Anwaruzzaman et al., 1995; Leegood, 1996). Grande parte da fotossíntese no cloroplasto seria mais fielmente representada pela equação: $3 \mathrm{CO}_{2}+6 \mathrm{H}_{2} \mathrm{O}+\mathrm{Pi} \rightarrow$ triose$\mathrm{P}+3 \mathrm{H}_{2} \mathrm{O}+3 \mathrm{O}_{2}$. Esta equação ainda sumariza o principal movimento de metabólitos para dentro e fora do cloroplasto, via o transportador de triose-P/Pi, o que a torna adequada para representar o processo fotossintético. $\mathrm{O}$ transportador de triose-P/Pi pode exercer uma limitação durante a biossíntese de sacarose in vivo (Gerhardt et al., 1987; Leegood, 1996) uma vez que o Pi requerido pelo cloroplasto é suprido pelo Pi liberado no citoplasma, durante a síntese de sacarose, a partir da triose-P exportada do cloroplasto (Sivak \& Walker, 1985).

Durante o estádio de polinização é necessário uma alta fixação de $\mathrm{CO}_{2}$ (Pimentel, 1998), com alta acumulação de fotoassimilados nas folhas do feijoeiro (Wardlaw, 1990; Pimentel, 1998). Deste modo, neste estádio a produção de triose-P aumentará,levando ao acúmulo de sacarose nas folhas, para serem transportados para os órgãos reprodutivos, nos estádios seguintes de formação e enchimento dos frutos (Kramer \& Boyer, 1995). Os fotossintatos também podem ser armazenados durante o dia, sob a forma de amido, dentro dos cloroplastos formando o "pool" diurno armazenado, que é mobilizado durante a noite seguinte e exportado para os tecidos dos drenos para a respiração de manutenção (Flügge, 1995). Leegood (1996) relata que com o aumento na concentração dos intermediários fosforilados fotossintéticos, pode ocorrer redução na disponibilidade do Pi citoplasmático a ser remobilizado para os cloroplastos pelo transportador de trioseP/Pi. Em decorrência disto, pode haver a redução da produção de fotoassimilados no cloroplasto, devido à diminuição da síntese de RuBP. A redução na disponibilidade de Pi, no estroma, limita a taxa de síntese de ATP (Sivak \& Walker, 1986; Tezara et al., 1999) e controla o pH nos cloroplastos (Hall \& Rao, 1994).

A partição de assimilados entre amido e sacarose é dependente da interação de três fatores: a concentração de Pi citoplasmático, que regula a exportação de triose-P do cloroplasto; a atividade das principais enzimas da via de síntese de sacarose (frutose bifosfato fosfatase, sacarose fosfato sintase, e possivelmente a sacarose fosfato fosfatase); e a regulação da atividade da ADP-glicose pirofosforilase. Pouco se conhece sobre o transporte de Pi através do tonoplasto, todavia estudos prévios revelam que há 
um sistema de transporte de Pi no tonoplasto, regulado pelo gradiente eletroquímico, através da bomba de prótons (ATPase- $\left.\mathrm{H}^{+}\right)$(Massonneau et al., 2000).

Uma outra possibilidade da limitação fotossintética pelo Pi seria pelo seu efeito na ativação da Rubisco, já que o mecanismo de ativação total desta enzima é importante para compreensão do metabolismo de carbono "in vivo" nas plantas (Anwaruzzaman et al., 1995). A cinética de sua ativação sugere dois possíveis mecanismos pelo $\mathrm{Pi}$, isto é, o Pi substituiria o $\mathrm{CO}_{2}$ na função de agente indutor e, em uma segunda hipótese, o Pi permitiria a ligação do $\mathrm{CO}_{2}$ ao sítio de ativação (Anwaruzzaman et al., 1995).

Deste modo, este estudo avaliou o efeito da aplicação foliar de Pi sobre o metabolismo fotossintético, antes da ocorrência de um déficit hídrico, a partir da hipótese que os efeitos negativos da seca sobre a fotossíntese podem ser amenizados com uma maior disponibilidade de Pi foliar. 


\section{APLICAÇÃO FOLIAR DE FÓSFORO E RESPOSTA DO METABOLISMO FOTOSSINTÉTICO AO DÉFICIT HÍDRICO EM Phaseolus vulgaris}

\subsection{Resumo}

Os efeitos da aplicação foliar de fósforo (Pi) na condutância estomática $\left(g_{s}\right)$ e na fotossíntese $(A)$, foram avaliados em dois genótipos de feijoeiro, Carioca e Ouro Negro, cultivados em potes numa casa de vegetação. Este estudo foi feito durante o dia após a aplicação foliar de $10 \mathrm{~g}$ de $\mathrm{Pi} \mathrm{L}^{-1}$, em plantas hidratadas, e durante um período de deficiência hídrica iniciada dois dias após a aplicação. Durante o dia após a aplicação de $\mathrm{Pi}$, não foi observado nenhuma diferença, entre os tratamentos com e sem $\mathrm{Pi}$, nas trocas gasosas de ambas as cultivares. Durante a desidratação, a aplicação de Pi não causou aumento de $g_{s}$, mas causou aumento de $A$, nas medições às 0900, 1200 e 1500 horas, em ambas as cultivares, mas com um efeito maior na cultivar Ouro Negro, principalmente às 1200 horas. A eficiência intrínseca do uso da água (EIUA) também foi superior nas plantas com suprimento foliar de Pi. Quanto aos componentes da produção, a aplicação de Pi causou aumento do número de vagens das plantas da cultivar Ouro Negro, sob desidratação. Portanto, a aplicação de Pi foliar pode reduzir o efeito de uma desidratação quando aplicado dois dias antes da suspensão da irrigação.

Termos de indexação: feijoeiro comum; fotossíntese, seca, trocas gasosas.

\subsection{Summary}

FOLIAR PHOSPHORUS APPLICATION AND PHOTOSYNTHETIC METABOLISM RESPONSE TO WATER DEFICIT IN Phaseolus vulgaris 
The effects of foliar $\mathrm{Pi}$ supplying (Pi) on stomatal conductance $\left(g_{s}\right)$ and photosynthesis $(A)$ were measured in two bean genotypes, Carioca and Ouro Negro, grown under greenhouse condition. Measurements of $g_{s}$ and $A$ were taken one day after Pi application $\left(10 \mathrm{~g} \mathrm{~L}^{-1}\right)$ on well-irrigated plants, and during drought stress period beginning two days after Pi supplying. During the day after Pi application, it was not observed any difference on gas exchange of both genotypes due to the treatments with and without Pi. During water stress, the Pi supplying did not cause increase of $g_{s}$, however, caused increase of $A$ at 0900,1200 and $1500 \mathrm{~h}$ in both genotypes. This effect was higher when considered Ouro Negro at $1200 \mathrm{~h}$. The intrinsic water use efficiency (IWUE) was also increased in Pi-supplied plants. The Pi supplying caused increase on pod number of Ouro Negro plants under water deficit. These results suggest that the foliar Pi application may reduce the effect of water deficit on photosynthesis when supplied two days before the water withholding.

Index terms: common bean, drought, gas exchange, photosynthesis.

\subsection{Introdução}

A deficiência de água e de fósforo (Pi) são alguns dos mais importantes fatores limitantes ao crescimento de plantas em regiões tropicais (Fageria et al., 1997). Isto porque mais de $60 \%$ do feijoeiro comum cultivado em países em desenvolvimento da América Latina, África e Ásia sofre os efeitos da seca em algum estádio do desenvolvimento (Singh, 1995). Além disto, a deficiência de Pi é uma grande limitação para a fotossíntese e a sua baixa disponibilidade afeta a produção de culturas em $96 \%$ dos solos ácidos e pouco férteis na América tropical (Fageria et al., 2004), especialmente para as leguminosas, tal como o feijoeiro comum. O feijoeiro tem baixa capacidade de troca de cátions e pequeno volume radicular e, assim, é um pobre extrator de água e Pi do solo, quando comparado com a maioria das gramíneas, por exemplo (Föse et al., 1988; Fageria et al., 2004). Assim, um menor conteúdo de Pi nos tecidos das leguminosas cultivadas, nessas regiões tropicais, pode agravar as injúrias causadas pelo déficit hídrico à fotossíntese, especialmente no estádio de polinização, isto é, o estádio de pré-floração para feijões. Neste estádio, a taxa líquida de assimilação de $\mathrm{CO}_{2}(A)$ é 
maior (Pimentel et al., 1999b), causando um aumento no conteúdo foliar de carboidratos, que são reservas para sustentar o crescimento do embrião, após a polinização (Westgate and Boyer, 1986). De acordo com esses estudos, a pré-floração é o estádio de maior sensibilidade do feijoeiro (Pimentel et al., 1999a).

Quando as plantas são submetidas à um déficit hídrico, os estômatos se fecham para reduzir a perda de água das folhas para a atmosfera, limitando a difusão de $\mathrm{CO}_{2}$ da atmosfera para as células do mesofilo. Alguns autores têm considerado o fechamento estomático, mais que a atividade metabólica, como a principal causa da redução de $A$ sob seca, e que as limitações metabólicas ocorrem somente sob déficit hídrico severo (Chaves et al., 2002; Lawlor \& Cornic, 2002). Contudo, Lauer and Boyer (1992) demonstraram aumento da concentração interna de $\mathrm{CO}_{2}$ em folhas de feijoeiro sob déficit hídrico, entre outras espécies, indicando que a condutância estomática $\left(g_{s}\right)$ não inibiu $A$, a qual tornou-se nula, mesmo sob alta disponibilidade de $\mathrm{CO}_{2}$. Provavelmente, o fechamento estomático contribuiu para a limitação de $A$, nas fases iniciais da desidratação foliar, embora danos metabólicos diretos e significativos possam ser considerados como a principal causa da inibição da fotossíntese sob baixo potencial da água da folha ( $\left.\Psi_{l}\right)$ ainda relativamente alto, como discutido por Tang et al. (2002). As causas desta redução no metabolismo fotossintético, sob seca, ainda não estão claras. Por exemplo, a atividade e o conteúdo da rubisco foram afetados em alguns estudos, mas não em outros (Flexas \& Medrano, 2002). Assim, é comum aceitar que existe uma redução na habilidade do cloroplasto para regenerar a RuBP, devido ao suprimento reduzido de ATP, o qual pode ser atribuído à menor síntese de ATP (Tezara et al., 1999). Flexas e Medrano (2002) analisaram a literatura e, em muitos estudos, houve uma redução no conteúdo de RuBP e ATP em folhas, mesmo sob uma deficiência hídrica moderada. Entretanto, há importantes exceções nas quais o conteúdo de RuBP do feijoeiro sob seca moderada não foi afetado (Sharkey and Seeman, 1989), e a síntese de ATP não foi inibida mesmo sob déficit hídrico severo (Ortiz-López et al., 1991).

A redução da exportação de triose-P a partir do cloroplasto, que diminui a síntese de ATP no cloroplasto, pode ser causada pela baixa disponibilidade de Pi citoplasmático livre para ser trocado por triose-P do cloroplasto, através do translocador de fosfato 
(TF), em um antiporte Triose-P/Pi (Flügge et al., 2003). A falta d'água afetaria esses processos devido à acumulação de intermediários fosforilados fotossintéticos tanto no citoplasma como no vacúolo, com uma redução da atividade da sacarose fosfato sintase (SFS) (Vassey et al., 1991) e consequentemente reduzindo o conteúdo de Pi citoplasmático. Sob seca, há uma acumulação da frutose-2,6-bifosfato (Yordanov et al., 2000), a qual controla o sistema de antiporte no TF e, consequentemente, a fotofosforilação e o ciclo de Calvin, regulando a importação de Pi e a exportação de carbono, no cloroplasto (Flügge et al., 2003). Assim, a alta sensibilidade da liberação de $\mathrm{O}_{2}$ do feijoeiro ao déficit hídrico, no estádio de polinização (Pimentel et al., 1999a), pode ser parcialmente explicada por um baixo conteúdo citoplasmático de $\mathrm{Pi}$, reduzindo a síntese de ATP e RuBP no cloroplasto.

O objetivo do presente trabalho foi verificar se o suprimento extra de Pi via foliar, antes da imposição de deficiência hídrica, pode amenizar a resposta do metabolismo fotossintético à seca em feijoeiro comum, no estádio de polinização (préfloração), sobretudo porque esta é uma espécie sensível à seca e pobre extratora de Pi do solo.

\subsection{Material e métodos}

\subsubsection{Material vegetal e condições de crescimento}

Plantas de feijoeiro comum (Phaseolus vulgaris L.), genótipos Carioca e Ouro Negro, foram cultivadas sob condições de casa de vegetação em potes de $10 \mathrm{~L}$. O Carioca é o genótipo mais comumente cultivado no Brasil e o Ouro Negro é um novo genótipo de sementes pretas.

O delineamento experimental foi em blocos ao acaso (fatorial triplo) com os seguintes fatores: 2 genótipos X 2 níveis de Pi X 2 regimes hídricos X 3 repetições, totalizando 24 potes. As plantas foram hidratadas regularmente até a imposição do déficit hídrico por supensão da irrigação, quando ambos os genótipos estavam no estádio de pré-floração. O meio de crescimento consistiu de uma mistura de substrato com vermiculita expandida na proporção de 4:1 (Plantimax, Eucatex Inc., Brasil). As plantas 
foram adubadas com solução nutritiva completa descrita por McCree (1986). Durante o ciclo das plantas, a temperatura do ar dentro da casa de vegetação variou de 18 a $37^{\circ} \mathrm{C}$.

\subsubsection{Suplementação de fósforo e déficit hídrico}

O suprimento extra de $\mathrm{Pi}$, foi realizado em metade das plantas via pulverização com 12,5 $\mathrm{mL}$ de $10 \mathrm{~g} \mathrm{Pi} \mathrm{L}{ }^{-1}$, na forma de fosfato monoamonio $\left(\left(\mathrm{NH}_{4}\right) \mathrm{H}_{2} \mathrm{PO}_{4}\right)$, sendo que a outra metade foi pulverizada com 2,64 $\mathrm{g} \mathrm{N} \mathrm{L}^{-1}$, na forma de uréia $\left(\left(\mathrm{NH}_{2}\right)_{2} \mathrm{CO}\right)$, para compensar o $\mathrm{N}$ adicionado no tratamento com Pi (Teixeira \& Araújo, 1999). As plantas foram pulverizadas dois dias antes da imposição da deficiência hídrica. Quando o potencial chegou a $-1,0 \mathrm{MPa}$ após três dias de dessecamento, as plantas foram reidratadas, caracterizando assim um déficit hídrico moderado para o feijoeiro (Sharkey \& Seemann, 1989).

\subsubsection{Avaliação do status hídrico das plantas}

A tensão no xilema foi medida diariamente no final do período escuro (antes do amanhecer) com uma câmara de pressão de Scholander (Soilmoisture Equipment Corp., Santa Bárbara, CA, USA), na quarta folha totalmente expandida e não senescente, contada a partir da base da planta. Essas medidas foram assumidas como se fossem equivalentes ao potencial da água da folha.

\subsubsection{Medidas de trocas gasosas}

A taxa de assimilação de $\mathrm{CO}_{2}(A)$ e a condutância estomática $\left(g_{s}\right)$ foram medidas, usando um analisador de gases por infravermelho (LI-6400, LICOR, Inc., Lincoln, USA), na terceira folha totalmente expandida, contada a partir do ápice da planta. A densidade de fluxo de fótons fotossintéticos (DFFF) foi controlada de acordo com a intensidade luminosa do ambiente no momento da medida das trocas gasosas, usando uma fonte de luz com o componente azul. O déficit de pressão de vapor variou entre 0,5 e $2,0 \mathrm{kPa}$. $\mathrm{O}$ ar coletado do lado de fora da casa de vegetação foi passado por um galão fechado e então bombeado para dentro do medidor de fotossíntese, com uma concentração de $\mathrm{CO}_{2}$ em torno de $360 \mu \mathrm{mol} \mathrm{mol}^{-1}$. Essas medidas foram feitas em 
plantas bem hidratadas, de duas em duas horas, durante todo o período de luz no dia seguinte da pulverização com Pi foliar. Além disso, foram medidas as trocas gasosas, às 09:00, 12:00 e 15:00 h, durante os três dias de deficiência hídrica, iniciada dois dias após a pulverização, assim como dois dias depois da reidratação dos potes. A eficiência intrínseca do uso da água (EIUA) foi estimada a partir da relação $A / g_{s}$ de acordo com Osmond et al. (1980).

\subsubsection{Componentes da produção}

No final do ciclo das plantas, os efeitos de ambos os tratamentos, déficit hídrico e extra Pi foliar foram avaliados nos componentes de produção: peso de sementes por planta e número de vagens e sementes por planta.

\subsubsection{Análise estatística}

Os dados foram submetidos, a analise de variância (ANOVA), e as médias foram comparadas e segregadas pelo teste Tukey, quando detectada significância estatística.

\subsection{Resultados}

\subsubsection{Relações hídricas e trocas gasosas sob suplementação extra de fósforo e déficit hídrico}

Um dia depois da pulverização foliar com Pi não foi observada nenhuma mudança $(\mathrm{p}>0,05)$ no comportamento diurno de $A$ e $g_{s}$ dos genótipos hidratados (Figura 1). $A$ e $g_{s}$ foram maiores na primeira metade do dia, tendo seus valores reduzidos gradualmente durante o resto do dia. 
Com a falta de água, iniciada dois dias após a pulverização com $\mathrm{Pi}$, o potencial da água da folha não diferiu entre os dois genótipos, assim como entre os tratamentos com e sem Pi foliar durante a imposição da deficiência hídrica e na recuperação (Figura 2). A imposição de um déficit hídrico moderado dois dias depois da pulverização com Pi foliar causou redução significativa de $g_{s}$ em ambos os genótipos já a partir do primeiro dia, não apresentando recuperação completa mesmo após a reidratação (Figura 3).

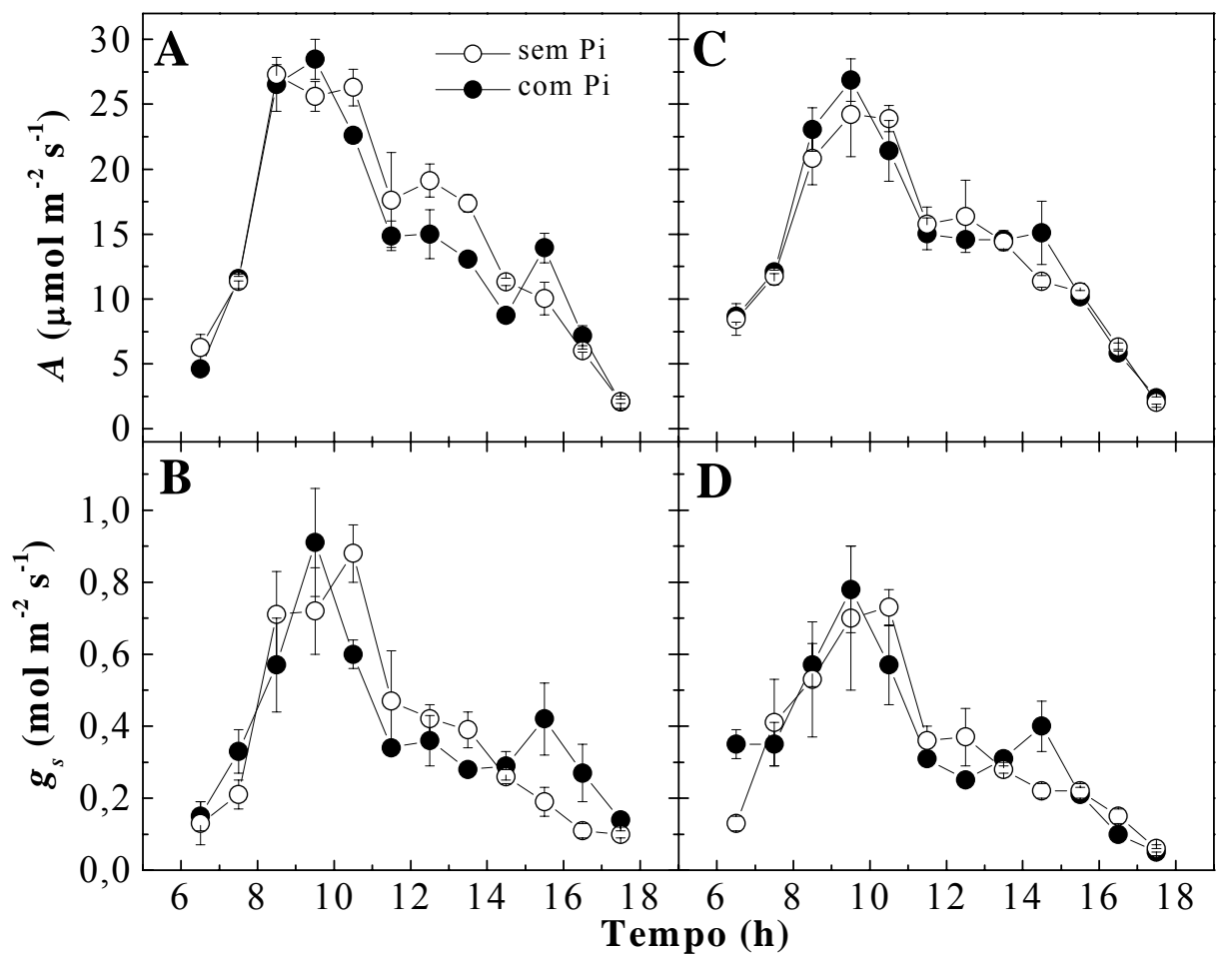

Figura 1 - Curso diário da assimilação de $\mathrm{CO}_{2}(A)$ e condutância estomática $\left(g_{s}\right)$ em plantas, com suprimento de Pi foliar (círculo fechado) e sem Pi (círculo aberto), dos genótipos de feijoeiro Carioca (A, B) e Ouro Negro (C, D) um dia após o suprimento de Pi foliar. Os dados são valores médios \pm erro padrão $(n=3)$ 


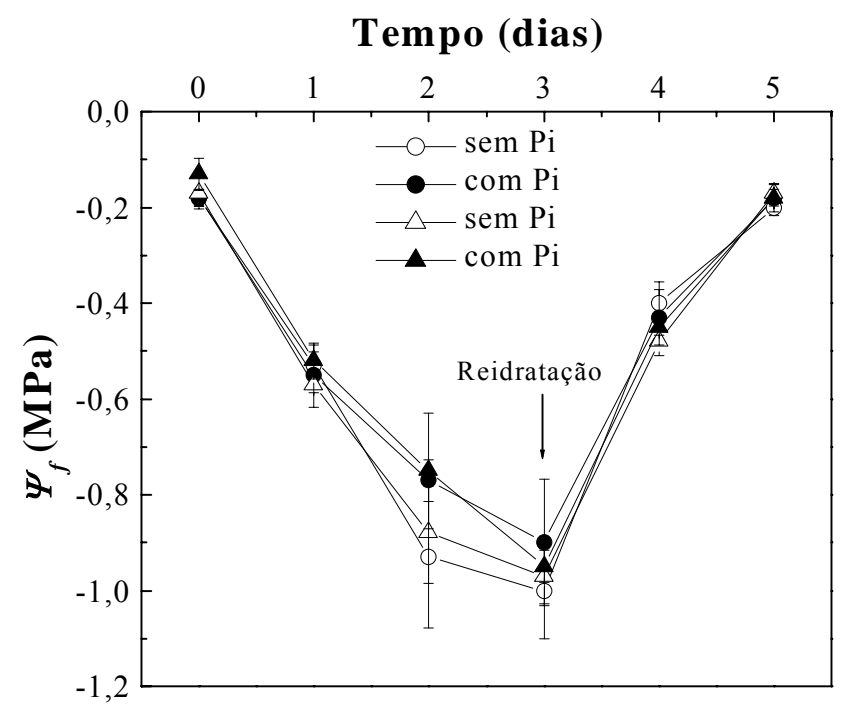

Figura 2 - Potencial da água na folha ( $\left.\Psi_{f}\right)$ em plantas, com suprimento de Pi foliar (símbolos fechados) e sem Pi (símbolos abertos), dos genótipos de feijoeiro Carioca (círculos) e Ouro Negro (triângulos), submetidos a três dias de déficit hídrico e dois dias de reidratação. A irrigação foi suspensa após dois dias da aplicação de Pi foliar. As medidas foram realizadas antes do amanhecer. Os dados são valores médios \pm erro padrão $(n=3)$ 


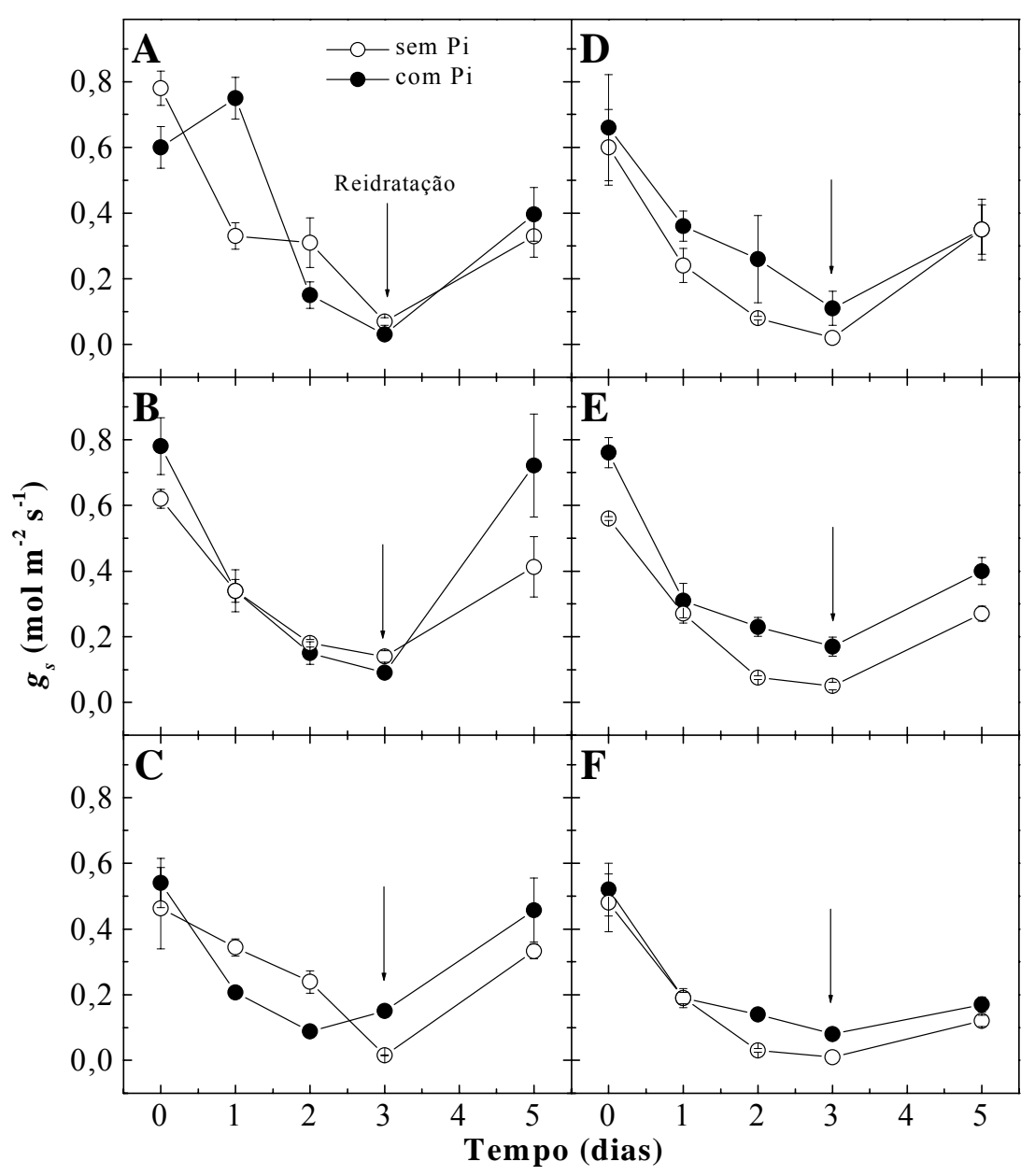

Figura 3 - Condutância estomática $\left(g_{s}\right)$ em plantas, com suprimento de Pi foliar (círculo fechado) e sem Pi (círculo aberto), dos genótipos de feijoeiro comum, Carioca $(\mathrm{A}, \mathrm{B}, \mathrm{C})$ e Ouro Negro (D, E, F), submetidos a três dias de déficit hídrico e dois dias de reidratação. A irrigação foi suspensa após dois dias da aplicação de Pi foliar. As medidas foram realizadas às 09:00 (A, D), 12:00 (B, E), e 15:00 h (C, F). A temperatura média diária variou de 28,0 a $28,9{ }^{\circ} \mathrm{C}$. Os dados são valores médios \pm erro padrão $(n=3)$ 
As plantas, com suprimento de Pi sob seca, do genótipo Carioca exibiram maiores valores de $g_{s}$ às 09:00 h no primeiro dia de déficit hídrico e às 12:00 h após a reidratação, mas não houve diferença significativa no comportamento da $g_{s}$ do Ouro Negro em qualquer hora do dia. A pulverização com Pi foliar causou respostas distintas entre os genótipos, quando considerado $A$ sob déficit hídrico (Figura 4). Com o suprimento foliar de $\mathrm{Pi}$, o Carioca exibiu maiores valores de $A$, quando comparado às plantas sem Pi foliar, somente no primeiro dia de déficit hídrico às 09:00 h, e no terceiro dia, às 15:00 h (Figuras 4A e C). No entanto, para o Ouro Negro, o suprimento extra de Pi induziu maiores valores de $A$ em todas as avaliações durante o dia (Figura 4D a F). Às 09:00 h, as plantas de Ouro Negro, sob seca e supridas com Pi foliar, apresentaram maiores valores de $A$ no segundo e terceiro dias de estresse; às 12:00 h, essas plantas tiveram maiores valores de $A$ nos dias zero, dois e três de deficiência hídrica, e na reidratação; e às 1500 h, as plantas de Ouro Negro com Pi foliar tiveram maiores valores $(\mathrm{p}<0,01)$ de $A$ no primeiro, segundo e terceiro dia de déficit hídrico (Figura 4D a F). A maior $A$ das plantas sob seca e supridas com Pi foliar quando comparadas com as plantas testemunhas (sob seca), proporcionou maior eficiência intrínseca do uso da água, ou seja, para um mesmo valor de $g_{s}$ o de $A$ foi maior (Figura 5).

\subsubsection{Os efeitos da suplementação extra de fósforo e do déficit hídrico moderado nos componentes de produção}

A seca moderada causou redução no número de sementes por planta do Carioca sem Pi foliar. Contudo, o suprimento extra de Pi foliar aumentou o número de vagens por planta do Ouro Negro, não afetando os demais componentes (Tabela 1). 


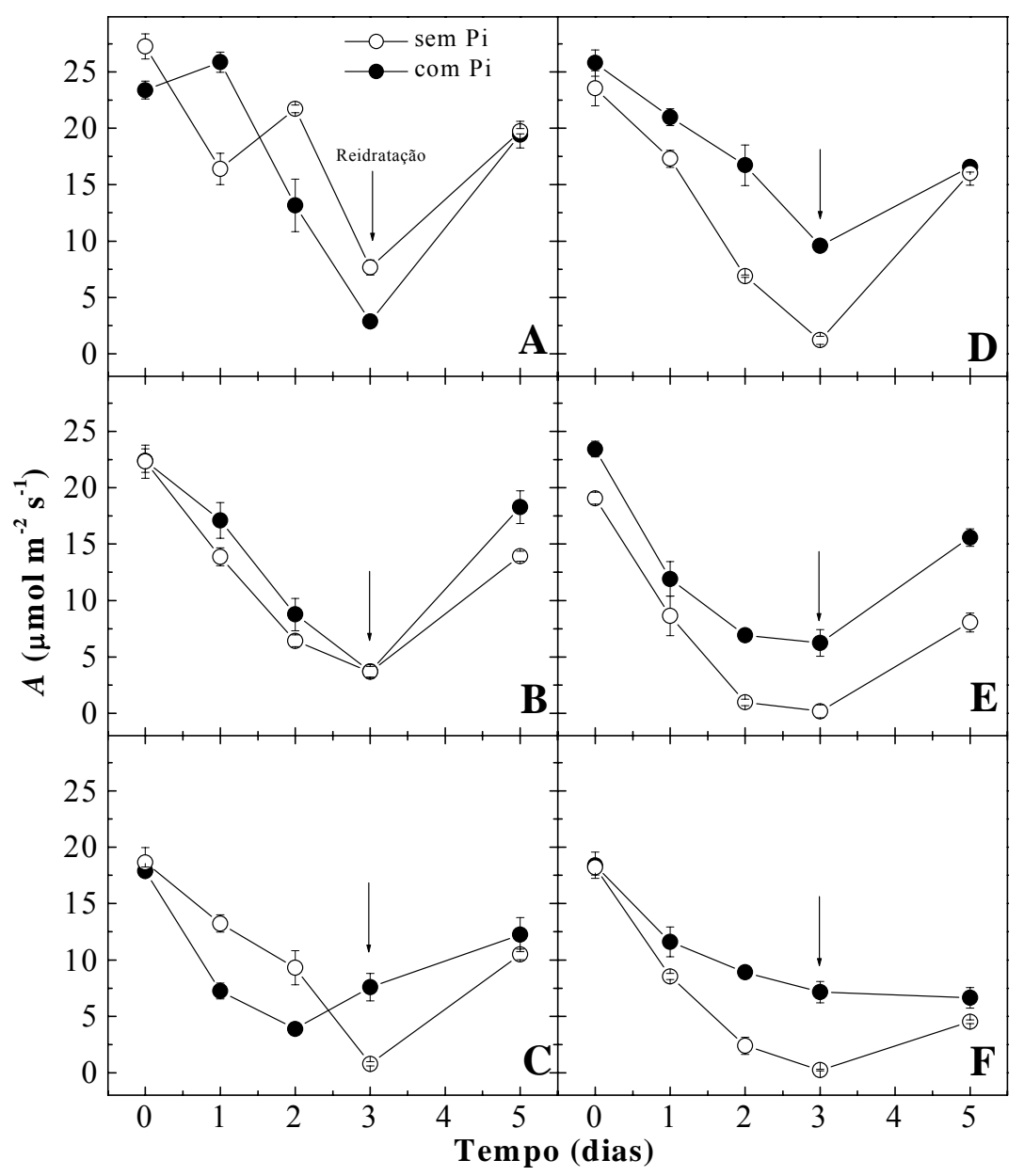

Figura 4 - Assimilação de $\mathrm{CO}_{2}(A)$ em plantas, com suprimento de Pi foliar (círculo fechado) e sem Pi (círculo aberto), dos genótipos de feijoeiro comum, Carioca (A, B, C) e Ouro Negro (D, E, F), submetidos a três dias de déficit hídrico e dois dias de reidratação. A irrigação foi suspensa após dois dias da aplicação de Pi foliar. As medidas foram realizadas às 09:00 (A, D), 12:00 $(\mathrm{B}, \mathrm{E})$, e 15:00 h $(\mathrm{C}, \mathrm{F})$. A temperatura média diária variou de 28,0 a $28,9{ }^{\circ} \mathrm{C}$. Os dados são valores médios \pm erro padrão $(n=3)$ 


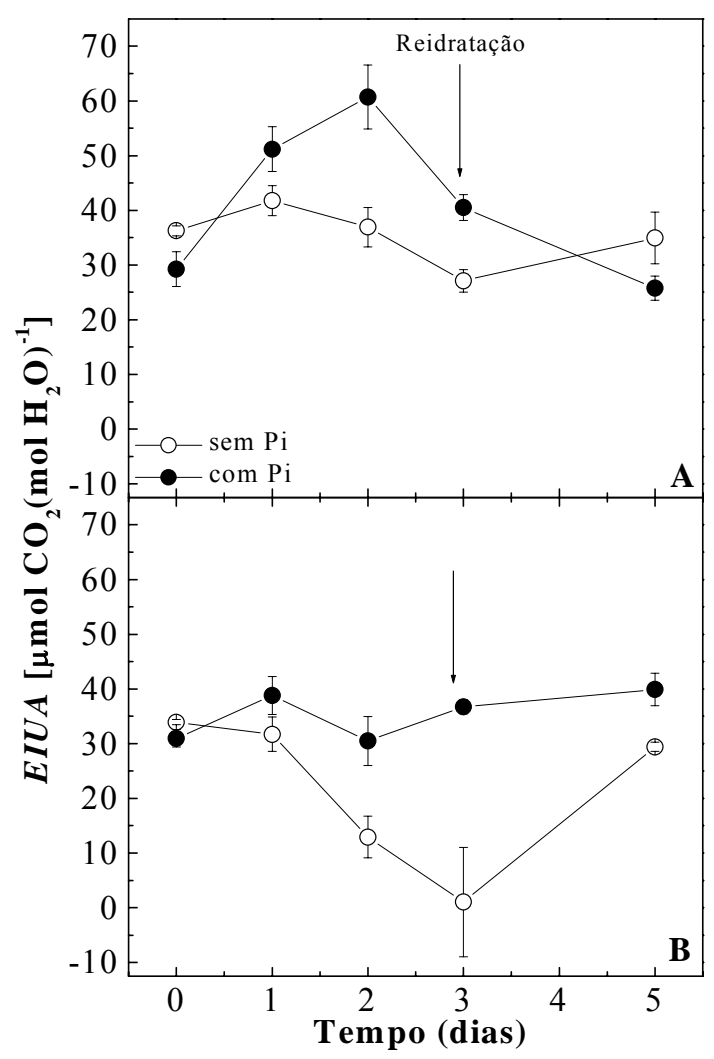

Figura 5 - Eficiência intrínseca do uso da água (EIUA) ao meio dia (12:00 h) em plantas, com suprimento de Pi foliar (círculo fechado) e sem Pi (círculo aberto), dos genótipos de feijoeiro comum, Carioca (A) e Ouro Negro (B), submetidos a três dias de déficit hídrico e dois dias de reidratação. A irrigação foi suspensa após dois dias da aplicação de Pi foliar. Os dados são valores médios da relação $A / g s \pm$ erro padrão $(n=3)$ 
Tabela 1. Componentes de produção dos genótipos de feijoeiro comum Carioca e Ouro Negro, para plantas hidratadas continuamente (controle) e para plantas submetidos a um déficit hídrico moderado (três dias de seca) no estádio de polinização, com e sem suprimento de Pi foliar, aplicado dois dias antes do déficit hídrico

\begin{tabular}{cccccc}
\hline $\begin{array}{c}\text { Componentes de } \\
\text { produção por planta }\end{array}$ & Pi foliar & \multicolumn{2}{c}{ Carioca } & \multicolumn{2}{c}{ Ouro Negro } \\
& & *irrigado & estressado & irrigado & estressado \\
\hline \multirow{2}{*}{ Número de grãos } & Com Pi & $4,8 \mathrm{a}$ & $5,2 \mathrm{a}$ & $3,5 \mathrm{a}$ & $3,2 \mathrm{a}$ \\
& Sem Pi & $4,3 \mathrm{a}$ & $2,7 \mathrm{~b}$ & $2,2 \mathrm{~b}$ & $3,3 \mathrm{a}$ \\
\multirow{2}{*}{ Número de vagens } & Com Pi & $2,2 \mathrm{a}$ & $2,5 \mathrm{a}$ & $2,9 \mathrm{a}$ & $3,4 \mathrm{Aa}$ \\
& Sem Pi & $2,9 \mathrm{~b}$ & $3,4 \mathrm{a}$ & $2,5 \mathrm{a}$ & $2,4 \mathrm{Ba}$ \\
\multirow{2}{*}{ Peso de grãos } & Com Pi & $2,3 \mathrm{a}$ & $1,3 \mathrm{a}$ & $1,3 \mathrm{a}$ & $1,5 \mathrm{a}$ \\
& Sem Pi & $2,1 \mathrm{a}$ & $1,4 \mathrm{a}$ & $2,0 \mathrm{a}$ & $1,3 \mathrm{a}$ \\
\hline
\end{tabular}

* Os dados são médias de três repetições. Valores seguidos de mesma letra minúscula dentro de cada linha e dentro de cada coluna, não diferiram, valores seguidos com letras maiúsculas diferentes diferiram pelo teste Tukey a $5 \%$.

\subsection{Discussão}

O comportamento diurno, nos genótipos de feijoeiro, foi típico de uma planta anisohídrica (Figura 1). Segundo Tardieu \& Simonneau (1998), a variação diária da $g_{s}$, observada em algumas espécies quando bem hidratadas, é uma resposta à variação das condições atmosféricas e da disponibilidade de água no substrato, e assim essas plantas tendem a reduzir a $g_{s}$, para evitar maiores perdas de água durante as horas de maior demanda do dia. Quando a disponibilidade de água no substrato decrescer, o $\Psi_{f}$ medido antes do amanhecer decresce gradualmente (Figura 2). Os valores de $\Psi_{f}$ não apresentaram diferenças devido ao tratamento com $\mathrm{Pi}$ foliar, contrariamente aos apresentados por Hubhra et al. (2004), que demonstraram a manutenção de um status hídrico superior, nas plantas que receberam um suprimento extra de Pi.

O aumento dos valores de $A$ de plantas de Ouro Negro, sob seca e supridas com Pi foliar, pode ser parcialmente explicado pelo aumento de $g_{s}$ (Chaves et al., 2002; 
Sharkey \& Seemann, 1989), mas provavelmente também seja associado a uma maior exportação de triose-P/Pi na membrana do cloroplasto, a qual pode favorecer a atividade fotossintética (Leegood, 1996) e a abertura estomática. De Groot et al. (2002) demonstraram que, sob déficit hídrico moderado, e antes do rompimento da membrana do cloroplasto, a limitação de Pi pode causar um decréscimo na fotossíntese através de mudanças na atividade de enzimas do ciclo de Calvin, na regeneração da RuBP, e/ou na atividade da rubisco. Assim, pode-se esperar que o aumento na disponibilidade de Pi celular devido ao suprimento extra de Pi foliar, pode aumentar a regeneração da RuBP, e/ou a atividade da rubisco, através de uma maior entrada de Pi no cloroplasto, induzindo um aumento na assimilação de $\mathrm{CO}_{2}$. Portanto, houve uma resposta metabólica da fotossíntese em resposta a um período de seca, como mostrado por Lauer \& Boyer (1992) e Tang et al. (2002). A maior A do Ouro Negro não causou aumento da produção de sementes desta, mas aumentou o número de vagens por planta (Tabela 1), o qual é considerado um importante componente de produção (Fageria et al., 2004), para programas de melhoramento de feijoeiro.

Com o início da seca, $g_{s}$ tende a decrescer mais rápido do que $A$, e assim, a EIUA tende a aumentar como um mecanismo para evitar a desidratação da planta (Chaves et al., 2004). O suprimento de Pi foliar promoveu maior EIUA no horário de maior diferença de pressão de vapor entre a folha e o ar (12:00 h) (Figura 5). Esse parâmetro, portanto, pode ser importante em programas de melhoramento de feijoeiro (Pimentel et al., 1999a), pois a manutenção de um alto turgor, durante a seca, pode garantir a recuperação de $A$ mais rápida, logo após a reidratação. Além disso, a busca por variedades com maior eficiência no uso da água, principalmente em cultivos sem irrigação, se faz necessária, para aumentar a possibilidade de uma produtividade satisfatória sob condições limitantes (Condon et al., 2004).

Todavia, o aumento de $A$ e do número de vagens por planta induzidos pelo suprimento de Pi foliar, antes da deficiência hídrica moderada, foi específico do genótipo Ouro Negro, provavelmente devido às diferenças na eficiência de absorção de fósforo, a qual é muito variável entre genótipos de feijoeiro comum (Fageria et al., 1997). Mais estudos são necessários para a compreensão dessa amenização do efeito do 
déficit hídrico na resposta do metabolismo fotossintético e, consequentemente, na produção ao déficit hídrico por um suprimento extra de Pi foliar em feijoeiro comum. Contudo, uma recomendação agronômica pode resultar deste estudo, que seria realizar adubação nitrogenada no feijoeiro, recomendada aos $25 \mathrm{DAP}$, na forma de fosfato de amônio, ao invés de sulfato de amônio ou uréia, como é o usual principalmente para o cultivo de sequeiro. 


\section{RESPOSTA DAS TROCAS GASOSAS E DA PRODUTIVIDADE À APLICAÇÃO FOLIAR DE FÓSFORO EM Phaseolus vulgaris SOB SECA}

\subsection{Resumo}

Este estudo foi conduzido para avaliar o efeito do suprimento extra de fósforo foliar, nas trocas gasosas e produção, de genótipos de feijoeiro submetidos a déficit hídrico moderado, no estádio de pré-floração. No primeiro experimento, quando o suprimento foliar extra $\left(10 \mathrm{~g} \mathrm{Pi} \mathrm{L}^{-1}\right)$ foi aplicado durante o estresse hídrico ou na recuperação, não houve efeito significativo nas trocas gasosas ou na produção dos genótipos A320, Carioca e Ouro Negro. Contudo, a taxa de assimilação líquida de $\mathrm{CO}_{2}$ (A) de A320 e de Ouro Negro foi menos afetada que em Carioca, no final do período de estresse, quando o Pi foi suprido cinco dias antes do déficit hídrico. No segundo experimento, duas doses diferentes de Pi (Pi10 e Pi20 g Pi L ${ }^{-1}$ ) foram aplicadas cinco dias antes do início da seca, somente no genótipo Carioca. Nos últimos três dias da deficiência hídrica moderada, os valores de $A$ foram significativamente maiores no tratamento Pi20, quando comparado às plantas controle sem suprimento extra de $\mathrm{Pi}$. A eficiência intrínseca do uso da água (EIUA) e o peso seco de sementes das plantas que receberam Pi20, foram maiores em relação aos outros tratamentos.

Termos de indexação: déficit hídrico, feijoeiro comum, fotossínteses, fósforo inorgânico.

\subsection{Summary}

GAS EXCHANGE AND YIELD RESPONSE TO FOLIAR PHOSPHORUS APPLICATION IN Phaseolus vulgaris UNDER DROUGHT 
This study was conducted to evaluate the effect of extra foliar Pi supply on gas exchange and yield of bean genotypes submitted to a mild water deficit at the preflowering stage. In the first essay, when extra Pi $\left(10 \mathrm{~g} \mathrm{Pi} \mathrm{L}^{-1}\right)$ was sprayed during water stress or at recovery, there was no effect of Pi supply on gas exchange or yield in A320, Carioca and Ouro Negro genotypes. However, net $\mathrm{CO}_{2}$ assimilation (A) of A320 and Ouro Negro was less affected, exhibiting higher values than Carioca at the end of the stress, when Pi was supplied five days before water deficit. In the second essay, two different doses of Pi (Pi10 and Pi20 g Pi L ${ }^{-1}$ ) were sprayed five days before water deficit on Carioca leaves. At the last three days of the mild water deficit, $A$ values were significantly higher for the Pi20 treatment when compared to the control plants without extra Pi supply. The intrinsic water use efficiency (IWUE) and for plants seed dry weight per plant receiving Pi20 were higher when considered the other treatments.

Index terms: common bean, photosynthesis, water deficit, inorganic phosphorus.

\subsection{Introdução}

O feijoeiro comum (Phaseolus vulgaris L.) é uma importante cultura alimentícia, que é cultivada sem tecnologia de irrigação na América Latina, onde a seca é um dos maiores fatores limitantes para a produção (Rosales-Serna et al., 2004). Os danos causados pela seca podem ser aumentados quando o déficit hídrico ocorre em um estádio fenológico específico, tal como o de polinização (Pimentel et al., 1999a), reduzindo a produção de feijão em mais de 50\% (Norman et al., 1995). Assim, o feijoeiro é considerado uma cultura muito sensível a seca (Magalhães \& Milhar, 1978; Pimentel et al., 1999b).

De acordo com Westgate \& Boyer (1986), a menor produção das plantas que sofrem deficiência hídrica, no estádio de polinização, é mais relacionada a um efeito indireto da seca sobre a fotossíntese do que a um efeito direto na própria polinização. Neste estádio, a taxa de assimilação de $\mathrm{CO}_{2}(A)$ é maior (Pimentel et al., 1999b) para aumentar a reserva de carboidratos foliar, a qual sustentará o crescimento do embrião 
após a sua fecundação, quando $A$ diminui (Kramer \& Boyer, 1995; Schussler \& Westgate, 1995).

Sob seca, a atividade fotossintética pode ser limitada por fatores estomáticos e não estomáticos. O fechamento estomático é um mecanismo para prevenir a desidratação da planta (Jones, 1985; Laffray \& Loughet, 1990) diminuindo as suas trocas gasosas, mas também ocorre, sob desidratação, uma redução do metabolismo fotossintético, devido ao decréscimo da habilidade do cloroplasto para regenerar a RuBP (Flexas \& Medrano, 2002). Assim, a eficiência intrínseca do uso da água (EIUA), isto é, a taxa de assimilação de $\mathrm{CO}_{2}$ obtida para uma dada condutância estomática $(\mathrm{A} / \mathrm{gs})$, pode ser considerada um relevante parâmetro para a seleção de plantas tolerantes ao déficit hídrico, principalmente entre espécies $\mathrm{C}_{3}$ (Osmond et al., 1980), tal como o feijoeiro (Pimentel et al., 1999b).

O déficit hídrico além de afetar a condutância estomática e o aparato enzimático, também influencia a absorção e a acumulação de fósforo pelas culturas (Mouat \& Nes, 1986). Esse fato tem especial importância, quando consideradas as espécies pobre extratoras de fósforo inorgânico (Pi), como o feijoeiro, cultivadas em solos pobres em fósforo (Fageria et al., 1997). O fósforo é um importante elemento requerido para a atividade fotossintética e transporte de carboidratos (Alam, 1999; Raghothama, 1999). O sistema de transporte antiporte de Pi e triose-P, devido a uma redução na demanda por sacarose pelo dreno (devido à paralização do crescimento sob desidratação), pode causar um aumento na síntese de amido, como redução na assimilação de $\mathrm{CO}_{2}$ no cloroplasto, este efeito pode ser conseqüência da baixa quantidade de Pi reciclado no citoplasma (Stitt \& Quick, 1989; Holbrook \& Keys, 2003). Lawlor \& Cornic (2002) relataram que o suprimento inadequado de Pi ao cloroplasto, devido à redução da exportação de sacarose, pode limitar a síntese de ATP, sendo tal suprimento crucial para manter as reações de fotofosforilação durante a assimilação de $\mathrm{CO}_{2}$, pois o $\mathrm{Pi}$ é recuperado a partir de carboidratos fosforilados no citoplasma, como conseqüência da síntese de sacarose e exportação para outros tecidos (Leegood, 1996).

Portanto, baixo nível de Pi livre citoplasmático, induzido pelo déficit hídrico, associado à acumulação de açúcares fosforilados, pode limitar a produtividade da 
cultura, através da redução da taxa de exportação de triose-P do cloroplasto para o citoplasma (Pieters et al., 2001). O efeito pode ser aumentado no estádio de polinização, quando o conteúdo foliar de carboidratos será crucial para o crescimento reprodutivo e, assim, para a produção (Westgate \& Boyer, 1986; Wardlaw, 1990).

A hipótese testada neste estudo é que o suprimento extra de fósforo (Pi) pode amenizar a limitação induzida pela deficiência hídrica sobre a fotossíntese do feijoeiro, quando aplicado através de pulverização foliar, testando-se diferentes doses em diferentes épocas de aplicação.

\subsection{Material e métodos}

\subsubsection{Material vegetal e condições de crescimento}

Os genótipos de Phaseolus vulgaris L. A320, Carioca e Ouro Negro foram cultivados em potes de $10 \mathrm{~L}$ (uma planta por porte) com $8 \mathrm{~kg}$ de um substrato composto por matéria orgânica misturada com vermiculita expandida (Plantimax - Eucatex Inc., Brasil) na proporção de 3:1. O primeiro e o segundo experimento foram conduzidos paralelamente, utilizando-se 12 potes ( 1 único genótipo x 2 níveis de pulverização foliar x 2 regimes hídricos x 3 repetições) para o primeiro e 108 potes ( 3 genótipos x 2 níveis de pulverização foliar x 3 épocas de aplicação do Pi foliar x 2 regimes de irrigação x 3 repetições) para o segundo experimento. Os potes foram arranjados em blocos inteiramente ao acaso.

Os experimentos foram conduzidos em casa de vegetação, onde a temperatura do ar variou de 10 a $33{ }^{\circ} \mathrm{C}$, para o primeiro e segundo experimento, e de 12 a $38{ }^{\circ} \mathrm{C}$, para o terceiro experimento. Os potes foram adubados com uma dose equivalente de $\mathrm{K}_{2} \mathrm{O}$ (30 $\left.\mathrm{kg} \mathrm{ha}^{-1}\right), \mathrm{P}_{2} \mathrm{O}_{5}\left(90 \mathrm{~kg} \mathrm{ha}^{-1}\right)$ e calcário dolomítico $\left(1500 \mathrm{~kg} \mathrm{ha}^{-1}\right)$, como proposto por Raij (1997), e também com micronutrientes (300 mL de solução de Hoagland), de acordo com McCree (1996). Antes da semeadura, as sementes foram inoculadas com Rhizobium leguminosarum biovar phaseoli (EMBRAPA/CNPAB, Brasil). Uma adubação de cobertura foi realizada aos 25 dias após a emergência (DAE), usando uma dose equivalente a $40 \mathrm{~kg} \mathrm{~N} \mathrm{ha}^{-1}$ uréia solúvel, como proposto por Vieira (1998). 
Nos três experimentos, as plantas foram regularmente irrigadas até o momento de imposição do déficit hídrico, por suspensão da irrigação, quando os genótipos estavam no estádio de pré-floração. Após o tratamento de déficit hídrico, as plantas foram reidratadas e permaneceram irrigadas até o final do ciclo.

\subsubsection{Os tratamentos de déficit hídrico e o suprimento foliar de fósforo}

No primeiro experimento, o genótipo Carioca e, no segundo, os três genótipos (A320, Carioca e Ouro Negro) foram submetidos a um período de deficiência hídrica de 11 dias, no estádio de pré-floração (34 DAE). As plantas foram reidratadas quando o potencial de água da folha ( $\Psi_{f}$ ) alcançou $-0,9 \mathrm{MPa}$, o que é considerado uma deficiência hídrica moderada para o feijoeiro comum (Sharkey \& Seemann, 1989). No primeiro experimento, o principal objetivo foi medir a distribuição de massa seca das plantas sem e com suprimento de Pi foliar, que foi aplicado cinco dias antes da imposição do período de seca. A área foliar foi medida através de um planímetro digital (Li 3100, Licor, Lincoln USA, NE). Após esta medida, as folhas, assim como os ramos e as raízes, foram secos em estufa de ventilação forçada, a $60^{\circ} \mathrm{C}$, até atingir o peso constante.

No segundo experimento, foram utilizados três diferentes tratamentos em relação ao suprimento de Pi foliar: no primeiro tratamento, a pulverização foliar foi realizada cinco dias antes da imposição da seca; no segundo, o suprimento de Pi foliar foi aplicado quando o $\Psi_{f}$ estava em torno de -0,4 MPa (sexto dia do déficit hídrico); e no terceiro, o suprimento de Pi foliar foi aplicado no dia da reidratação, com um $\Psi_{f}$ em torno de $-0,9$ $\operatorname{MPa}\left(11^{\circ}\right.$ dia de seca).

No terceiro experimento, com somente o genótipo Carioca, houve somente uma época de aplicação, com duas doses de Pi, que foram aplicadas cinco dias antes da imposição do déficit hídrico. A seca foi imposta no estádio de pré-floração (34 DAE) durante 10 dias, e as plantas foram reidratadas quando o $\Psi_{f}$ estava em torno de $-0,8$ $\mathrm{MPa}$, também caracterizando uma deficiência hídrica moderada.

\subsubsection{Suprimento de fósforo e conteúdo foliar}


O tratamento com um suprimento foliar extra de Pi, nos três experimentos, foi realizado através de uma pulverização foliar, com uma solução contendo fosfato de monoamonio $\left(\left(\mathrm{NH}_{4}\right) \mathrm{H}_{2} \mathrm{PO}_{4}\right)$. As plantas controle foram supridas com uréia $\left(\left(\mathrm{NH}_{2}\right)_{2} \mathrm{CO}\right)$, para balancear o efeito do nitrogênio nas plantas nas plantas supridas com Pi.

No primeiro e no segundo experimentos, somente uma concentração de Pi foi usada $\left(10 \mathrm{~g} \mathrm{Pi} \mathrm{L}^{-1}\right)$, e as plantas controle foram pulverizadas com 2,64 $\mathrm{g} \mathrm{N} \mathrm{L}^{-1}$. Todas as soluções foram preparadas de acordo com Teixeira \& Araújo (1999).

No terceiro experimento, duas concentrações de Pi foram usadas: $10 \mathrm{~g} \mathrm{Pi} \mathrm{L}^{-1}$ (Pi10) e $20 \mathrm{~g} \mathrm{Pi} \mathrm{L}^{-1}$ (Pi20). Neste experimento foram usados dois tratamentos controle: $\mathrm{N} 10\left(2,64 \mathrm{~g} \mathrm{~N} \mathrm{~L}^{-1}\right)$ e $\mathrm{N} 20\left(5,28 \mathrm{~g} \mathrm{~N} \mathrm{~L}^{-1}\right)$. O conteúdo de fósforo foliar foi quantificado de acordo com Malavolta et al. (1997), no dia zero do déficit hídrico (cinco dias após a pulverização com Pi), em folhas de mesma idade daquelas onde as trocas gasosas foram medidas.

\subsubsection{Trocas gasosas, potencial da água da folha e componentes de produção}

As medidas de taxa de assimilação de $\mathrm{CO}_{2}(A)$ e de condutância estomática $\left(g_{s}\right)$ foram realizadas com um analisador de gases por infravermelho, operando em sistema aberto, com uma câmara foliar de $6 \mathrm{~cm}^{2}$ (LI-6400, LICOR, Lincoln, NE, USA). As medidas foram realizadas no folíolo do meio, da terceira folha totalmente expandida, contada a partir do ápice da planta. O LI-6400 foi zerado diariamente usando ar livre de $\mathrm{CO}_{2}$ e $\mathrm{H}_{2} \mathrm{O}$.

No primeiro e no segundo experimentos, as medidas de trocas gasosas foram feitas entre 09:00 e 10:30 h, sob uma densidade de fluxo de fóton fotossintéticos (DFFF) de $800 \mu \mathrm{mol} \mathrm{m} \mathrm{m}^{-2} \mathrm{~s}^{-1}$. As outras condições microclimáticas, prevalecentes na câmara foliar, foram as mesmas da atmosfera externa. No terceiro experimento, as trocas gasosas foram medidas entre 09:00 e 10:30 h, 12:00 e 13:30 h e 15:00 e 16:30 h, sob

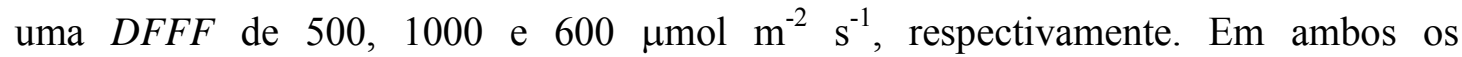
experimentos, a concentração do $\mathrm{CO}_{2}$ do ar dentro da câmara de medidas foi mantido em torno de $370 \mu \mathrm{mol} \mathrm{mol}{ }^{-1}$. A eficiência intrínseca do uso da água (EIUA) foi calculada através da relação $A / g s$ (Osmond et al., 1980). 
A tensão da água no xilema foi medida diariamente, com uma câmara de pressão de Scholander (Soilmoisture Equipment Corp., Santa Bárbara, CA, USA), na quarta folha trifoliolada, contada a partir da base da planta, que era uma folha madura, mas não senescente. Essas medidas foram assumidas como sendo equivalentes ao potencial da água da folha $\left(\Psi_{f}\right)$.

No final do ciclo das plantas, os efeitos de ambos os tratamentos, o déficit hídrico e o suprimento foliar de Pi, foram avaliados nos componentes de produção: peso de sementes por planta e o número de vagens por planta.

\subsubsection{Análise estatística}

Os dados foram submetidos à análise de variância (ANOVA), e as médias foram comparadas pelo teste de Tukey a 0,05 de probabilidade, quando alguma significância foi detectada.

\subsection{Resultados}

\subsubsection{Experimento I: Suprimento foliar de fósforo: trocas gasosas e distribuição de massa seca}

As medidas de trocas gasosas não apresentaram diferenças significativas, devido à aplicação de Pi foliar (Figura 1). No entanto, o déficit hídrico moderado (em torno de 1,0 MPa) foi suficiente para reduzir os valores de $A$ e $g_{s}$ próximos de zero a partir do oitavo dia de seca (Figura 1).

Quanto aos parâmetros de distribuição de massa seca, entre tratamentos irrigado e seco, a área foliar (AF), das plantas sob seca e sem $\mathrm{Pi}$, foi menor $(\mathrm{p}<0,05)$ do que o controle irrigado, mas as plantas sob seca e com Pi não diferiram $(\mathrm{p}>0,05)$ dos demais 


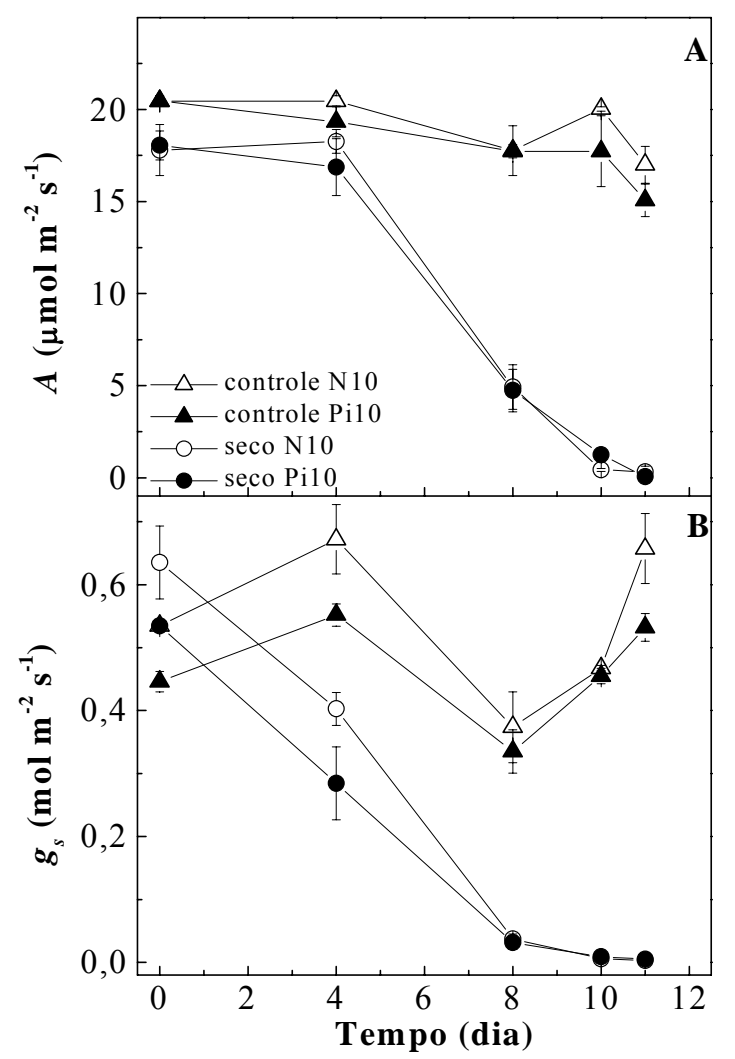

Figura 1 - Taxa de assimilação líquida de $\mathrm{CO}_{2}(A)$ e comdutância estomática $\left(g_{s}\right)$ do genótipo Carioca submetido a onze dias de déficit hídrico. As folhas foram pulverizadas com $10 \mathrm{~g} \mathrm{Pi} \mathrm{L} \mathrm{L}^{-1}$ (Pi10, símbolos fechados) ou 2,64 g N L-1 (N10, símbolos abertos) cinco dias antes da suspensão da irrigação, em plantas controle (triângulos), irrigadas continuamente, e em plantas sob seca (círculos). As medidas foram realizadas entre as 09:00-10:30 h. Cada ponto representa o valor médio \pm erro padrão $(n=3)$

tratamentos (Figura 2A). A massa seca de folhas, nas plantas sob seca, foi menor do que nas plantas controle irrigadas $(\mathrm{p}<0,05)$, para ambos os tratamentos sob seca (sem e com Pi) (Figura 2B). A massa seca de ramos, nas plantas sob seca e com Pi, foi superior $(p<0,05)$ do que a testemunha seca sem Pi (seca N10), mas no entanto não diferiu dos demais tratamentos (controle irrigado) (Figura 2C). A massa seca de raízes não apresentou diferença entre todos os tratamentos ( $p>0,05)$ (Figura 2D), embora as plantas com Pi sob seca tenham demonstrado ter investido no crescimento radicular durante o período de seca. 


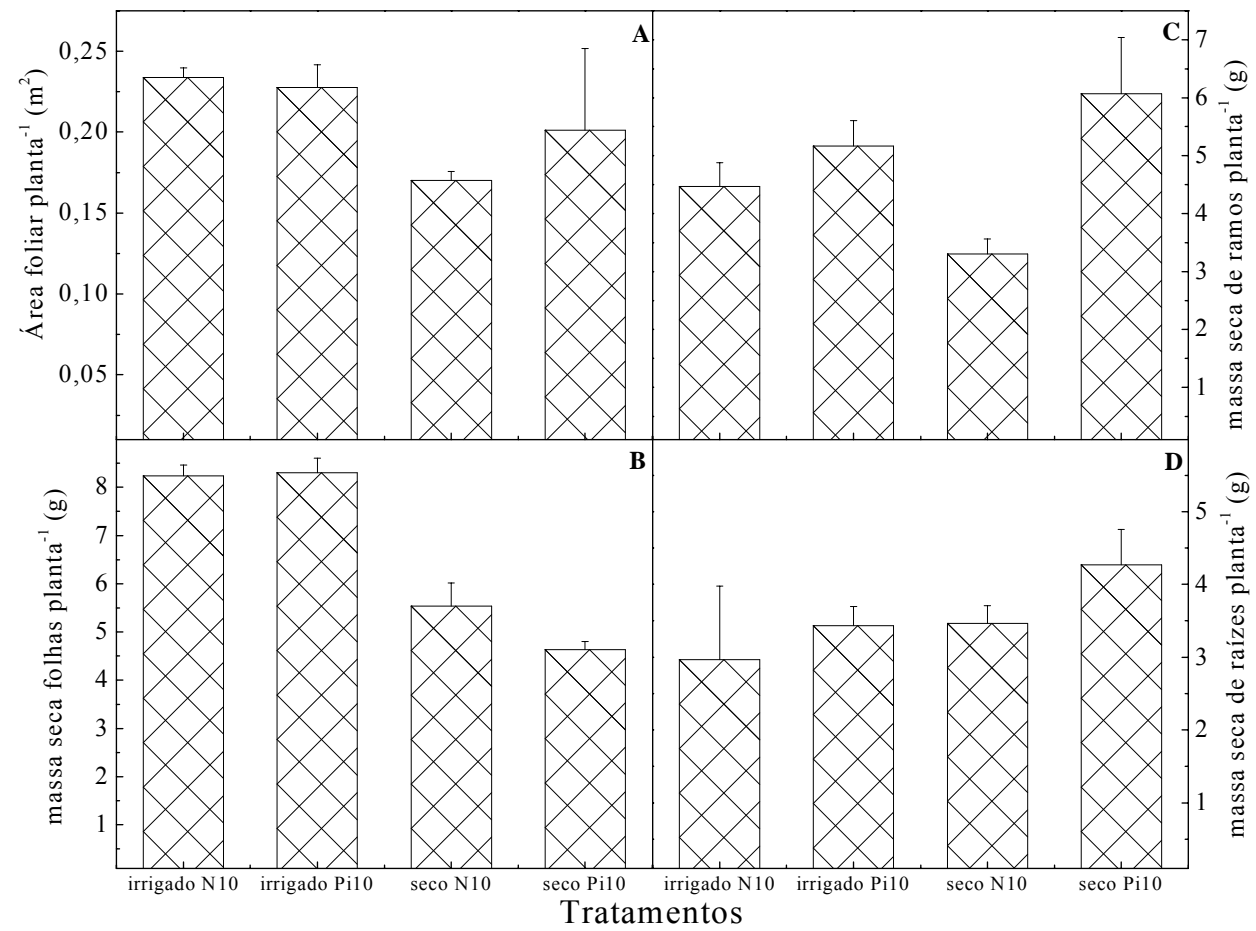

Figura 2 - Área foliar, massa seca de ramos, folhas e raízes do genótipo de feijoeiro (Carioca), submetido a onze dias de déficit hídrico, no estádio de préfloração. As folhas foram pulverizadas com $10 \mathrm{~g} \mathrm{Pi} \mathrm{L}^{-1}$ (Pi10) ou 2,64 $\mathrm{g} \mathrm{N} \mathrm{L}^{-1}$ (N10) cinco dias antes da suspensão da irrigação. Cada barra representa o valor médio \pm erro padrão $(n=3)$

\subsubsection{Experimento II: suprimento foliar de fósforo em diferentes épocas}

No $11^{\circ}$ dia após a imposição da deficiência hídrica (Figura 3), quando as plantas foram reidratadas, o potencial de água da folha ( $\Psi_{f}$ ) estava em torno de $-0,9 \mathrm{MPa}$, caracterizando um déficit hídrico moderado (Sharkey \& Seemann, 1989). 
Neste experimento, o suprimento foliar extra de Pi não afetou significativamente o $\Psi_{f}$ nos genótipos. Além disto, a condutância estomática $\left(g_{s}\right)$ não foi significativamente afetada pelo Pi foliar, em quaisquer dos genótipos (dados não mostrados), sendo a $g_{s}$ reduzida pelo déficit hídrico em 92,90 , e $94 \%$ no $11^{\circ}$ dia de seca para A320, Carioca, e Ouro Negro respectivamente.

A assimilação líquida de $\mathrm{CO}_{2}(A)$ do $\mathrm{A} 320$ e do Ouro Negro foi menos afetada, quando o Pi foliar foi aplicado cinco dias antes da imposição do déficit hídrico. Neste tratamento, ambos os genótipos (A320 e Ouro Negro) mostraram maiores valores de $A$ do que o Carioca, no $8^{\circ}$ e $10^{\circ}$ dia de seca (Figura 4A, D, G). As plantas supridas com Pi foliar apresentaram maiores valores de $A$ no final da recuperação, quando o Pi foi aplicado cinco dias antes da imposição da seca (Figura 4A, D, G).

No segundo experimento, o suprimento extra de Pi foliar, aplicado no último dia do déficit hídrico ( $11^{\circ}$ dia), não teve efeito significativo sobre $A$ nos genótipos estudados (Figura 4C, F, I). Embora as plantas supridas com Pi tenham apresentado maior $A$ durante e/ou após o período de déficit hídrico, o Pi foliar não aumentou nenhum dos componentes de produção (dados não apresentados).

\subsubsection{Experimento III: concentrações diferentes no suprimento foliar de fósforo}

O $\Psi_{f}$ do genótipo Carioca decresceu durante a deficiência hídrica, até atingir - 0,8 $\mathrm{MPa}$, no $10^{\circ}$ dia (Figura 5). Como no primeiro e no segundo experimentos, não houve alteração nas trocas gasosas de plantas bem hidratadas, assim como na $g_{s}$ das plantas sob seca (dados não mostrados). Entretanto, as folhas sob seca e pulverizadas com Pi20 exibiram maiores valores de $A(\mathrm{p}<0,05)$ às 09:00 $\mathrm{h}$, no $8^{\circ}, 9^{\circ}$ e $10^{\circ}$ dia de déficit hídrico (Figura 6D), e às 12:00 h, a partir do $8^{\circ}$ até o $10^{\circ}$ dia de deficiência hídrica (Figura 6D, E), assim como no segundo dia de reidratação (Figura 6E).

A eficiência intrínseca do uso da água (EIUA) no último dia de seca $\left(10^{\circ}\right.$ dia de estresse), às 15:00 h, foi maior nas folhas supridas com a dose $\mathrm{Pi2} 2(\mathrm{p}<0,01)$ do que nos outros tratamentos (N10, Pi10 e N20), como mostrado na Tabela 1. Considerando os componentes de produção, das plantas do genótipo Carioca pulverizadas com Pi foliar e sob déficit hídrico, a massa seca das sementes foi maior no tratamento Pi20 (Tabela 2). 


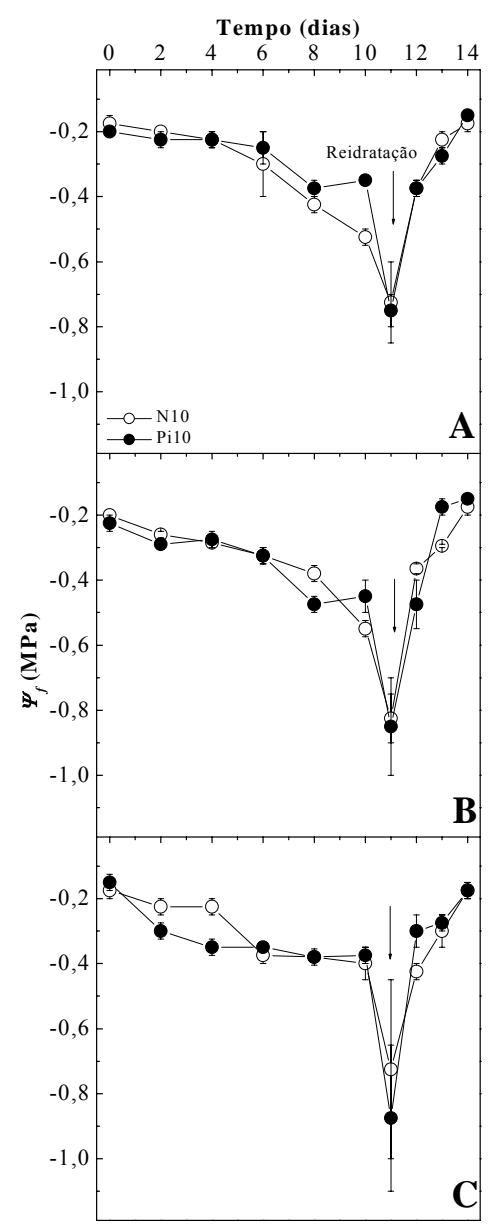

Figura 3 - Valores do potencial de água na folha ( $\Psi_{f}$ ) antes do amanhecer, em genótipos de feijoeiro, A320 (A), Carioca (B), e Ouro Negro (C), submetidos a onze dias de déficit hídrico, no estádio de pré-floração, e três dias de reidratação. As folhas foram pulverizadas com $10 \mathrm{~g} \mathrm{P} \mathrm{L}^{-1}$ (Pi10, círculo fechado) ou 2,64 $\mathrm{g} \mathrm{N} \mathrm{L}^{-1}$ (N10, círculo aberto). Cada ponto representa o valor médio \pm erro padrão $(n=3)$ 


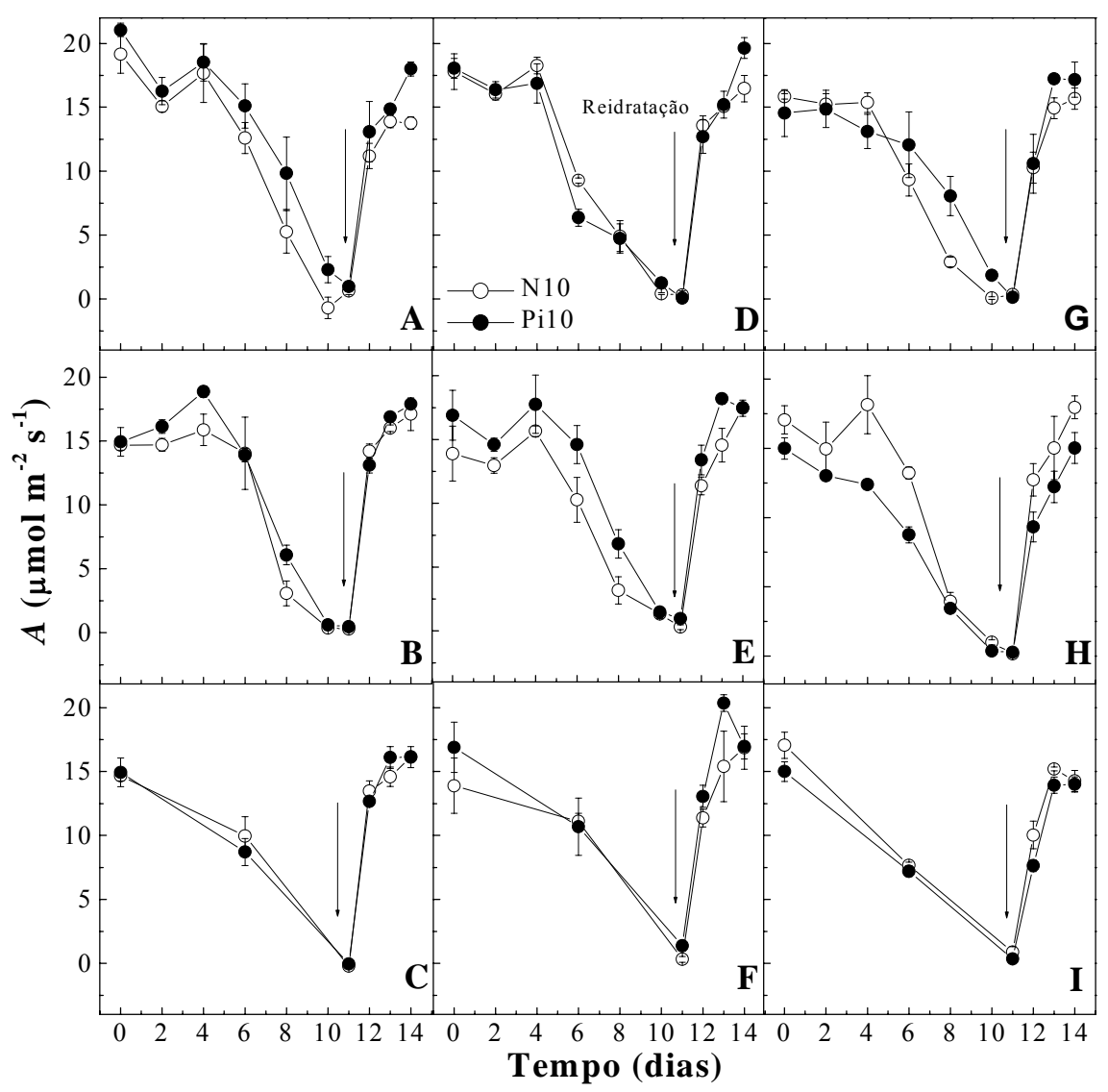

Figura 4 - Taxa de assimilação de $\mathrm{CO}_{2}(A)$ de genótipos de feijoeiro, A320 (a-c), Carioca (d-f), e Ouro Negro (g-i), submetidos a onze dias de déficit hídrico e três dias de reidratação. As folhas foram pulverizadas com $10 \mathrm{~g} \mathrm{P} \mathrm{L}^{-1}$ (Pi10, círculo fechado) ou 2,64 $\mathrm{g} \mathrm{N} \mathrm{L}^{-1}$ (N10, círculo aberto), em diferentes épocas: cinco dias antes da suspensão da irrigação $(\mathrm{A}, \mathrm{D}, \mathrm{G})$; no $6^{\circ}(\mathrm{B}, \mathrm{E}, \mathrm{H})$ e no $11^{\circ}$ (C, F, I) dias de déficit hídrico. A temperatura média diária variou 16,5 a 26,0 ${ }^{\circ} \mathrm{C}$. Cada ponto representa a média \pm erro padrão $(n=3)$ 


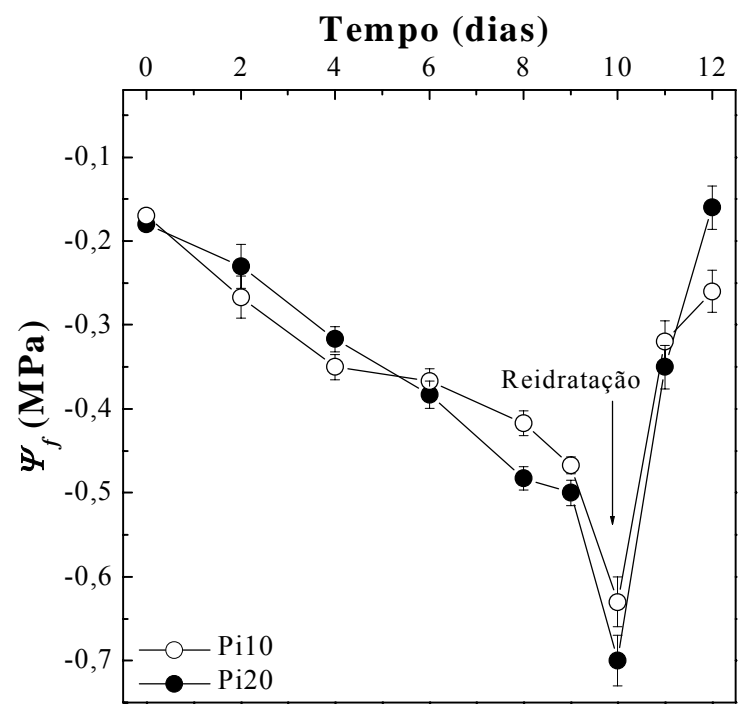

Figura 5 - Valores do potencial de água da folha antes do amanhecer $\left(\Psi_{f}\right)$, do genótipo Carioca submetido a dez dias de déficit hídrico e dois dias de reidratação. As folhas foram pulverizadas com $10 \mathrm{~g} \mathrm{P} \mathrm{L}^{-1}$ (Pi10, círculos abertos) ou $20 \mathrm{~g} \mathrm{P}$ $\mathrm{L}^{-1}$ (Pi20, círculos fechados) cinco dias antes do início da seca. Cada ponto representa a média \pm erro padrão $(n=3)$ 


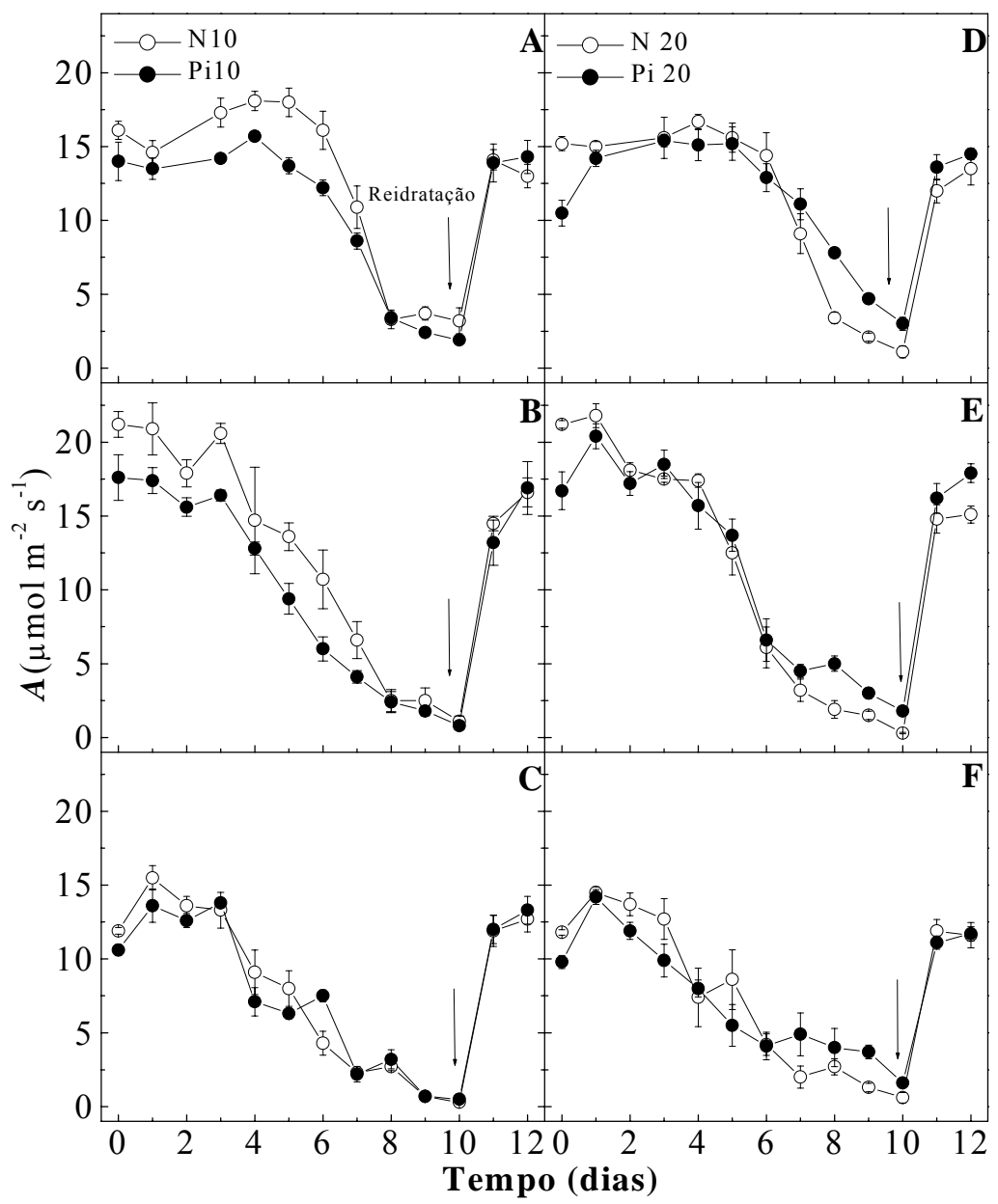

Figura 6 - Taxa de assimilação de $\mathrm{CO}_{2}(A)$ do genótipo de feijoeiro Carioca submetido a dez dias de déficit hídrico e dois dias de reidratação. As folhas foram pulverizadas com $10 \mathrm{~g} \mathrm{P} \mathrm{L}^{-1}$ (Pi10, círculos fechados em A-C) ou 2,64 $\mathrm{g} \mathrm{N} \mathrm{L}^{-1}$ (N10, círculos abertos em A-C); $20 \mathrm{~g} \mathrm{Pi} \mathrm{L}^{-1}$ (Pi20, círculos fechados, em D-F) ou 5,28 $\mathrm{g} \mathrm{N} \mathrm{L}^{-1}$ (N20, círculos abertos em D-F) cinco dias antes da suspensão da irrigação. As medidas foram realizadas entre 09:00-10:30 h (A, D), 12:0013:30 h (B, E) e 15:00-16:30 h (C, F). A temperatura média diária variou 18,8 a $22,8{ }^{\circ} \mathrm{C}$. Cada ponto representa a média \pm erro padrão $(n=3)$ 
Tabela 1. Eficiência intrínseca do uso da água (EIUA), $\mathrm{A} / \mathrm{g}_{\mathrm{s}}\left[\mu \mathrm{mol} \mathrm{CO}_{2}\left(\mathrm{~mol} \mathrm{H}_{2} \mathrm{O}\right)^{-1}\right]$, do genótipo de feijoeiro Carioca com suprimento foliar de $10 \mathrm{~g} \mathrm{Pi} \mathrm{L}^{-1}$ (Pi10) ou 20 g Pi L ${ }^{-1}$ (Pi20), aplicados cinco dias antes da suspensão da irrigação. A EIUA foi calculada a partir das trocas gasosas medidas às 09:00-10:30, 12:00-13:30, e 15:00-16:30 h, dez dias após o início da seca (estresse máximo) e dois dias após a reidratação

\begin{tabular}{ccccccccc}
\hline \multirow{2}{*}{ Hora } & \multicolumn{3}{c}{ Estresse máximo } & \multicolumn{4}{c}{ Após a recuperação } \\
& $\mathrm{N} 10$ & Pi10 & N20 & Pi20 & N10 & Pi10 & N20 & Pi20 \\
\hline $09: 00$ & $91.54 \mathrm{a}$ & $78.38 \mathrm{ab}$ & $61.26 \mathrm{~b}$ & $91.97 \mathrm{a}$ & $21.96 \mathrm{a}$ & $12.58 \mathrm{a}$ & $19.99 \mathrm{a}$ & $19.31 \mathrm{a}$ \\
$12: 00$ & $61.23 \mathrm{a}$ & $45.60 \mathrm{ab}$ & $21.99 \mathrm{~b}$ & $73.95 \mathrm{a}$ & $21.09 \mathrm{a}$ & $17.20 \mathrm{ab}$ & $14.31 \mathrm{~b}$ & $18.36 \mathrm{ab}$ \\
$15: 00$ & $29.31 \mathrm{~b}$ & $44.17 \mathrm{~b}$ & $26.01 \mathrm{~b}$ & $84.60 \mathrm{a}$ & $23.33 \mathrm{ab}$ & $17.33 \mathrm{~b}$ & $27.06 \mathrm{ab}$ & $31.67 \mathrm{a}$
\end{tabular}

Médias na mesma linha seguida de mesma letra não diferiram estatisticamente pelo teste Tukey $(\mathrm{P}>0.05)$. Os dados representam o valor médio $(n=4)$. 
Tabela 2. Componentes de produção (número de vagens por planta e massa seca de sementes por planta) do genótipo de feijoeiro Carioca submetido a déficit hídrico, e suprido com $10 \mathrm{~g} \mathrm{Pi} \mathrm{L}^{-1}$ (Pi10), $20 \mathrm{~g} \mathrm{Pi} \mathrm{L}^{-1}$ (Pi20), 2,64 g N L (N10) or 5,28 $\mathrm{g} \mathrm{N} \mathrm{L}^{-1}$ (N20) cinco dias antes da suspensão da irrigação.

\begin{tabular}{lccc}
\hline $\begin{array}{c}\text { Componentes de produção } \\
\text { por planta }\end{array}$ & Pi foliar & \multicolumn{2}{c}{ Regime hídrico $^{\mathbf{a}}$} \\
& & Irrigado & estressado \\
\hline \multirow{2}{*}{ Número de vagens } & Pi10 & $29.7 \mathrm{Aa}$ & $15.7 \mathrm{Ab}$ \\
& $\mathrm{N} 10$ & $37.0 \mathrm{Aa}$ & $18.7 \mathrm{Ab}$ \\
& $\mathrm{Pi} 20$ & $31.7 \mathrm{Aa}$ & $25.3 \mathrm{Ab}$ \\
& $\mathrm{N} 20$ & $34.0 \mathrm{Aa}$ & $21.3 \mathrm{Ab}$ \\
Massa de sementes & Pi10 & $46.4 \mathrm{Aa}$ & $26.0 \mathrm{Bb}$ \\
& $\mathrm{N} 10$ & $46.8 \mathrm{Aa}$ & $26.4 \mathrm{Bb}$ \\
& $\mathrm{Pi} 20$ & $45.5 \mathrm{Aa}$ & $33.6 \mathrm{Ab}$ \\
& $\mathrm{N} 20$ & $46.8 \mathrm{Aa}$ & $29.3 \mathrm{ABb}$
\end{tabular}

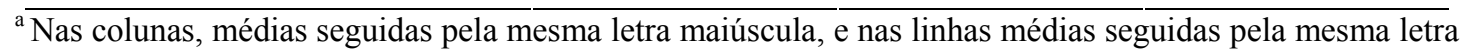
minúscula não diferiram estatisticamente pelo teste Tukey $(\mathrm{P}>0.05)$. Os dados representam o valor médio $(n=4)$.

\subsection{Discussão}

O acúmulo de biomassa é considerado uma importante característica para se alcançar alta produtividade de grãos em leguminosas (Rosales-Serna et al., 2004). O déficit hídrico afeta quase todos os aspectos do crescimento da parte aérea e da raiz, o que leva a uma redução na expansão celular, condutância estomática, fotossíntese e como conseqüência, no acúmulo de matéria seca (Hsiao, 1990).

No primeiro experimento, a aplicação foliar de Pi não alterou as trocas gasosas tanto em plantas irrigadas quanto em plantas secas (Figura 1A, B). No entanto, o suprimento de Pi foi capaz de manter o desenvolvimento de ramos nas plantas sob déficit hídrico $(\mathrm{p}<0,05)$, quando comparadas às testemunhas sem Pi sob seca (Figura 2C). Resultados com feijoeiro comum mostraram que o número de vagens e a massa seca da parte aérea são as características da planta mais importantes para o aumento da 
produção, parâmetros que explicam 95 e $87 \%$, respectivamente, da variabilidade da produção de grãos (Fageria et al., 2004). Sob seca, a cultivar de feijoeiro comum que apresenta maior acúmulo de massa na parte aérea exibe também maior produção de grãos (Rosales-Serna et al., 2004).

O déficit hídrico pode decrescer a absorção de Pi a partir do solo (Mouat \& Nes, 1986), reduzindo a disponibilidade de Pi foliar, para ser usado pelo transportador de $\mathrm{Pi} /$ triose-P, prejudicando então o metabolismo fotossintético no cloroplasto (Leegood, 1986; Flügge et al., 2003). Ao mesmo tempo, um aumento da concentração dos intermediários fosforilados pode ocorrer no citoplasma e no vacúolo, diminuindo os teores de Pi livre, o que representa uma limitação adicional ao metabolismo fotossintético. O suprimento de Pi foliar em plantas bem hidratadas não afetou a taxa de assimilação de $\mathrm{CO}_{2}(A)$, nos quatro dias seguintes de medidas (dados não apresentados). Isto ocorreu provavelmente devido ao contínuo crescimento e exportação de fotoassimilados em plantas bem hidratadas, que possivelmente apresentaram reserva de Pi vacuolar, a qual pode ser usada quando o conteúdo de Pi citossólico estiver reduzido (Sivak \& Walker, 1986; Mimura, 2001).

Durante a deficiência hídrica moderada induzida no segundo ensaio (as plantas foram reidratadas quando $\Psi_{f}$ atingiu $-0,9 \mathrm{MPa}$ ), quando os genótipos A320, Carioca e Ouro Negro estavam no estádio de pré-floração, $\Psi_{f,} g_{s}$ e $A$ não foram afetados pelo suprimento foliar de Pi. O suprimento foliar extra de Pi foliar induziu mudanças na taxa fotossintética, somente quando este foi pulverizado antes da seca. 
Tabela 3. Conteúdo foliar de fósforo de genótipos de feijoeiro, sem suprimento foliar (controle) e com suprimento foliar de $10 \mathrm{~g} \mathrm{Pi} \mathrm{L}^{-1}$ (Pi10) ou de $20 \mathrm{~g} \mathrm{Pi} \mathrm{L}^{-1}$ (Pi20), aplicados cinco dias antes da coleta das folhas (As amostras foram coletadas no primeiro dia de seca)

\begin{tabular}{clccc}
\hline \multirow{2}{*}{ Experimento } & Genótipos & \multicolumn{3}{c}{ Conteúdo de fósforo $^{*}$} \\
& & \multicolumn{2}{c}{ [g (100 g massa seca) ${ }^{-1}$ ] } & \\
& controle & Pi10 & Pi20 \\
\hline \multirow{2}{*}{ I } & A320 & 0,56 & 0,67 & - \\
& Carioca & 0,44 & 0,64 & - \\
II & Ouro Negro & 0,45 & 0,69 & - \\
& Carioca & 0,65 & 0,74 & 0,89 \\
\hline
\end{tabular}

*Os dados representam o valor médio $(\mathrm{n}=4)$.

Em geral, o feijoeiro tem dois mecanismos principais para adaptação ao déficit hídrico: o controle estomático (Laffray \& Louguet, 1990; Pimentel et al., 1999b) e o desenvolvimento do sistema radicular (Kuruvadi \& Aguilera, 1990). Embora não tenha havido efeito do suprimento foliar extra de Pi sobre $g_{s}$ das plantas de feijoeiro sob déficit hídrico, maiores valores de $A$ foram verificados sob déficit hídrico em plantas supridas com a solução de Pi20 (Figura 6D-F), bem como maiores valores de EIUA $(\mathrm{p}<0,01)$ em plantas do tratamento Pi20 na máxima deficiência hídrica (Tabela 1). Entretanto, a reduzida $g_{s}$ em um genótipo eficiente fotossinteticamente pode minimizar a transpiração foliar, aumentando a EIUA, e mantendo o crescimento e a produção da planta (Ehleringer, 1990; Pimentel et al., 1999a). Como apontado por Pimentel et al. (1999a), a alta EIUA sob déficit hídrico, especialmente no estádio de polinização, pode ser usada como um parâmetro fisiológico em programas de melhoramento de feijoeiro, para seleção de genótipos tolerantes à seca.

Os resultados mostraram que a solução Pi20 pode promover uma redução dos danos causados à $A$ pela seca no estádio de pré-floração, aumentando o conteúdo de $\mathrm{Pi}$ foliar (Tabela 3) e, conseqüentemente, a massa seca de sementes por planta $(\mathrm{p}<0,05)$ (Tabela 2). Sob déficit hídrico, Mouat \& Nes (1986) e Alam (1999) observaram baixo 
conteúdo de Pi foliar em plantas sob deficiência hídrica, devido à redução na absorção de Pi a partir do solo. Visto que houve um alto conteúdo de Pi foliar, nas plantas supridas com Pi (Tabela 3), pode ser sugerido que a maior disponibilidade de Pi é um dos fatores que induziram maiores valores de $A$ em plantas sob seca, especialmente no tratamento Pi20 (Figura 6D-F).

O déficit hídrico causou reduções no número de vagens e massa de sementes por planta (Tabela 2). Essas conseqüências negativas, da seca sobre a produção da planta, foram reduzidas nas plantas do tratamento Pi20, que apresentaram menor decréscimo no número de vagens (20\%) e massa seca de sementes (26\%), quando comparado com Pi10 (47 e 43\%, respectivamente), N10 (37 e 49,5\%, respectivamente) e as plantas supridas com N20 (37 e 43\%, respectivamente). Contudo, mais estudos são necessários para compreender o efeito do Pi sobre o metabolismo fotossintético e a produção em genótipos de feijoeiro comum sob déficit hídrico, quando eles recebem um suprimento extra de Pi, via foliar. Mesmo não havendo efeito significativo da aplicação foliar de Pi nos componentes da produção, poderia-se recomendar o uso do fosfato de amônio na adubação de cobertura do feijoeiro, indicada aos 25 DAE, ao invés do uso de uréia ou sulfato de amônio, como é feito tradicionalmente. 


\section{APLICAÇÃO FOLIAR DE FÓSFORO, TROCAS GASOSAS E FLUORESCÊNCIA DA CLOROFILA, EM GENÓTIPOS DE FEIJOEIRO COMUM SUBMETIDOS A UM DÉFICIT HÍDRICO MODERADO.}

\subsection{Resumo}

Este estudo foi conduzido para avaliar o efeito do suprimento extra de fósforo foliar em dois genótipos de feijoeiro, A320 e Ouro negro, submetidos a déficit hídrico moderado, no estádio de pré-floração. As plantas foram cultivadas em potes, na casa de vegetação, e metade delas recebeu um suprimento extra de $10 \mathrm{~g} \mathrm{Pi} \mathrm{L}^{-1}$, dois dias antes da imposição da seca, aos 32 DAP. A taxa de assimilação de $\mathrm{CO}_{2}(A)$ foi menos reduzida, com a imposição do estresse, em A320, com e sem Pi, que no Ouro Negro, até o quarto dia de seca, e na reidratação, $A$ e a condutância estomática $\left(g_{s}\right)$ de A320 com Pi foram superiores aos valores das plantas sem Pi. O potencial fotossintético $\left(A_{c}\right)$ de Ouro negro com Pi foi superior ao de A 320, com e sem Pi, na seca máxima, e ao A320 sem Pi, na reidratação. A dissipação térmica, não fotoquímica (NPQ), do genótipo A320 sem Pi foi maior que com Pi e que a do Ouro Negro, com e sem Pi, na reidratação, provavelmente devido aos menores valores de $A$ neste tratamento sem Pi. Não houve diferenças no número de vagens e no peso de sementes dos dois genótipos, mas o genótipo A320, com $\mathrm{Pi}$, apresentou quase o dobro do peso de sementes das plantas sem Pi. O uso de fosfato de amônio substituindo a uréia ou o sulfato de amônio, que são aplicados aos 25 DAE, é recomendável.

Termos de indexação: fluorescência da clorofila, estresse sob seca, fósforo inorgânico, Phaseolus vulgaris.

\subsection{Summary}




\section{FOLIAR PHOSPHORUS SUPPLYING GAS EXCHANGE AND CHOROPHILL FLUORESCENCE IN COMMON BEAN GENOTYPES SUBMITTED TO A MILD WATER DEFICIT}

The effect of $10 \mathrm{~g} \mathrm{Pi} \mathrm{L}^{-1}$ foliar supplied two days before a mild water deficit imposed 32 days after sowing (DAS), at pre-flowering stage, was evaluated on two bean genotypes, A 320 and Ouro negro, growing in pots in greenhouse. The $\mathrm{CO}_{2}$ assimilation rate (A) was not severely affected on A 320 until the fourth day of water deficit, and during rehydration $A$ and stomatal conductance $\left(g_{s}\right)$ of A 320 with foliar Pi supply was higher than for it non Pi supplied. The $\mathrm{O} 2$ evolution $\left(A_{c}\right)$ on Ouro negro with extra Pi was higher than for A 320, with or without Pi, at the last day of the mild water deficit, and it was higher than A 320 with extra Pi at rehydration. The non-photosynthetic quenching (NPQ), was higher for A320 without Pi at recovery, probably due to the smaller values of $\mathrm{A}$ at this treatment. There were no significant differences for pod number and seed weight due to extra Pi supply, but the dry weight of A320 with extra Pi supply was almost two fold greater than for no Pi supplied plants. The use of ammonium phosphate, instead of urea or ammonium sulphate to be applied as usual 25 DAS, is recommended.

Index terms: common bean, photosynthesis, water deficit, inorganic phosphorus.

\subsection{Introdução}

O feijoeiro comum (Phaseolus vulgaris L.) é uma importante cultura para alimentação na América Latina, onde é cultivado, na maioria das vêzes, sem o uso da irrigação e, portanto, a seca é a maior limitação para a produção desta leguminosa (Rosales-Serna et al., 2004). Mesmo um déficit hídrico moderado pode causar uma significativa redução na taxa de fotossíntese líquida de plantas de feijoeiro (Sharkey \& Seemann, 1989). Além disso, outro fator freqüente que prejudica a produtividade do feijoeiro em ambiente tropical é a deficiência de fósforo (Pi) nos solos (Mouat \& Nes, 1986; Abel et al., 2002; Wissuwa, 2003), fator que se agrava ao considerar que o feijoeiro é uma planta com baixa capacidade de extrair Pi do solo (Fageria et al. 2004). 
Dessa forma, pode-se considerar que um efeito cinergético entre deficiência hídrica e baixa disponibilidade de fósforo no solo pode ocorrer, aumentando os efeitos da seca sobre a produção do feijoeiro. Os efeitos podem variar entre genótipos de feijoeiro porque eles respondem de forma diferente ao déficit hídrico (Pimentel et al., 1999b; Rosales-Serna et al., 2004) bem como quanto a capacidade de absorção de Pi do solo (Fageria et al., 2004; Parra et al., 2004).

A seca induz uma redução nas taxas de assimilação de $\mathrm{CO}_{2}$ (Sharkey \& Seemann, 1989), bem como na evolução de $\mathrm{O}_{2}$ do feijoeiro comum (Pimentel et al., 1999a). Esses efeitos podem ser parcialmente explicados pela baixa concentração mesofílica de $\mathrm{CO}_{2}$ devido ao fechamento estomático (Chaves et al., 2002). Contudo, Lauer \& Boyer (1992) mostraram que há uma alta concentração interna de $\mathrm{CO}_{2}$, em folhas de feijoeiro, sob baixo potencial de água. Além disso, Tang et al. (2002) trabalhando com discos foliares de girassol, com e sem epiderme (neste último sem limitação estomática das trocas gasosas), também observaram uma limitação não estomática à fotossíntese sob déficit hídrico. De acordo com Tezara et al. (1999), a seca limitou a assimilação de $\mathrm{CO}_{2}$ devido à inibição da síntese de ribulose bifosfato (RuBP), relacionando isto com o baixo conteúdo de ATP, provavelmente devido à redução da atividade da síntese de ATP.

Redução na síntese de ATP no cloroplasto pode ser causada pela redução na exportação de triose-P. Esta limitação pode ser uma conseqüência de uma baixa disponibilidade de fósforo inorgânico (Pi) livre no citoplasma, para ser trocado pela triose-P, a partir do transportador de fósforo (TF) na membrana do cloroplasto, o qual usa o Pi como substrato (Flügge et al., 2003). Sob seca há uma paralisação da exportação de fotoassimilados das folhas e uma acumulação de açúcares fosforilados, especialmente frutose-2,6-bifosfato (Yordanov et al., 2000). Esta molécula regula o sistema de antiporte no TF e sustenta a fosforilação e o ciclo de Calvin, ao regular a importação de Pi e exportação de carbono no cloroplasto (Leegood, 1996; Flügge et al., 2003).

Alguns estudos têm investigado a relação entre o conteúdo de fósforo e o metabolismo fotossintético (Kondracka \& Rychter, 1997; Hendrickson et al., 2004; 
Kozlowska-Szerenos, 2004), todavia nenhum tem estudado o efeito do déficit nesta relação. Nas folhas, a taxa de síntese do produto final (sacarose, amido e aminoácidos) determina a taxa na qual o Pi é reciclado de volta às reações da fotossíntese, no cloroplasto (Paul \& Pellny, 2003). No entanto, a fotorrespiração também pode contribuir para a manutenção da reciclagem de $\mathrm{Pi}$, em folhas com baixa disponibilidade de $\mathrm{Pi}$ (Maleszewski et al., 2004), mas este processo inibe a fotossíntese in vivo, o que foi demonstrado quando o Pi é retirado do meio de crescimento (Pieters et al., 2001). Recentemente, Hendrickson et al. (2004) mostraram que folhas de videira, supridas com $\mathrm{Pi}$, submetidas à baixas temperaturas, exibiram entre 71 e $80 \%$ de aumento da fotossíntese, dependendo das condições ambientais. Portanto, o objetivo do presente trabalho foi avaliar a resposta do aparato fotossintético ao déficit hídrico moderado, em genótipos de feijoeiro comum recebendo um suprimento extra de Pi foliar, antes da imposição da deficiência hídrica.

\subsection{Material e métodos}

\subsubsection{Material vegetal e condições de crescimento}

Este estudo foi conduzido com dois genótipos de feijoeiro Phaseolus vulgaris (L.), A320 e Ouro Negro. A320 é uma linhagem, que mantém alto potencial de água da folha ( $\left.\Psi_{f}\right)$ sob condições de seca (Pimentel et al., 1991), e Ouro Negro é uma nova cultivar de sementes pretas. Os genótipos foram cultivados em potes de $10 \mathrm{~L}$ (uma planta por pote), contendo $8 \mathrm{~kg}$ de uma mistura de material orgânico e vermiculita expandida, em uma proporção de 3:1, respectivamente (Plantimax; Eucatex, Brasil), sob condições de casa de vegetação. Cada pote foi adubado com uma dose equivalente à 20 $\mathrm{kg} \mathrm{NH}_{4} \mathrm{PO}_{4} \mathrm{ha}^{-1}, 30 \mathrm{~kg} \mathrm{~K}_{2} \mathrm{O} \mathrm{ha}^{-1}, 90 \mathrm{~kg} \mathrm{P}_{2} \mathrm{O}_{5} \mathrm{ha}^{-1} \mathrm{e} 1500 \mathrm{~kg} \mathrm{ha}^{-1}$ de calcário dolomítico (Raij et al., 1997), além de $300 \mathrm{~mL}$ de uma solução de micronutrientes (McCree, 1996). Aos 25 dias após a emergência (DAE), realizou-se uma adubação de cobertura com uma dose de uréia equivalente a $40 \mathrm{~kg} \mathrm{ha}^{-1}$, segundo recomendação de Vieira (1998). A irrigação foi realizada diariamente até o início da imposição da seca, e depois na reidratção até o fim do ciclo das plantas. O experimento foi conduzido em uma casa de 
vegetação, onde a temperatura do ar variou de 17,4 a $35,3{ }^{\circ} \mathrm{C}$, durante o tratamento de deficiência hídrica.

\subsubsection{Aplicação foliar de fósforo}

O tratamento com um suprimento extra de Pi foliar foi realizado, através de uma pulverização foliar, com uma solução contendo fosfato de monoamonio $\left(\left(\mathrm{NH}_{4}\right) \mathrm{H}_{2} \mathrm{PO}_{4}\right)$. As plantas controle foram supridas com uréia $\left(\left(\mathrm{NH}_{2}\right)_{2} \mathrm{CO}\right)$, para balancear o efeito do nitrogênio aplicado nas plantas com suprimento de Pi. Foi usado $10 \mathrm{~g} \mathrm{Pi} \mathrm{L}{ }^{-1}$, no tratamento com suprimento extra de $\mathrm{Pi}$, e as plantas controle foram pulverizadas com 2,64 $\mathrm{g} \mathrm{N} \mathrm{L}^{-1}$. Todas as soluções foram preparadas de acordo com Teixeira \& Araújo (1999). As plantas foram pulverizadas, para ambas as soluções e tratamentos (com e sem Pi), dois dias antes da imposição da seca, aos 32 DAE, no estádio de pré-floração.

\subsubsection{Avaliação do potencial da água foliar}

A tensão da água do xilema foi medida diariamente, antes do amanhecer, com uma câmara de pressão de Scholander (Soilmoisture Equipment Corp., Santa Bárbara, CA, USA), na quarta folha trifoliolada, contada a partir da base da planta, uma folha madura mas não senescente. Essas medidas foram assumidas como sendo equivalentes ao potencial da água foliar $\left(\Psi_{f}\right)$.

\subsubsection{Trocas gasosas foliar}

A taxa de assimilação de $\mathrm{CO}_{2}(A)$, a condutância estomática $\left(g_{s}\right)$ e a concentração de $\mathrm{CO}_{2}$ intercelular $\left(C_{i}\right)$ foram avaliadas, com um analisador de gases por infravermelho (LI-6400, LICOR Inc., Lincoln, USA), no folíolo principal da terceira folha trifoliolada, uma folha madura e não senescente, contada a partir do ápice da planta. Essas variáveis foram medidas no início da seca, em plantas bem hidratadas no chamado dia zero do estresse, no quarto, quinto e sétimo dia de seca, bem como no primeiro, segundo e terceiro dia após a reidratação das plantas. Todas as medidas foram realizadas sob uma densidade de fluxo de fótons fotossintético (DFFF) de 1.100 $\mu \mathrm{mol} \mathrm{m}^{-2} \mathrm{~s}^{-1}$, e entre 09:00 e 10:30 h. O ar coletado dentro da casa de vegetação foi passado através de um galão, 
para que a quantidade de $\mathrm{CO}_{2}$ presente neste permanecesse estável, e então era bombeado para dentro do sistema de medidas, com uma concentração de $\mathrm{CO}_{2} \mathrm{em}$ torno de $370 \mu \mathrm{mol}$. $\mathrm{mol}^{-1}$. As outras condições microclimáticas, que prevaleceram dentro da câmara de medida, foram as mesmas da atmosfera na casa de vegetação. Durante as medidas de trocas gasosas, a temperatura foliar variou de 26,2 a $34,8{ }^{\circ} \mathrm{C}$, e a diferença de pressão de vapor entre o ar, nos espaços intercelulares, e a atmosfera variou de 0,8 a 2,5 $\mathrm{kPa}$.

\subsubsection{Liberação de $\mathrm{O}_{2}$ fotossintético}

A taxa de liberação de $\mathrm{O}_{2}$ fotossintético $\left(A_{c}\right)$ foi medida usando um eletrodo de oxigênio tipo -Clark e uma câmara foliar LD2/3 (Hansatech, Norfolk, UK). O DFFF foi provido por uma fonte de luz externa $1.100 \mu \mathrm{mol} \mathrm{m} \mathrm{m}^{-2} \mathrm{~s}^{-1}$ (LS3, Hansatech). Um disco foliar com uma área de $10 \mathrm{~cm}^{2}$ foi colocado dentro da câmara foliar com uma concentração de $\mathrm{CO}_{2}$ saturante, onde o eletrodo de oxigênio foi previamente calibrado, como descrito por Delieu \& Walker (1981). A câmara foi equipada com uma jaqueta de água, para manutenção da temperatura em $35{ }^{\circ} \mathrm{C}$, controlada por um banho maria externo (MA-127, Marconi, Piracicaba, SP Brasil). As medidas foram feitas à $35{ }^{\circ} \mathrm{C}$, devido esta temperatura ser a que predominou durante o horário das medidas de trocas gasosas, na casa de vegetação. A $A_{c}$ foi medida no dia de máximo estresse (sétimo dia de seca), antes da reidratação, e após a recuperação das plantas sob deficiência hídrica (terceiro dia de reidratação).

\subsubsection{Fluorescência da clorofila a}

A fluorescência da clorofila foi medida, simultaneamente à liberação de $\mathrm{O}_{2}$ fotossintético, usando um fluorômetro modulado (FMS 1, Hansatech, Norfolk, UK), acoplado à câmara foliar LD2/3. Antes das medidas, os discos foliares foram mantidos sem iluminação (dentro da câmara LD2/3), durante 10 minutos, a $35{ }^{\circ} \mathrm{C}$. Após este período, a emissão da fluorescência mínima $\left(\mathrm{F}_{\mathrm{o}}\right)$ e máxima $\left(\mathrm{F}_{\mathrm{m}}\right)$ foram medidas, usando o método do pulso saturante (Schreiber, 1986) e os parâmetros descritos por Genty et al. (1989) e Schreiber et al. (1994). A máxima produção de fluorescência $\left(F_{m}\right)$ foi obtida 
com a aplicação de pulso de saturação $\left(18000 \mu \mathrm{mol} \mathrm{m}^{-2} \mathrm{~s}^{-1}\right)$, durante 2,5 segundos, após as medidas de $\mathrm{F}_{\mathrm{o}}$ sob fraca e contínua iluminação modulada (menos de $5 \mu \mathrm{mol} \mathrm{m} \mathrm{m}^{-2}$ ), durante o período de escuro. Após as medições em folhas adaptadas ao escuro, estas foram iluminadas e a emissão de fluorescência no estado estável $\left(\mathrm{F}_{\mathrm{s}}\right)$ e máxima $\left(\mathrm{F}_{\mathrm{m}}{ }^{\prime}\right)$ foram determinadas, nas folhas adaptadas à luz, sob fotossíntese estável (após 6 minutos em $1.100 \mu \mathrm{mol} \mathrm{m} \mathrm{m}^{-2} \mathrm{~s}^{-1}$ ). A emissão de fluorescência variável foi calculada em ambas as condições: de escuro - $\left(\mathrm{F}_{\mathrm{v}}=\mathrm{F}_{\mathrm{m}}-\mathrm{F}_{\mathrm{o}}\right)$ e adaptada à luz $\left(\Delta \mathrm{F}=\mathrm{F}_{\mathrm{m}}\right.$ '- $\left.\mathrm{F}_{\mathrm{s}}\right)$. A emissão de fluorescência mínima $\left(F_{0}{ }^{\prime}\right)$, após a excitação do fotossistema I (PSI) com luz vermelho distante, foi também mensurada.

A partir da medida destas variáveis de fluorescência, foram calculadas: a eficiência quântica potencial $\left(\mathrm{F}_{\mathrm{v}} / \mathrm{F}_{\mathrm{m}}\right)$ e a efetiva $\left(\Delta \mathrm{F}=\mathrm{F}_{\mathrm{m}}{ }^{\prime}\right)$ do fotossistema II (PSII), a taxa de transporte de elétron aparente $\left(\mathrm{ETR}=\Delta \mathrm{F}=\mathrm{F}_{\mathrm{m}}{ }^{\prime} \times\right.$ DFFF $\left.\times 0,5 \times 0,84\right)$, $\mathrm{o}$ coeficiente de extinção fotoquímico $\left[\mathrm{q}_{\mathrm{p}}=\left(\mathrm{F}_{\mathrm{m}}{ }^{\prime}-\mathrm{F}_{\mathrm{s}}\right) /\left(\mathrm{F}_{\mathrm{m}}\right.\right.$ '- $\left.\mathrm{F}_{\mathrm{o}}{ }^{\prime}\right)$ e o não fotoquímico $\left[\mathrm{NPQ}=\left(\mathrm{F}_{\mathrm{m}}-\mathrm{F}_{\mathrm{m}}{ }^{\prime}\right) / \mathrm{F}_{\mathrm{m}}{ }^{\prime}\right]$. Para o cálculo da ETR, 0,5 foi assumido como a fração da excitação da energia distribuída ao PSII e 0,84 como a fração de luz absorvida da folha. Todos estes cálculos foram realizados conforme proposto por Schreiber et al. (1994).

\subsubsection{Componentes da produção}

No final do ciclo das plantas, os efeitos do déficit hídrico e da pulverização de Pi foram avaliados nos componentes de produção: número de vagens por planta e massa de sementes por planta. Esses componentes de produção também foram avaliados em plantas bem hidratadas (com irrigação contínua). Contudo, essas plantas não apresentaram quaisquer mudanças devido ao suprimento de Pi foliar.

\subsubsection{Análise estatística}

O experimento foi arranjado em blocos ao acaso com três repetições. Os dados foram sujeitos a análise de variância (ANOVA), e as médias foram comparadas pelo teste Tukey quando alguma significância $(p<0.05)$ foi detectada.

\subsection{Resultados}




\subsubsection{Potencial da água da folha}

O potencial da água foliar $\left(\Psi_{f}\right)$ decresceu nas plantas sob déficit hídrico em ambos os genótipos, mas no entanto, não foi observado nenhuma diferença entre os genótipos estudados. As plantas estressadas apresentaram valores menores de $\Psi_{f}$ (valores médios de -1,0 MPa) do que as plantas hidratadas (valores médios de -0,25 MPa) no dia de máximo estresse (sétimo dia de seca), quando foram reidratadas. Após a reidratação e o período de recuperação, o $\Psi_{f}$ das plantas submetidas à seca retornou aos valores das plantas controle (dados não apresentados).

\subsubsection{Efeito da seca e da aplicação de Pi foliar sobre as trocas gasosas e a liberação do $\mathrm{O}_{2}$}

Sob déficit hídrico moderado, $A$ foi reduzida em ambos os genótipos (Figura 1A, D). Contudo, os valores de $A$ do A320, com e sem Pi, foram significativamente menos reduzidos, quando comparados aos de Ouro Negro, até o quarto dia de seca. Além disso, as plantas de A320 com Pi apresentaram maiores valores de $A(p<0,05)$ do que as plantas não supridas com $\mathrm{Pi}$, após a recuperação (Figura 1A). Os valores de $g_{s}$ também decresceram durante o déficit hídrico, porém não houve diferenças entre os genótipos (Figura 1B, E). Com a reidratação, o suprimento de Pi permitiu a recuperação dos valores de $g_{s}$, das plantas estressadas do genótipo A320, comparáveis aos das plantas irrigadas continuamente e deste genótipo mas não supridas com $\mathrm{Pi}(\mathrm{p}<0,05)$ (Figura 1B). Por outro lado, a $g_{s}$ do Ouro Negro estressado e suprido com Pi foliar, durante a recuperação, retornou aos valores de antes do início da deficiência hídrica (dois dias antes do estresse), e do dia da suspensão da irrigação (dia zero). Quanto à $C_{i}$, após o início do déficit hídrico, os seus valores decresceram da mesma forma para todos os tratamentos. Contudo, as plantas da cultivar Ouro Negro apresentaram menores valores de $C_{i}$ para ambos os tratamentos ( $\left.>00,05\right)$ ), em relação às plantas de $\mathrm{A} 320$ sob seca.

Quanto à liberação de $\mathrm{O}_{2}$, no dia de estresse máximo, não houve efeito da pulverização de Pi na $A_{c}$ do genótipo A320. Todavia, neste dia, o Ouro Negro com Pi foliar apresentou maiores valores de $A_{c}$ do que o A320, com e sem Pi foliar $(p<0,01)$. Já 
na reidratação, a aplicação de Pi aumentou a $A_{c}$ em ambos os genótipos, mas que foi significativa somente para Ouro Negro e A320, com Pi, em relação à A320 sem Pi $(\mathrm{p}<0,01)$ (Tabela 1). 


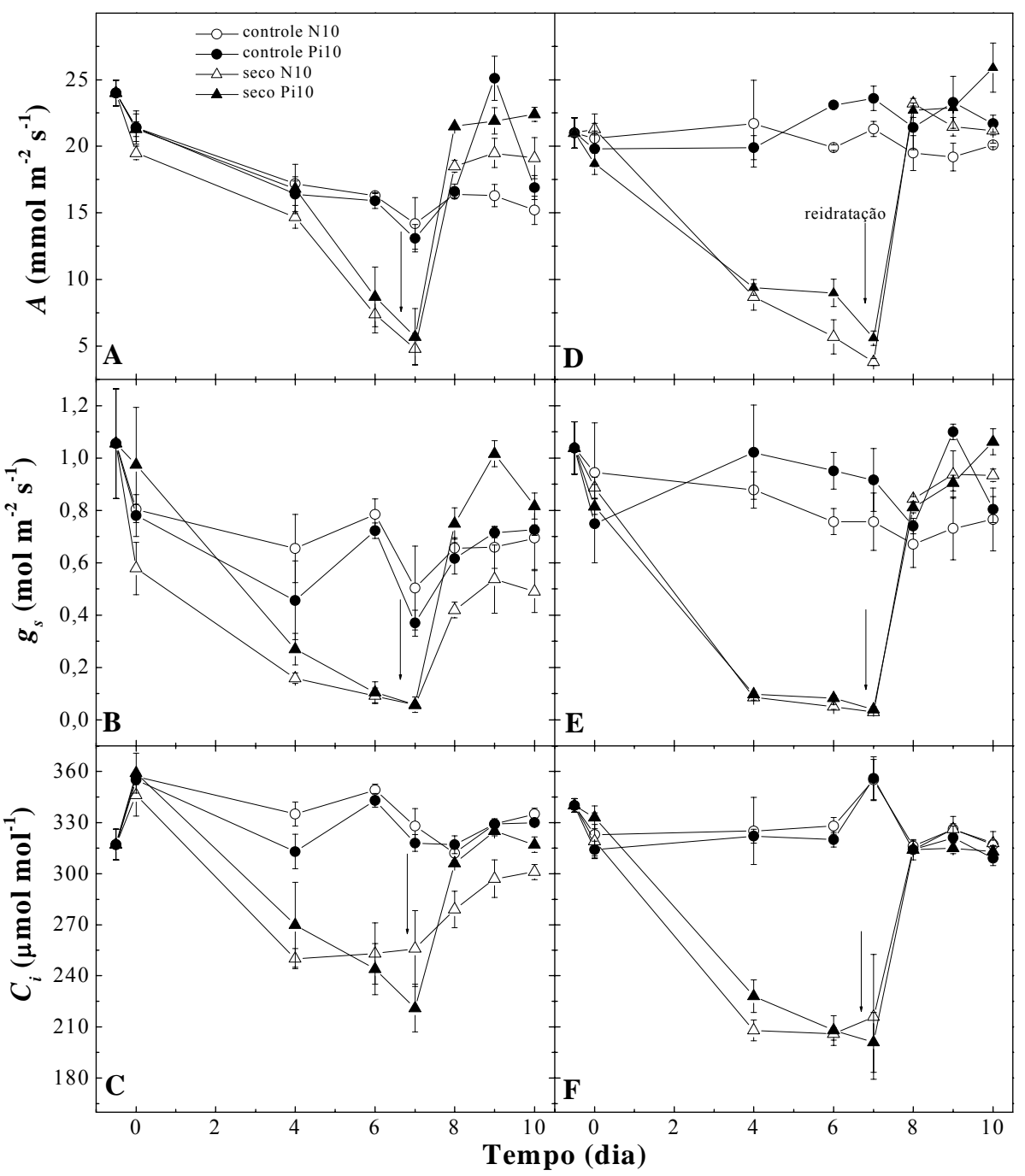

Figura 1 - Taxa de assimilação de $\mathrm{CO}_{2}\left(A\right.$ em A, D), condutância estomática $\left(g_{s} \mathrm{em} \mathrm{B,} \mathrm{E)}\right.$ e concentração de $\mathrm{CO}_{2}$ intercelular $\left(C_{i}\right.$ em $\left.\mathrm{C}, \mathrm{F}\right)$ dos genótipos de feijoeiro A320 (A, B, C) e Ouro Negro (D, E, F), sob déficit hídrico. As folhas foram pulverizadas com $10 \mathrm{~g} \mathrm{Pi} \mathrm{L}^{-1}$ (símbolos fechados) ou 2,64 $\mathrm{g} \mathrm{N} \mathrm{L}^{-1}$ (símbolos abertos) dois dias antes da suspensão da irrigação. As plantas foram reidratadas após sete dias de seca. A temperatura média diária variou de 23 a $26,6^{\circ} \mathrm{C}$. Cada ponto representa o valor médio \pm erro padrão $(n=3)$ 
Tabela 1. Liberação de $\mathrm{O}_{2}$ e potencial fotossintético $\left(\mu \mathrm{mol} \mathrm{m} \mathrm{m}^{-2} \mathrm{~s}^{-1}\right)(A c)$ de genótipos de feijoeiro A320 e Ouro Negro após sete dias de seca (máximo estresse) e após a reidratação (três dias após reidratar) em plantas pulverizadas com Pi foliar e não pulverizadas. As folhas supridas com Pi foram pulverizadas com $10 \mathrm{~g} \mathrm{P} \mathrm{L}^{-1}$ e as plantas sem Pi (controle) foram supridas com 2,64 $\mathrm{g} \mathrm{N} \mathrm{L}^{-1}$. Os valores são médias ( \pm e.p.) de três plantas

\begin{tabular}{|c|c|c|c|}
\hline \multirow{2}{*}{ Genótipo } & \multirow{2}{*}{ Pi foliar } & \multicolumn{2}{|c|}{ *Déficit hídrico } \\
\hline & & Máximo estresse & Após recuperação \\
\hline \multirow{2}{*}{ A320 } & sem Pi & $17,0 \mathrm{c}$ & $19,33 \mathrm{c}$ \\
\hline & com Pi & $18,55 \mathrm{c}$ & $26,97 \mathrm{ab}$ \\
\hline \multirow{3}{*}{ Ouro negro } & sem Pi & $21,45 \mathrm{bc}$ & $27,76 \mathrm{ab}$ \\
\hline & & & \\
\hline & com Pi & $26,08 \mathrm{ab}$ & $32,4 \mathrm{a}$ \\
\hline
\end{tabular}

\subsubsection{Deficiência hídrica, aplicação de Pi e fluorescência da clorofila}

O maquinário fotoquímico de ambos os genótipos foi relativamente tolerante ao déficit hídrico moderado. A eficiência quântica potencial $\left(\mathrm{F}_{\mathrm{v}} / \mathrm{F}_{\mathrm{m}}\right)$ e a efetiva $\left(\Delta \mathrm{F} / \mathrm{F}_{\mathrm{m}}{ }^{\prime}\right)$ do PSII não foram afetadas pela seca moderada ou pelo suprimento de Pi $(\mathrm{p}>0,05)$ (Dados não apresentados). A ETR também não foi afetada pelo suprimento foliar de Pi nos dois genótipos, no dia de máximo estresse e na recuperação (Tabela 2). Contudo, a dissipação não fotoquímica, a NPQ, do genótipo A320 sem Pi foi maior que com Pi e que a do Ouro negro, com e sem Pi, na reidratação. 
Tabela 2. Taxa aparente de transporte de elétrons $\left(\mu \mathrm{mol} \mathrm{m} \mathrm{m}^{-2} \mathrm{~s}^{-1}\right)$ (ETR) e coeficiente de extinção não-fotoquímica da fluorescência (NPQ),de genótipos de feijoeiro A320 e Ouro Negro, após sete dias de seca (máximo estresse) e após a reidratação (três dias após reidratar) em plantas pulverizadas com Pi foliar e não pulverizadas. As folhas supridas com Pi foram pulverizadas com $10 \mathrm{~g} \mathrm{P} \mathrm{L}^{-1}$ e as plantas sem Pi (controle) foram supridas com 2,64 $\mathrm{g} \mathrm{N} \mathrm{L}^{-1}$. Os valores são médias ( \pm e.p.) de três plantas

\begin{tabular}{|c|c|c|c|c|}
\hline \multirow{2}{*}{ Parâmetros } & \multirow{2}{*}{ Genótipo } & \multirow{2}{*}{ Pi foliar } & \multicolumn{2}{|c|}{ *Déficit hídrico } \\
\hline & & & Máximo estresse & Após a recuperação \\
\hline \multirow{4}{*}{ ETR } & \multirow{2}{*}{ A320 } & sem Pi & $293,48 a b$ & $279,83 \mathrm{ab}$ \\
\hline & & com $\mathrm{Pi}$ & $291,75 \mathrm{~b}$ & $295,83 \mathrm{ab}$ \\
\hline & \multirow{2}{*}{ Ouro Negro } & sem Pi & $309,02 \mathrm{ab}$ & $311,05 \mathrm{ab}$ \\
\hline & & com $\mathrm{Pi}$ & $320,79 \mathrm{a}$ & $318,74 \mathrm{ab}$ \\
\hline \multirow{4}{*}{ NPQ } & \multirow{2}{*}{ A 320} & sem Pi & $0,92 \mathrm{~b}$ & $1,10 \mathrm{a}$ \\
\hline & & com $\mathrm{Pi}$ & $0,89 \mathrm{~b}$ & $0,89 \mathrm{~b}$ \\
\hline & \multirow{2}{*}{ Ouro Negro } & sem Pi & $0,69 \mathrm{bc}$ & $0,79 \mathrm{~b}$ \\
\hline & & com $\mathrm{Pi}$ & $0,57 \mathrm{c}$ & $0,74 \mathrm{bc}$ \\
\hline
\end{tabular}

*Dados seguidos por letras diferentes apresentaram diferença estatística entre os tratamentos, pelo teste de Student Neuman Keul's $\mathrm{p}<0,05(\mathrm{n}=3)$.

\subsubsection{Efeito da seca e do suprimento de Pi sobre os componentes de produção}

Para os componentes de produção avaliados no final do ciclo das plantas, não houve diferença significativa quanto ao número de vagens e peso de sementes por planta, quando considerado o suprimento de Pi e a seca, em ambos os genótipos, apesar de uma tendência de maior peso de sementes do A320 e do Ouro Negro com Pi foliar, em relação ao controle também sob seca (Tabela 3). 
Tabela 3. Componentes de produção (número de vagens e peso de sementes por planta de genótipos de feijoeiro (A320 e Ouro Negro),. Submetidos ou não a sete dias de seca no estádio de polinização, com ou sem pulverização de Pi foliar. As folhas supridas com Pi foram pulverizadas com $10 \mathrm{~g} \mathrm{P} \mathrm{L}^{-1}$ e as plantas sem $\mathrm{Pi}$ (controle) foram supridas com 2,64 $\mathrm{g} \mathrm{N} \mathrm{L}^{-1}$. Os valores são médias ( \pm e.p.) de três plantas

\begin{tabular}{cccccc}
\hline \multirow{2}{*}{ Genótipo } & Pi foliar & \multicolumn{3}{c}{ Componentes da produção (por planta) } \\
& & número de vagens & peso de sementes (g) \\
& Controle & estressado & controle & estressado \\
\hline \multirow{2}{*}{ A320 } & sem Pi & $31 \mathrm{a}$ & $22 \mathrm{~b}$ & $17 \mathrm{ab}$ & $11 \mathrm{~b}$ \\
& com Pi & $23 \mathrm{~b}$ & $20 \mathrm{~b}$ & $15 \mathrm{ab}$ & $13 \mathrm{~b}$ \\
\multirow{2}{*}{ Ouro Negro } & sem Pi & $30 \mathrm{a}$ & $18 \mathrm{~b}$ & $23 \mathrm{a}$ & $13 \mathrm{~b}$ \\
& com Pi & $33 \mathrm{a}$ & $18 \mathrm{~b}$ & $18 \mathrm{ab}$ & $15 \mathrm{ab}$ \\
\hline
\end{tabular}

*Dados seguidos por letras diferentes mostraram diferença estatística entre os tratamentos com e sem Pi foliar e com e sem irrigação contínua pelo teste Student Neuman Keul's $p<0.05(n=3)$.

\subsection{Discussão}

Considerando as trocas gasosas durante o dessecamento (Figura 1), houve uma diminuição tanto de $A$ como de $g_{s}$ até o último dia de estresse, recuperando-se com a reidratação, principalmente para o tratamento com Pi em ambos os genótipos. A redução de $g_{s}$ pode ter sido uma causa da redução de $A$, de acordo com Sharkey \& Seemann (1989) e Chaves et al. (2002), pois este foi um estresse moderado. Contudo, pode-se notar que a $g_{s}$, principalmente de A320, decresceu mais drasticamente que $A$, quase se anulando já no quarto dia de seca (Figura 1B), enquanto $A$ ainda era alta neste dia (Figura 1A), o que pode significar um pequeno efeito do fechamento estomático sobre a fotossíntese sob seca, o que estaria de acordo com Lauer \& Boyer (1992) e Tang et al. (2002). Em Ouro negro, esta diferença de respostas de $A$ e de $g_{s}$ não foi tão acentuada, e este genótipo teve $A$ mais sensível à deficiência hídrica neste quarto dia de estresse.

Quanto aos efeitos do suprimento de Pi em plantas dessecadas, a possível falta de fósforo, devido ao solo seco (Mouat \& Nes, 1986), pode agravar os efeitos da 
deficiência hídrica sobre a fotossíntese (Hubhra et al., 2004). Apesar de não haver diferenças significativas entre os tratamentos com e sem Pi, em ambos os genótipos, sob desidratação, houve uma tendência dos valores de $A$ serem superiores nas plantas que receberam Pi foliar. Já na reidratação, ambos os genótipos apresentaram valores de $A$ superiores quando receberam Pi foliar, o que mostra um efeito metabólico dependente, pelo menos em parte, do suprimento de Pi citoplasmático (Hendrickson et al., 2004), na capacidade de recuperação das plantas após serem reidratadas. Este efeito benéfico do suprimento extra de Pi também permitiu A320 manter maiores valores de $g_{s}$ na reidratação, mas não para Ouro negro, o que mostra um efeito genotípico do Pi foliar.

Considerando os valores de $A c$, o efeito do suprimento foliar de Pi se torna evidente na reidratação dos dois genótipos (Tabela 1), quando não houve limitação estomática e da fotorrespiração (Delieu \& Walker, 1981). Estes resultados mostram que o conteúdo de Pi foliar pode ser um fator que limita o potencial fotossintético sob seca e, principalmente, na recuperação de plantas reidratadas de feijoeiro. As plantas do genótipo A320 não supridas com Pi tiveram baixos valores de $A c$ no máximo estresse, mas sem diferenças significativas do A320 com Pi, indicando uma possível limitação metabólica à fotossíntese causada pela seca (Lauer \& Boyer, 1992; Tang et al., 2002). Chaves et al. (2002) consideraram que o fechamento estomático é a resposta inicial ao déficit hídrico e a limitação dominante à fotossíntese, em uma seca moderada. Contudo, uma progressiva regulação ou inibição dos processos metabólicos torna-se dominante sob uma seca severa (Bota et al., 2004), que pode ser diminuída pelo suprimento extra de Pi. Considerando a inibição fotoquímica da fotossíntese, a taxa de síntese de produtos finais (sacarose, amido e aminoácidos) em folhas, determina a taxa na qual o Pi é reciclado de volta às reações da fotossíntese, limitando esta (Leegood, 1996). Além disso, Maleszewski et al. (2004) demonstram que a homeostase do Pi celular depende da taxa fotorrespiratória sob baixo conteúdo de $\mathrm{Pi}$, e assim, a fotorrespiração ajuda a manter a reciclagem de $\mathrm{Pi}$, aumentando a disponibilidade de Pi intracelular. Paul \& Pellny (2003) discutiram que este potencial mecanismo de reciclagem de Pi fotorrespiratório, diminuindo a inibição da fotossíntese, que pode ser observado quando o Pi está ausente do meio de crescimento das plantas (Pieters et al., 2001; Holbrook \& Keys, 2003). 
Assim, uma reduzida disponibilidade de Pi para o metabolismo vegetal sob déficit hídrico pode ser um fator de inibição para os tecidos fotossintetizantes. Hendrickson et al. (2004) mostraram o importante papel do Pi na fotossíntese em folhas de videira, quando estas foram supridas com uma solução de Pi via foliar, antes do início da imposição de um tratamento com baixa temperatura. Neste estudo, o suprimento com Pi causou um acentuado estímulo da liberação do $\mathrm{O}_{2}$, durante o estresse promovido por baixas temperaturas.

Quanto às reações fotoquímicas, a seca não causou mudanças substanciais nos parâmetros de fluorescência da clorofila $F_{v} / F_{m}$ e $\Delta F / F_{m}$ ', em ambos os genótipos (Dados não apresentados), o que caracteriza bem o estresse moderado por falta d'água. Esses resultados estão de acordo com Cornic \& Briantais (1991), os quais relataram que uma deficiência hídrica moderada não afetou significativamente a parte fotoquímica da fotossíntese. Como uma possível explicação, pode-se sugerir que o déficit hídrico abriu uma nova rota para utilização dos elétrons fotossintéticos com um outro receptor final que não o dióxido de carbono, i.e., como o oxigênio molecular (Havaux, 1992) ou o ciclo das xantofilas (Maxwell \& Johnson, 2000; von Caemmerer, 2000).

O fluxo de energia absorvida nos fotossistemas, promovendo o transporte de elétrons (avaliado pela ETR), não foi diferente entre os tratamentos com e sem Pi, nos dois genótipos, nem no último dia de seca nem na reidratação (Tabela 2). Bota et al. (2004) relataram que a ETR declina muito menos do que a assimilação de $\mathrm{CO}_{2}(A)$ sob déficit hídrico, devido um aumento progressivo da fotorrespiração, sob desidratação. Já o coeficiente de extinção não fotoquímica da fluorescência (NPQ), que representa tanto a dissipação de energia pelos sistemas antioxidantes como os danos causados nos fotossistemas, pelas espécies ativas de oxigênio formadas (von Caemmerer, 2000), foi diferente para os genótipos e para o suplemento de Pi foliar, principalmente na reidratação (Tabela 2). O genótipo A320 sem Pi apresentou os maiores valores de NPQ na recuperação, e o suprimento de $\mathrm{Pi}$ foliar neste genótipo diminui o NPQ. Provavelmente, este maior valor de NPQ, no A320 sem Pi na reidratação, foi devido a uma necessidade de maior dissipação térmica de energia absorvida, comparado às 
plantas com Pi e do genótipo Ouro Negro, pois a assimilação de $\mathrm{CO}_{2}$ (e o conseqüente consumo de ATP e $\mathrm{NADPH}_{2}$ ) de $\mathrm{A} 320$ sem Pi foi menor que com Pi, na reidratação.

Todavia, é importante considerar que qualquer mecanismo para evitar efeitos deletérios da seca é importante para a produção da cultura, especialmente quando o estresse ocorre em um estádio chave do ciclo da cultura para assegurar a produção. Isto porque a maioria das vagens (90\%) do feijoeiro, que alcança a maturação, são formadas a partir das flores iniciais e, assim, a redução da assimilação de $\mathrm{CO}_{2}$, induzida pelo déficit hídrico neste estádio, causará a abscisão de flores e uma menor produtividade (Norman et al., 1995). De fato, o pequeno aumento da taxa líquida fotossintética das plantas supridas com Pi, durante o período de recuperação (Figura 1A), foi importante para o componente de produção peso seco de semente do genótipo A320, que apesar de não haver diferença significativa, apresentou quase o dobro de peso de sementes, quando suprido com o Pi foliar (Tabela 1).

Quando comparamos os dados sobre as trocas gasosas, quanto à resposta aos estresses ambientais, pode se verificar grandes diferenças nas características entre os genótipos de feijoeiro (Pimentel et al., 1999a; Ribeiro et al., 2004). Os resultados do presente trabalho revelaram diferenças na resposta à seca devido à pulverização com $\mathrm{Pi}$, que suportam a hipótese que a fotossíntese do feijoeiro é afetada diferentemente sob déficit hídrico, dependendo do genótipo de feijoeiro; bem como a hipótese de um efeito positivo do suprimento extra de $\mathrm{Pi}$ foliar, antes da deficiência hídrica, sobre a fotossíntese de feijoeiro, mas que também é dependente do genótipo.

Em diversas áreas brasileiras produtoras de feijão, os solos têm um baixo nível de fósforo disponível, e estes recebem adubação fosfatada somente no plantio (Fageria et al., 2004). Assim, a aplicação foliar de fosfato monoamonio, substituindo a aplicação de sulfato de amônio ou uréia, que é feita aos 25 DAE (Vieira, 1998), poderia fornecer o suprimento extra de nitrogênio necessário, mas também um suprimento extra de fósforo, aumentando dessa forma, a tolerância aos efeitos negativos causados pela seca sobre o metabolismo fotossintético. Mais estudos são necessários para determinar a existência da limitação fotossintética pela baixa disponibilidade de Pi e da produção sob condições de campo. 


\section{CONCLUSÕES GERAIS}

O suprimento extra de fósforo, via foliar, quando aplicado antes do período de déficit hídrico no feijoeiro comum, demonstrou ser capaz de amenizar os efeitos negativos da seca. No presente estudo não se pôde constatar aumento de produção nas plantas supridas com Pi foliar e sob seca (somente no número de vagens), talvez devido às condições de crescimento em potes sob a casa de vegetação. Entretanto, a resposta das trocas gasosas estimula estudos futuros sob condições de campo, podendo-se chegar desse modo a uma tecnologia fitotécnica, através da qual um suprimento extra de Pi via foliar, na época da adubação de cobertura, ou seja, pouco antes da pré-floração, promoveria uma maior tolerância à falta de água, durante os estádios seguintes de floração e enchimento das vagens, dessa espécie sensível à deficiência hídrica e pobre extratora de fósforo. De qualquer forma, uma recomendação que pode ser feita, baseada no presente estudo, é que a adubação de nitrogênio em cobertura, indicada aos $25 \mathrm{DAE}$, seja feita com fosfato de amônio, ao invés de sulfato de amônio ou uréia, como feita tradicionalmente. 


\section{REFERÊNCIAS BIBLIOGRÁFICAS}

ABEL, S.; TICCONI, C.A.; DELATORRE, C.A. Phosphate sensing in higher plants. Physiologia Plantarum, v.115, p.1-8, 2002.

ALAM, S.M. Nutrient uptake by plants under stress conditions. In: PESSARAKLI, M. (Ed.). Handbook of plant and crop stress. New York: Marcel Dekker, 1999. p.285313.

ANWARUZZAMAN; SAWADA, S.; USUDA, H.; YOKOTA, A. Regulation of ribulose 1,5-bisphosphate carboxylase/oxygenase activation by inorganic phosphate through stimulating the binding of the activator $\mathrm{CO}_{2}$ to the activation sites. Plant Cell Physiology, v.36, p.425-433, 1995.

ARAÚJO, A.P.; TEIXEIRA, M.G. Nitrogen and phosphorus harvest indices of common bean cultivars: implications for yield quantity and quality. Plant and Soil, v.257, p.425-433, 2003.

ARAÚJO, A.P.; TEIXEIRA, M.G.; ALMEIDA, D.L. Variability of traits associated with phosphorus efficiency in wild and cultivated genotypes of common bean. Plant and Soil, v.203, p.173-182, 1998.

BARRETO, A.C.; SERPA, J.E.S. O fósforo na produção de milho e de feijão em monocultivo e em consórcio. Pesquisa Agropecuária Brasileira, v.23, p.10731081, 1988.

BASCUR, G.; OLIVA, M.A.; LAING, D. Termometria infraroja en selection de genotipos de Frijol (Phaseolus vulgaris L.), resistentes a sequia. I Bases fisiológicas; II. Crecimento y productividade. Turrialba, v.35, p.3-33, 1985. 
BORÉM, A.; CARNEIRO, J.E.S. A cultura. In.: VIEIRA, C.; PAULA JUNIOR, T.J.de.; BORÉM, A. (Ed.). Feijão aspectos gerais e cultura no Estado de Minas. Viçosa: UFV, 1998. p.13-17.

BOTA, J.; MEDRANO, H.; FLEXAS, J. Is photosynthesis limited by decreased Rubisco activity and RuBP content under progressive water stress? New Phytologist, v.162, p.671-681, 2004.

BOUTRAA, T.; SANDERS, F.E. Influence of water stress on grain yield and vegetative growth of two cultivars of bean (Phaseolus vulgaris L.). Journal of Agronomy and Crop Science, v.187, p.251-257, 2001.

BOYER, J.S. Water deficit and photosynthesis. In: KOZLOWSKI, T.T. (Ed.). Water deficits and plant growth. London: Academic Press, 1978, v.4, p.154-191.

BOYER, J.S. Subcellular mechanisms of plant response to low water potential. Agriculture Eater Manage, v.7, p.239-248, 1983.

CENTRO INTERNACIONAL DE AGRICULTURA TROPICAL - CIAT. Programa de frijol. Informe Anual, Cali, Co, 1987. 383p.

CHAVES, M.M. Effects of water deficit on carbon assimilation. Journal of Experimental Botany, v.42, p.1-16, 1991.

CHAVES, M.M.; OLIVEIRA, M.M. Mechanisms underlying plant resilience to water deficits: prospects for water-saving agriculture. Journal of Experimental Botany, v.55, p.2365-2384, 2004.

CHAVES, M.M.; PEREIRA, J.S.; MAROCO, J.; RODRIGUES, M.L.; RICARDO, C.P.P.; OSÓRIO, M.L.; CARVALHO, I.; FARIA, T.; PINHEIRO, C. How plants cope with water stress in the field: photosynthesis and growth. Annals of Botany, v.89, p.907-916, 2002.

COMPANHIA NACIONAL DE ABASTECIMETO - CONAB, 2004. Disponível em: www.conab.gov.br. (15/09/2004).

COMSTOCK, J.; EHLERINGER, J.R. Stomatal response to humidity in common bean (Phaseolus vulgaris L): Implications for maximum transpiration rate, water-use efficiency and productivity. Australian Journal of Plant Physiology, v.20, p.669$691,1993$. 
CONDON, A.G.; RICHARDS, R.A.; REBELZKE, G.J.; FARQUHAR, G.D. Breeding for high water-use efficency. Journal of Experimental Botany, v.55, p.2447-2460, 2004.

CORNIC, G.; BRIANTAIS, J.M. Partitioning of photosynthetic electron flow between $\mathrm{CO}_{2}$ and $\mathrm{O}_{2}$ reduction in a $\mathrm{C}_{3}$ leaf (Phaseolus vulgaris L.) at different $\mathrm{CO}_{2}$ concentrations and during drought stress. Planta, v.183, p.178-184, 1991.

CORREIA, M.J.; PEREIRA, J.S. The control of leaf conductance of white lupin by xylem ABA concentration decreases with the severity of water deficits. Journal of Experimental Botany, v.46, p.101-110, 1995.

DE GROOT, C.C.; VAN DEN BOOGAARD, R.; MARCELIS, L.F.M.; HARBINSON, J.; LAMBERS, H. Contrasting effects of $\mathrm{N}$ and $\mathrm{P}$ deprivation on the regulation of photosynthesis in tomato plants in relation to feedback limitation. Journal of Experimental Botany, v.54, p.1957-1967, 2002.

DELIEU, T.; WALKER, D.A. Polarographic measurement of photosynthetic oxygen evolution by leaf discs. New Phytologist, v.89, p.165-178, 1981.

DIETZ, K.J.; FOYER, C. The relationship between phosphate status and photosynthesis in leaves. Planta, v.167, p.376-381, 1986.

EHLERINGER, J.R. Correlations between carbon isotope discrimination and leaf conductance to water vapor in common beans. Plant Physiology, v.93, p.1422-1425, 1990

FAGERIA, N.K.; BALLIGAR, V.C.; JONES, C.A. Growth and mineral nutrition of field crops. New York: Marcel Dekker, 1997. p.441-489.

FAGERIA, N.K.; BARBOSA-FILHO, M.P.; STONE, L.F. Nutrição de fósforo na produção de feijoeiro. In: YAMADA, T., ABDALLA, S.R.S. (Ed.). Fósforo na agricultura brasileira, Piracicaba: Potafos, 2004. p.435-455.

FERNANDEZ, D.S.; ASCENCIO, J. Acid phosphatase activity in bean and cowpea plants grown under phosphorus stress. Journal of Plant Nutrition, v.17, p.229-241, 1994. 
FLEXAS, J.; MEDRANO, H. Drought-inhibition of photosynthesis in $\mathrm{C}_{3}$ plants: stomatal and non-stomatal limitations revisited. Annals of Botany, v.89, p.183-189, 2002.

FLIEGE, R.; FLÜGGE, U.I.; WERDAN, K.; HELDT, H.W. Specific transport of inorganic phosphate, 3-phosphoglycerate and triosephosphates across the inner membrane of the envelope in spinach chloroplasts. Biochimica et Biophysica Acta, v.502, p.232-247, 1978.

FLÜGGE, U.I. Phosphate translocation in the regulation of photosynthesis. Journal of Experimental Botany, v.46, p.1317-1323, 1995.

FLÜGGE, U.I.; HÄUSLER, R.E.; LUDEWIG, F.; FISCHER, K. Functional genomics of phosphate antiport systems of plastids. Physiologia Plantarum, v.118, p.475-482, 2003.

FÖSE, D.; CLASSEN, N.; JUNGK, A. Phosphorus efficiency of plants. Plant and Soil, v.110, p.101-109, 1988.

GENTY, B.; BRIANTAIS, J.M.; BAKER, N.R. The relationship between the quantum yield of photosynthetic electron transport and quenching of chlorophyll fluorescence. Biochimica et Biophysica Acta, v.990, p.87-92, 1989.

GERHARDT, R.; STITT, M.; HELDT, H.W. Subcellular metabolite levels in spinach leaves. Regulation of sucrose synthesis during diurnal alterations in photosynthetic partitioning. Plant Physiology, v.83, p.399-407, 1987.

GROSSMAN, A.; TAKAHASHI, H. Macronutrient utilization by photosynthetic eukaryotes and the fabric of interactions. Annual Review of Plant Physiology and Plant Mololecular Biology, v.52, p.163-210, 2001.

GUIMARÃES, C.M.; BRUNINI, O.; STONE, L.F. Adaptação do feijoeiro (Phaseolus vulgaris L.) à seca 1. Densidade e eficiência radicular. Pesquisa Agropecuária Brasileira, v.31, p.393-399, 1996a.

GUIMARÃES, C.M.; STONE, L.F.; BRUNINI, O. Adaptação do feijoeiro (Phaseolus vulgaris L.) à seca 11. Produtividade e componentes agronômicos. Pesquisa Agropecuária Brasileira, v.31, p.481-488, 1996 b. 
HALL, D.O.; RAO, K.K. Photosynthesis. Cambridge: Cambridge University Press, 1994. $221 \mathrm{p}$.

HALTERLEIN, A.J. Bean. In: TEARE, I.D.; PEET, M.M. Crop-water relations. New York: 1983, p.157-185.

HAVAUX, M. Stress tolerance of photosystem II in vivo. Antagonistic effects of water, heat, and photoinhibition stresses. Plant Physiology, v.100, p.424-432, 1992.

HENDRICKSON, L.; CHOW, W.S.; FURBANK, R.T. Low temperature effects on grapevine photosynthesis: the role of inorganic phosphate. Functional Plant Biology, v.31, p.789-801, 2004.

HOLBROOK, G.P.; KEYS, A.J. Evidence for recycling of inorganic phosphate by wheat chloroplasts during photosynthesis at air levels of $\mathrm{CO}_{2}$ and $\mathrm{O}_{2}$ Journal of Plant Physiology, v.160, p.1351-1360, 2003.

HOLBROOK, G.P.; KEYS, A.J. Evidence for recycling of inorganic phosphate by wheat chloroplasts during photosynthesis at air levels of $\mathrm{CO}_{2}$ and $\mathrm{O}_{2}$ Journal of Plant Physiology, v.160, p.1351-1360, 2003.

HSIAO, T.C. Mensuraments of plant water status. In: STEWART, B.A.; NIELSEN, D.R. (Ed.). Irrigation of agricultural crops. Madison: Marcel Dekker, 1990, p.244-279.

HSIAO, T.C.; ACEVEDO, E.A. Plant responses to water deficit, water-use efficiency, and drought resistence. Agricultural Meteorology, v.14, p.59-84, 1974.

HUBHRA, S.; DAYAL, J.; GOSWAMI, C.L.; MUNJAL, R. Influence of phosphorus application on water relations, biochemical parameters and gum content in cluster bean under water deficit. Biologia Plantarum, v.48, p.445-448, 2004.

JONES, H.G. Partitioning stomatal and non-stomatal limitation to photosynthesis. Plant, Cell and Environment, v.8, p.95-104, 1985.

KONDRACKA, A.; RYCHTER, A.M. The role of Pi recycling processes during photosynthesis in phosphate-deficient bean plants. Journal of Experimental Botany, v.48, p.1461-1468, 1997.

KOZLOWSKA-SZERENOS, B.; BIALUK, I.; MALESZEWSKI, S. Enhancement of photosynthetic $\mathrm{O}_{2}$ evolution in Chlorella vulgaris under high light and increased 
$\mathrm{CO}_{2}$ concentration as a sign of acclimation to phosphate deficiency. Plant Physiology and Biochemistry, v.42, p.403-409, 2004.

KRAMER, P.J.; BOYER, J.S. Water relations of plants and soils. San Diego: Academic Press, 1995. 485p.

KURUVADI, S.; AGUILERA, D.M. Patrones del sistema radical en frijol común (Phaseolus vulgaris L). Turrialba, v.40, p.491-498, 1990.

LAFFRAY, D.; LOUGUET, P. Stomatal responses and drought resistance. Actual Botany, v.1, p.47-60, 1990.

LAUER, M.J.; BLEVINS, D.; SIERZPUTOWSKA-GRACZ, H. ${ }^{32} \mathrm{P}-$ Nuclear magnetic resonance determination of phosphate compartmentation in leaves of reproductive soybeans (Glycine max L.) as affected by phosphate nutrition. Plant Physiology, v.89, p.1331-1336, 1989.

LAUER, M.J.; BOYER, J.S. Internal $\mathrm{CO}_{2}$ measured directly in leaves. Plant Physiology, v.98, p.1310-1316, 1992.

LAWLOR, D.W.; CORNIC, G. Photosynthetic carbon assimilation and associated metabolism in relation to water deficits in higher plants. Plant, Cell and Environment, v.25, p.275-294, 2002.

LEE, R.B.; RATCLIFFE, R.G.; SOUTHON, T.E. Subcellular distribution of inorganic phosphate, and levels of nucleoside triphosphate, in mature maize roots at low external phosphate concentrations: measurements with ${ }^{31} \mathrm{P}$ NMR. Journal of Experimental Botany, v.44, p.587-598, 1993.

LEEGOOD, R.C. Primary photosynthate production: physiology and metabolism. In: ZAMSKI, E.; SCHAFFER, A.A. (Ed.). Photoassimilate distribution in plants and crops. Source -sink relationships. New York: Marcel Dekker, 1996. p.21-42.

LEEGOOD, R.C.; FURBANK, R.T. Stimulation of photosynthesis by $2 \%$ oxygen at low temperatures is restored by phosphate. Planta, v.168, p.84-93, 1986.

LOPES, N.F.; OLIVA, M.A.; CARDOSO, M.J.; GOMES, M.M.S.; SOUZA, V.F. Crescimento e conversão de energia solar em Phaseolus vulgaris L., submetido a três densidades de fluxo radiante e dois regimes hídricos. Revista Ceres, v.33, p.142-164, 1986. 
MAGALHÃES, A.A.; DEMILLAR, A.A. Efeito de déficit de água no período reprodutivo sobre a produção de feijão. Pesquisa Agropecuária Brasileira, v.13, p.55-60, 1978.

MAGALHÃES, A.A.; MILLAR, A.A. Efeito de déficit de água no período reprodutivo sobre a produção de feijão. Pesquisa Agropecuária Brasileira, v.13, p.55-60, 1978.

MALAKONDAIAH, N.; RAJESWARARAO, G. Effect of foliar application of phosphorus on growth and mineral composition in peanut plants (Arachis hypogaea L.) under salt-stress. Plant and Soil, v.52, p.41-48, 1979.

MALAVOLTA, E.; VITTI, G.C.; OLIVEIRA, S.A. Metodologia para análise de elementos em material vegetal. In: MALAVOLTA, E.; VITTI, G.C.; OLIVEIRA, S.A. (Ed.). Avaliação do estado nutricional das plantas princípios e aplicações. Piracicaba: Potafos, 1997, p.231-305.

MALESZEWSKI, S.; CIERESZKO, I.; SKOWRONSKA, A.; MIECZEJKO, E. Changes induced by low oxygen concentration in photosynthetic and respiratory $\mathrm{CO}_{2}$ exchange in phosphate-deficient bean leaves. Biologia Plantarum, v.48, p.401405, 2004.

MASSONNEAU, A.; MARTINOIA, E.; DIETZ, K.J.; MIMURA, T. Phosphate uptake across the tonoplast of intact vacuoles isolated from suspension-cultured cells of Catharanthus roseus (L.) G. Don. Planta, v.211, p.390-395, 2000.

MAXWELL, K.; JOHNSON, G.N. Chlorophyll fluorescence - a practical guide. Journal of Experimental Botany, v.51, p.659-668, 2000.

McCREE, K.J. Measuring the whole-plant daily carbon balance. Photosynthetica, v.20, p.82-93, 1986.

MIMURA, T. Physiological control of phosphate uptake and phosphate homeostasis in plant cells. Australian Journal of Plant Physiology, v.28, p.653-658, 2001.

MOUAT, M.C.H.; NES, P. Influence of soil water content on the supply of phosphate to plants. Australian Journal of Soil Research, v.24, p.435-440, 1986.

NORMAN, M.J.T., PEARSON, C.J.; SEARLE, P.G.E. Common bean (Phaseolus vulgaris). In: NORMAN, M.J.T.; PEARSON, C.J.; SEARLE, P.G.E. (Eds.) The 
ecology of tropical food crops. Cambridge: Cambridge University Press, 1995, p.208-225.

NORMAN, M.J.T.; PEARSON, C.J.; SEARLE, P.G.E. The ecology of tropical food crops. Cambridge: Cambridge University Press, 1995, p.208-224.

NOVAIS, R.F.; SMYTH, T.J. Condições do fósforo no solo e planta em ambientes tropicais. Viçosa: Editora UFV, 1999, p.1-7.

ORTIZ-LÓPEZ, A.; ORT, D.R.; BOYER, J.S. Photophosphorylation in attached leaves of Helianthus annuus at low water potentials. Plant Physiology, v.96, p.1018-1025, 1991.

OSMOND, C.; ZIEGLER, H. Physiological plant ecology II. In: OSMOND, C.; ZIEGLER, H.WATER (Ed.). Relations and carbon assimilation,. New York: Verlag Berlin Heidelberg, 1980. p.5-33.

OSMOND, C.B.; WINTER, K.; POWLES, S.B. Adaptive significance of carbon dioxide cycling during photosynthesis in water-stressed plants. In: TURNER NC; KRAMER PJ (Eds.) Adaptation of plants to water and high temperature stress. New York: 1980, p.139-154.

O'TOOLE, J.C.; OZBUN, J.L.; WALLACE, D.H. Photosynthetic response to water stress in Phaseolus vulgaris L. Physiologia Plantarum, v.40, p.111-114, 1977.

PARRA, C.; MARTÍNEZ-BARAJAS, E.; ACOSTA, J.; COELHO, P. Phosphate deficiency responses of bean genotypes contrasting in their efficiency capacity to grow in low-phosphorus soils. Agrociência, v.38, p.131-139, 2004.

PASSIOURA, J.B. Drought and drought tolerance. In: BELHASSEN, E. (Ed.). Drought tolerance in higher plants: genetical, physiological and molecular biological analysis. Dordrecht: Kluwer Academic Publishers, 1997. p.1-6.

PAUL, M.J.; PELLNY, T.K. Carbon metabolite feedback regulation of leaf photosynthesis and development. Journal of Experimental Botany, v.54, p.539547, 2003.

PIETERS, A.J.; PAUL, M.J.; LAWLOR, D.W. Low sink demand limits photosynthesis under Pi deficiency. Journal of Experimental Botany, v.52, p.1083-1091, 2001. 
PIMENTEL, C. Balanço de carbono e os fatores ambientais. In: PIMENTEL, C. (Ed.) Metabolismo de carbono na agricultura tropical. Seropédica: Edur, 1998, p.103114.

PIMENTEL, C.; PEREZ, A.J.C. Estabelecimento de parâmetros para avaliação de tolerância a seca, em genótipos de feijoeiro. Pesquisa Agropecuária. Brasileira, V.35, p.31- 39, 2000.

PIMENTEL, C.; LAFFRAY, D.; LOUGUET, P. Intrinsic water use efficiency at the pollination stage as a parameter for drought tolerance selection in Phaseolus vulgaris. Physiologia Plantarum, v.106, p.184-198, 1999a.

PIMENTEL, C.; HEBERT, G.; VIEIRA DA SILVA, J. Effects of drought on O2 evolution and stomatal conductance of beans at the pollination stage. Environmental and Experimental Botany, v.42, p.155-162, $1999 \mathrm{~b}$.

PIMENTEL, C.; JACOB NETO, J.; GOI, S.R.; PESSANHA, G.G. Efeito do estresse hídrico em cultivares de Phaseolus vulgaris L., em simbiose com o Rhizobium leguminosarum biovar phaseoli. Turrialba, v.40, p.521-526, 1990.

PORTES, T. A. Ecofisiologia. In: ARAÚJO, R.S.; RAVA, C.A.; STONE, L.F.; ZIMMERMANN, M.J.O. (Ed.). Cultura do feijoeiro comum no Brasil. Piracicaba, Potafos: 1996. p.101-137.

RAGHOTHAMA, K.G. Phosphate acquisition. Annual Review of Plant Physiology and Plant Molecular Biology, v.50, p.665-693, 1999.

RAIJ, B.VAN.; CANTARELlA, H.; QUAGGIO, J.A.; FURLANI, A.M.C. Recomendações de adubação e calagem para o Estado de São Paulo. 2.ed. atual. Campinas: Instituto Agronômico; Fundação IAC, 1997, p.194-195.

RIBEIRO, R.V.; SANTOS, M.G.; SOUZA, G.M.; MACHADO, E.C.; OLIVEIRA, R.F.; ANGELOCCI, L.R.; PIMENTEL, C. Environmental effects on photosynthetic capacity of bean genotypes. Pesquisa Agropecuária Brasileira, v.39, p.615-625, 2004.

ROSALES-SERNA, R.; SHIBATA, J.K.; GALLEGOS, J.A.A.; LÓPEZ, C.T.; CERECERES, J.O.; KELLY, J.D. Biomass distribution, maturity acceleration and 
yield in drought-stressed common bean cultivars. Field Crops Research, v.85, p.203-211, 2004.

RYCHTER, A.M.; MIKULSKA, M. The relationship between phosphate status and cyanide-resistant respiration in bean roots. Physiologia Plantarum, v.79, p.663-667, 1990.

SAWADA, S.; USUDA, H.; HASEGAWA, Y.T.S.; UKUI, T. Regulation of ribulose1,5-bisphosphate carboxylase activity in response to changes in the source/sink balance in single-rooted soybean leaves: The role of inorganic orthophosphate in activation of the enzyme. Plant Cell Physiology, v.31, p.697-704, 1990.

SCHACHTMAN, D.P.; REID, R.J.; AYLING, S.M. Phosphorus uptake by plants: from soil to cell. Plant Physiology, v.116, p.447-453, 1998.

SCHREIBER, U. Detection of rapid induction kinetics with a new type of highfrequency modulated chlorophyll fluorometer. Photosynthesis Research, v.9, p.261-272, 1986.

SCHREIBER, U.; BILGER, W.; NEUBAUER, C. Chlorophyll fluorescence as a nonintrusive indicator for rapid assessment of in vivo photosynthesis. In: SCHULZE, E.D., CALDWELL, M.M. (Ed.). Ecophysiology of Photosynthesis. Ecological Studies. Berlin: Springer, 1994, p. 49-70.

SCHULZE, E.D. Carbon dioxide and water vapor exchange in response to drought in the atmosphere and in the soil. Annual Review of Plant Physiology, v.37, p.247274, 1986.

SCHUSSLER, J.R.; WESTGATE, M.E. Assimilate flux determines kernel set at low water potential. Crop Science, v.34, p.1569-1576, 1995.

SHARKEY, T.D.; SEEMANN, J.R. Mild water stress effects on carbon-reduction-cycle intermediates, ribulose bisphosphate carboxylase activity, and spatial homogeneity of photosynthesis in intact leaves. Plant Physiology, v.89, p.1060-1065, 1989.

SILVEIRA, P.M.; MOREIRA, J.A.A. Resposta do feijoeiro a doses de fósforo e lâminas de água de irrigação. Revista Brasileira de Ciência do Solo, v.14, p.63-67, 1990.

SINGH, S.P. Selection for water-stress tolerance in interracial populations of common bean. Crop Science, v.35, p.118-124, 1995. 
SINGH, S.P. Selection for water-stress tolerance in interracial populations of common bean. Crop Science, v.35, p.118-124, 1995.

SIVAK, M.N.; WALKER, D.A. Photosynthesis in vivo can be limited by phosphate supply. New Phytologist, v.102, p.499-512, 1986.

STITT, M.; QUICK, W.P. Photosynthetic carbon partitioning: its regulation and possibilities for manipulation. Physiologia Plantarum, v.77, p.633-641, 1989.

SUBBARAO, G.V.; JOHANSEN A.C.; SLINKARD, R.C.; RAO, N.; SAXENA, N.P.; CHAUHAN, Y.S. Strategies for improving drought resistance in grain legumes. Critical Reviews in Plant Sciences, v.14, p.469-523, 1995.

TANG, A.C.; KAWAMITSU, Y.; KANECHI, M.; BOYER, J.S. Photosynthetic oxygen evolution at low water potential in leaf discs lacking an epidermis. Annals of Botany, v.89, p.861-870, 2002.

TARDIEU, F. Drought perception by plants. Do cells of droughted plants experienc water stress. In: BELHASSEN, E. (Ed.). Drought tolerance in higher plants: genetical, physiological and molecular biological analysis. Dordrecht: Kluwer Academic Publishers, 1997, p.15-26.

TARDIEU, F.; SIMONNEAU, T. Variability among species of stomatal control under fluctuating soil water status and evaporative demand: modelling isohydric and anisohydric behaviours. Journal of Experimental Botany, v.49, p.419-432, 1998.

TEIXEIRA, M.G.; ARAÚJO, A.P. Aumento do teor de fósforo em sementes de feijoeiro através da adubação foliar. In: REUNIÃO NACIONAL DE PESQUISA DE FEIJÃO, 6., Salvador: Resumos expandidos. Arroz e Feijão. Santo Antônio de Goiás EMBRAPA: 1999, p.756-759.

TEZARA, W.; MITCHELL, V.J.; DRISCOLL, S.D.; LAWLOR, D.W. Water stress inhibits plant photosynthesis by decreasing coupling factor and ATP. Nature, v.401, p.914-917, 1999.

THORNE, G.N. Factors affecting uptake of radioactive phosphorus by leaves and its translocation to other parts of the plant. Annals of Botany, v.22, p.381-398, 1958.

TURNER, N.C. Adaptation to water deficits: a changing perspective. Australian Journal of Plant Phisiology, v.43, p.175-190, 1986. 
VASSEY, T.L.; QUICK, W.P.; SHARKEY, T.D.; STIT, M. Water stress, carbon dioxide, and light effects on sucrose-phosphate synthase activity in Phaseolus vulgaris. Physiologia Plantarum, v.81, p.37-44, 1991.

VICENTE, J.R.; ALMEIDA, L.A.; GONÇALVES, J.S.; SOUZA, S.A.M. Impactos da geração de tecnologia pela pesquisa paulista: o caso do feijão Carioca. Agricultura São Paulo, v.47, p.41-51, 2000.

VIEIRA, C. Adubação mineral e calagem. In: VIEIRA, C., DE PAULA JÚNIOR, T.J., BORÉM, A. (Ed.). Feijão: aspectos gerais e cultura no Estado de Minas Gerais. Viçosa: Editora UFV, 1998. p.123-152.

von CAEMMERER. Biochemical models of leaf photosynthesis. Techniques in Plant Sciences. No 2. CSIRO, Collingwood, Australia, 2000, p. 150.

WARDLAW, I.F. The control of carbon partioning in plants. New Phytologist, v.116, p.341-381, 1990.

WESTGATE, M.E.; BOYER, J.S. Reproduction at low sink and pollen water potentials in maize. Crop Science, v.26, p.951-956, 1986.

WISSUWA, M. How do plants achieve tolerance to phosphorus deficiency? Small causes with big effects. Plant Physiology, v.33, p.1947-1958, 2003.

YAN, X.; BEEBE, S.E.; LYNCH, J.P. Genetic variation for phosphorus efficiency of common bean in contrasting soil types: II. Yield response. Crop Science, v.35, p.1094-1099, 1995.

YAN, X.; LYNCH, J.P.; BEEBE, S.E. Utilization of phosphorus substrates by contrasting common bean genotypes. Crop Science, v.36, p.936-941, 1996.

YOKOYAMA, L.P.; BANNO, K.; KLUTHCOUSKI, J. Aspectos socioeconômicos da cultura. In: ARAÚJO, R.S.; RAVA, C.A.; STONE, L.F.; ZIMMERMANN, M.J.O. (Ed.). Cultura do feijoeiro comum no Brasil. Piracicaba: Potafos, 1996. p.139-167. YORDANOV, I.; VELIKOVA, V.; TSONEV, T. Plant response to drought, acclimation, and stress tolerance. Photosynthetica, v.38, p.171- 186, 2000.

ZIMMERMANN, M.J.O.;TEIXEIRA, M.G. Origem e evolução. In: ARAÚJO, R.S.; RAVA, C.A.; STONE, L.F.; ZIMMERMANN, M.J.O. (Ed.). Cultura do feijoeiro comum no Brasil. Piracicaba: Potafos, 1996. p.57-70. 